\title{
Synthesis of a Coumarin-based Analogue of
}

\section{Schweinfurthin F}

\author{
Chloe M. Schroeder, ${ }^{\mathrm{a}}$ Patrick N. Dey, ${ }^{\mathrm{a}}$ John A. Beutler ${ }^{\mathrm{b}}$ and David F. Wiemer ${ }^{\mathrm{a} *}$ \\ ${ }^{a}$ Department of Chemistry University of Iowa, Iowa City, Iowa 52242-1294 \\ ${ }^{\mathrm{b}}$ Molecular Targets Laboratory, Center for Cancer Research, NCI-Frederick, \\ Frederick, MD 21702 \\ david-wiemer@uiowa.edu
}

Table of Contents

$400 \mathrm{MHz}{ }^{1} \mathrm{H}$ NMR spectrum of 23 in $\mathrm{D}_{3} \mathrm{CC}(\mathrm{O}) \mathrm{CD}_{3}$

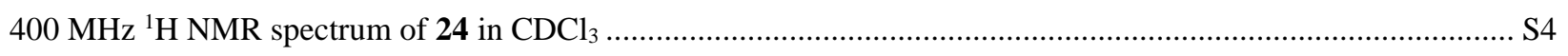

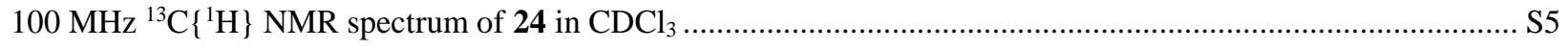

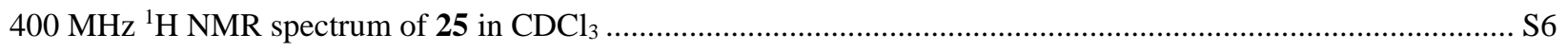

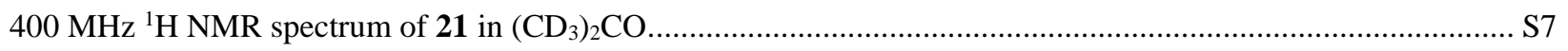

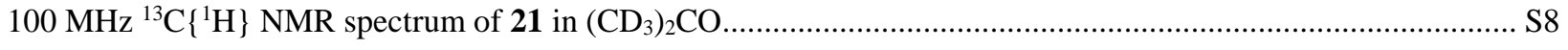

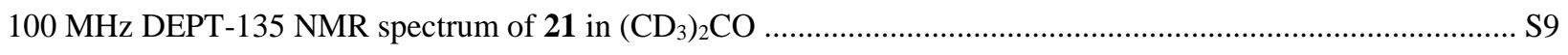

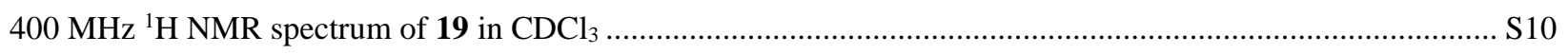

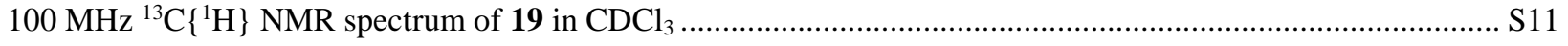

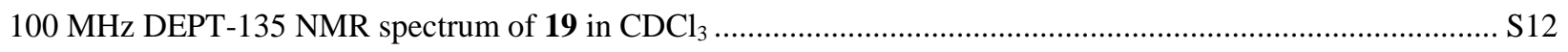

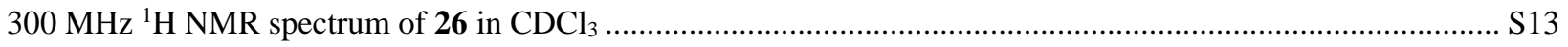

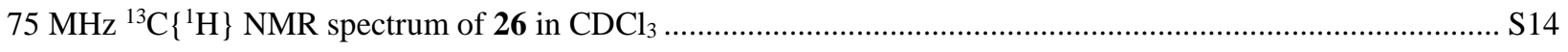

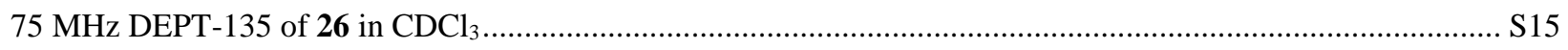

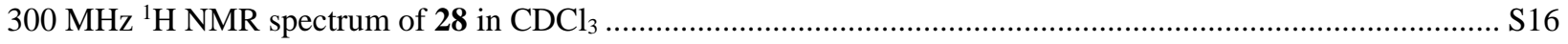

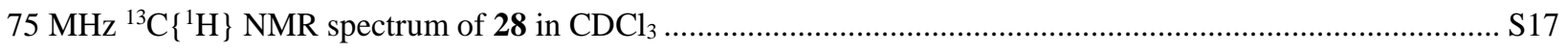

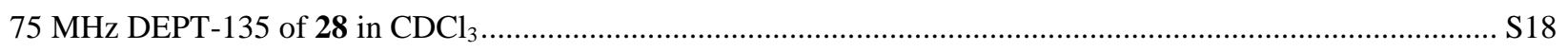

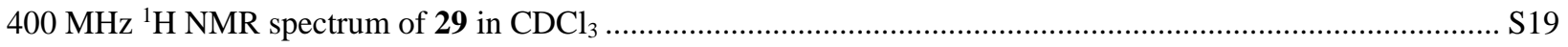

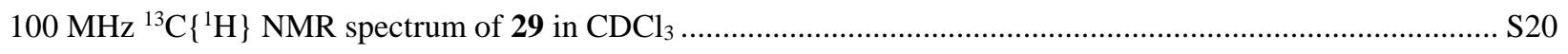

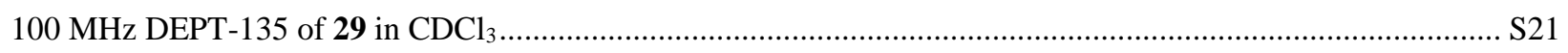

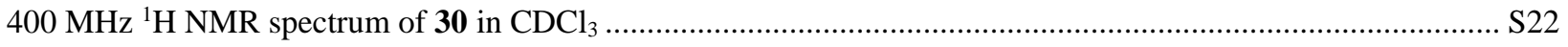

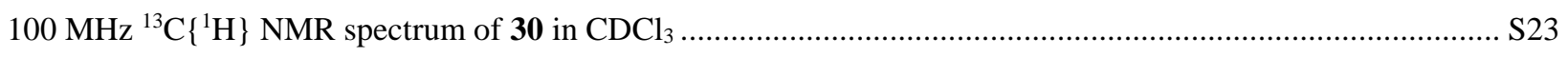

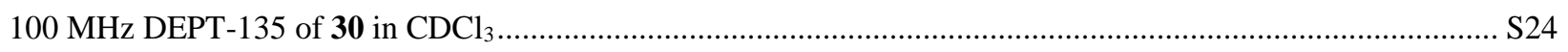




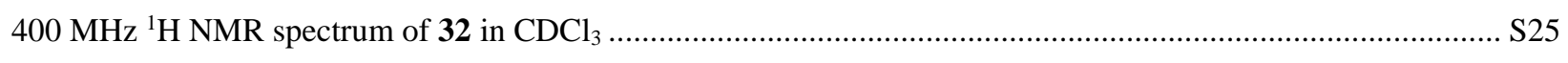

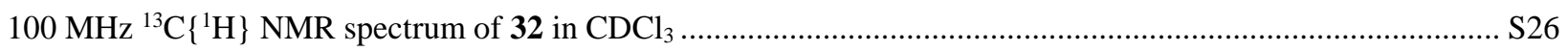

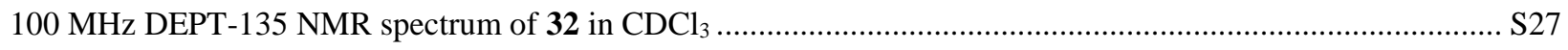

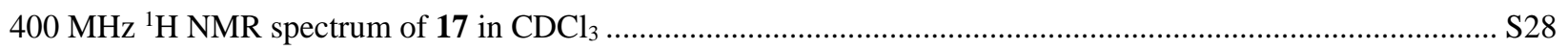

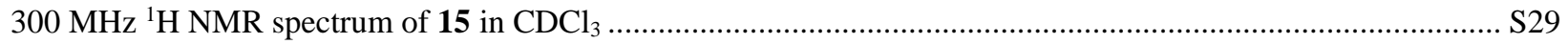

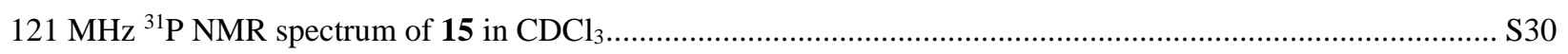

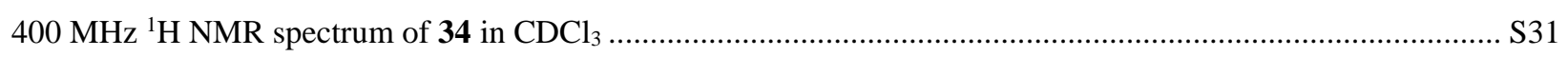

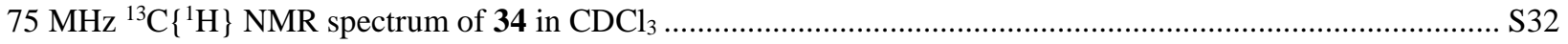

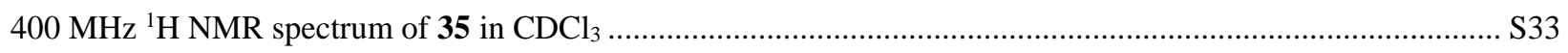

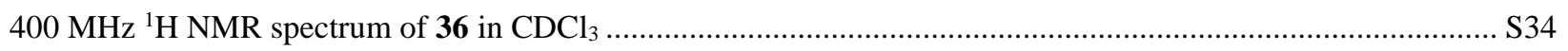

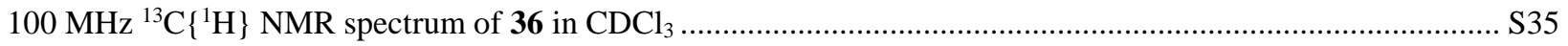

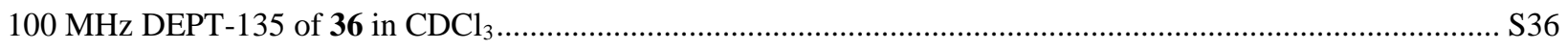

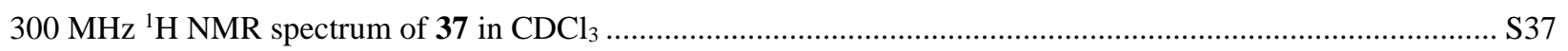

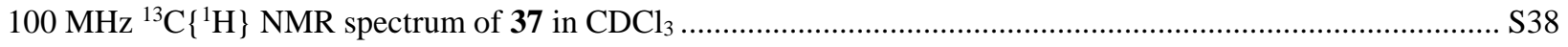

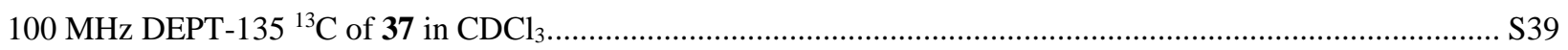

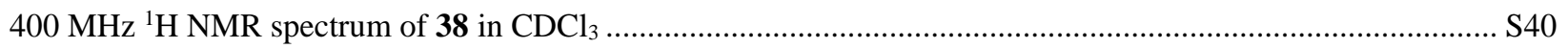

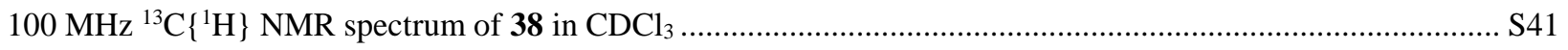

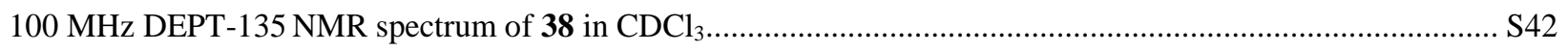

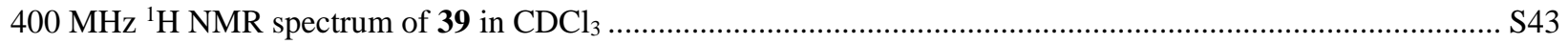

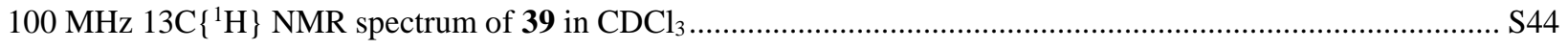

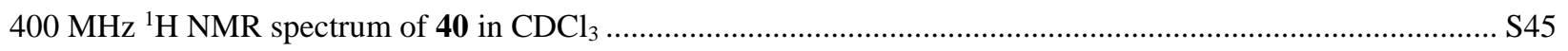

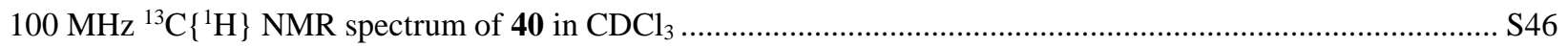

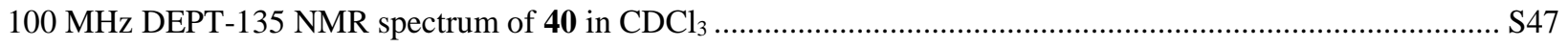

Dose-response data for compound $\mathbf{4 0}$ in the 60 cell line screen ..................................................................... S48

Bioassay data for compound 40 in the 60 cell line screen ................................................................................... S49

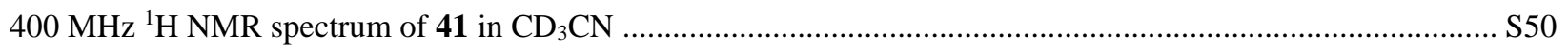

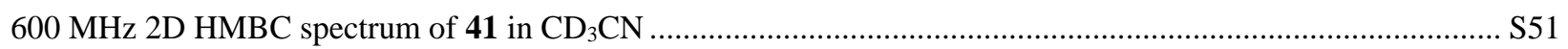

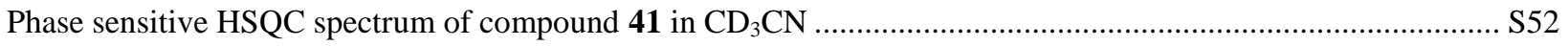

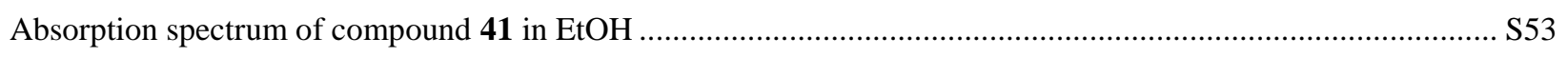

Emission spectrum of compound $\mathbf{4 1}$ in EtOH upon excitation at $420 \mathrm{~nm}$........................................................ S5

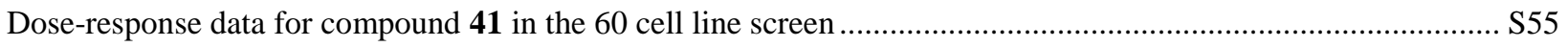

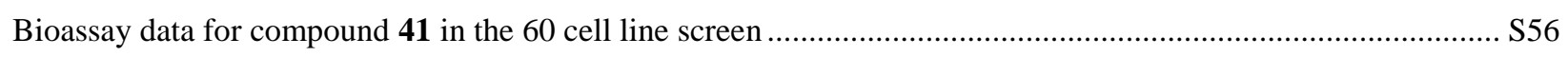

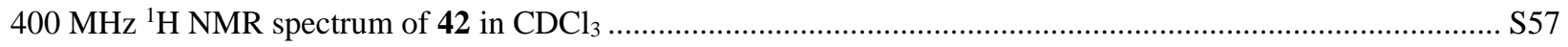

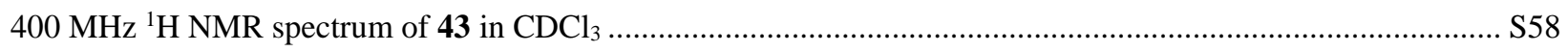

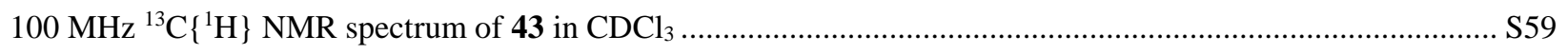

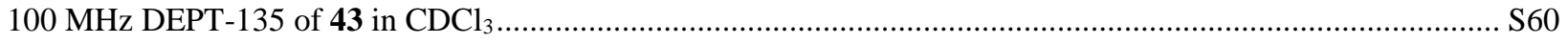

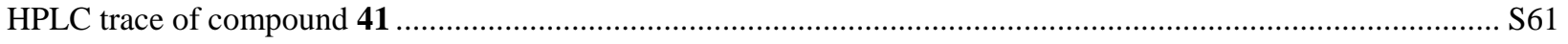


<smiles>O=C(O)c1cc(O)c(Br)c(O)c1</smiles>

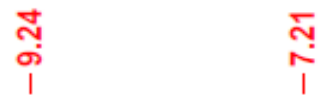

23

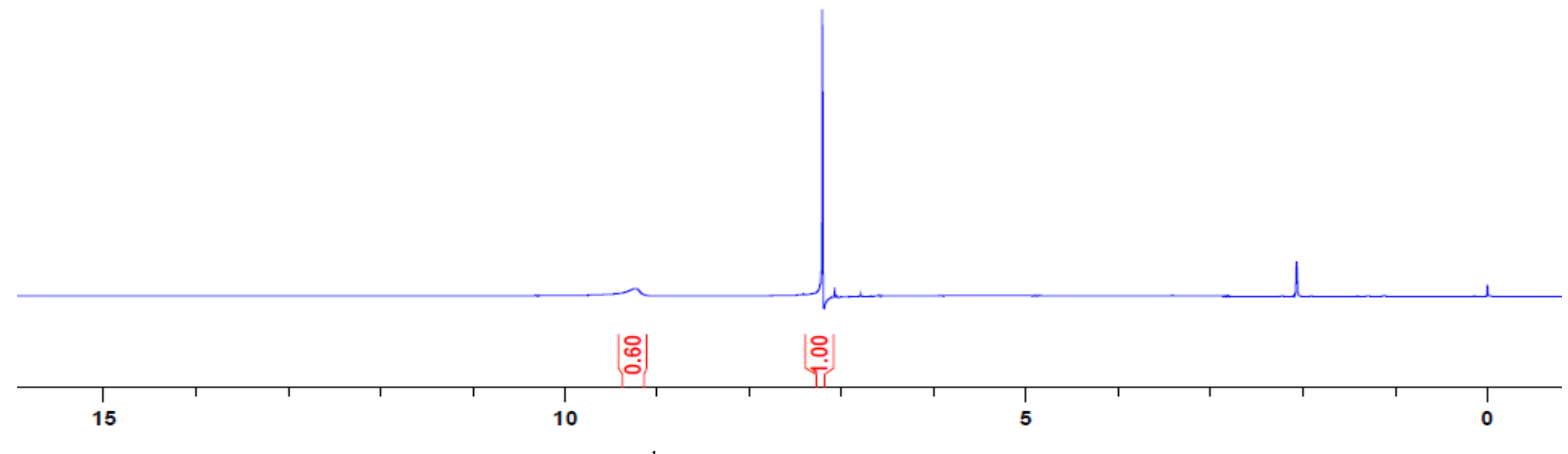

$400 \mathrm{MHz}{ }^{1} \mathrm{H}$ NMR spectrum of 23 in $\mathrm{D}_{3} \mathrm{CC}(\mathrm{O}) \mathrm{CD}_{3}$ 


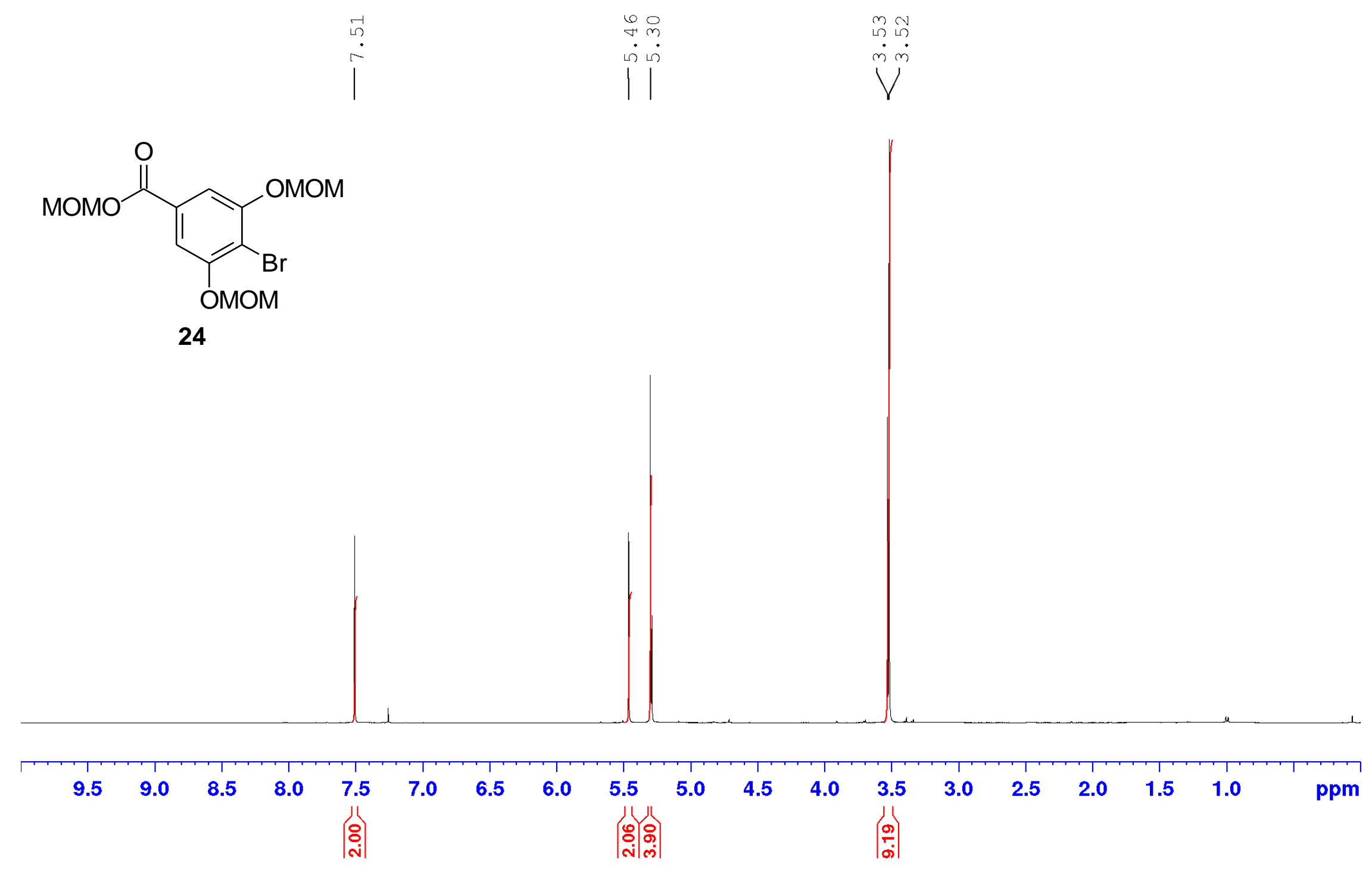

$400 \mathrm{MHz}{ }^{1} \mathrm{H}$ NMR spectrum of 24 in $\mathrm{CDCl}_{3}$ 

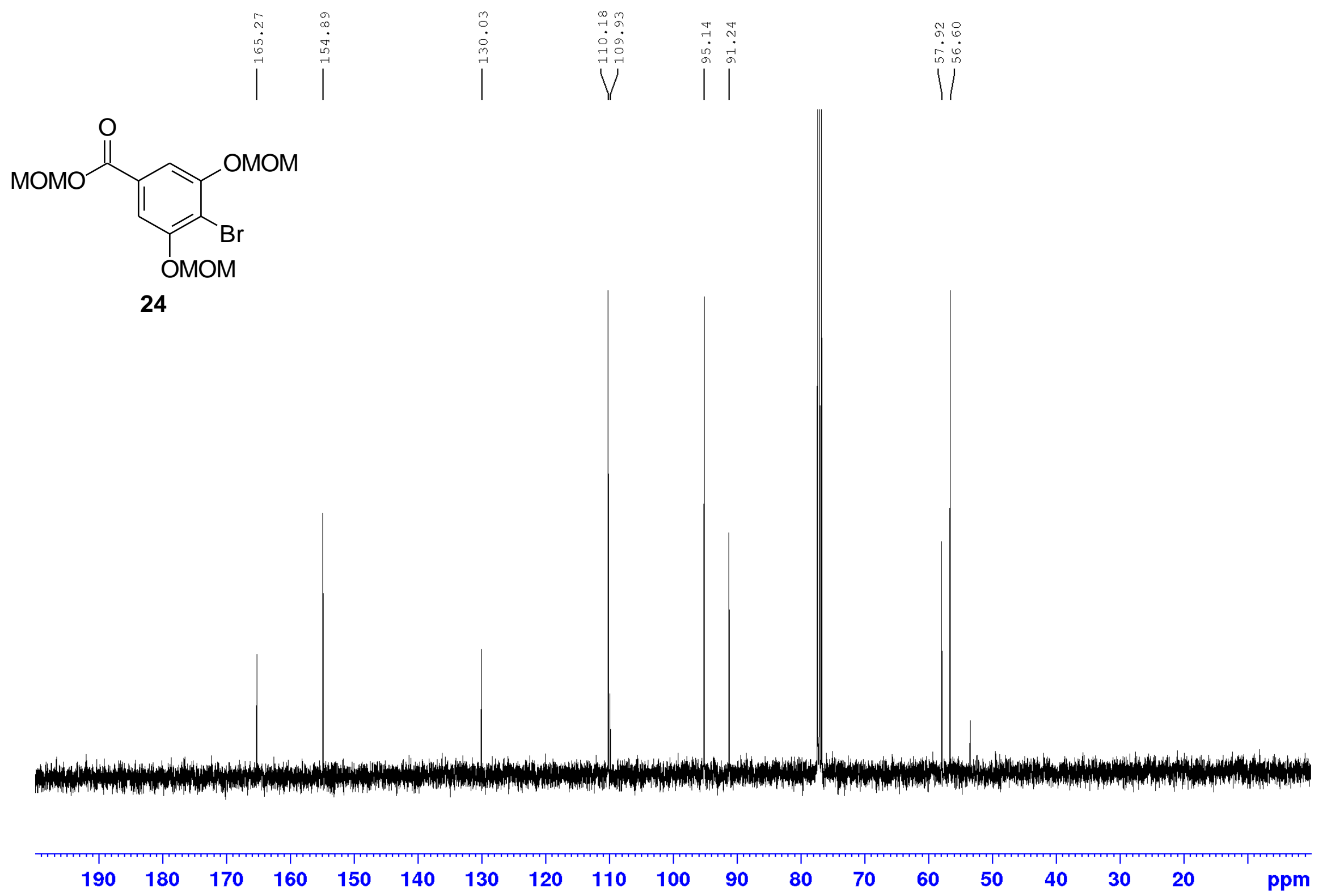

$100 \mathrm{MHz}{ }^{13} \mathrm{C}\left\{{ }^{1} \mathrm{H}\right\}$ NMR spectrum of 24 in $\mathrm{CDCl}_{3}$ 


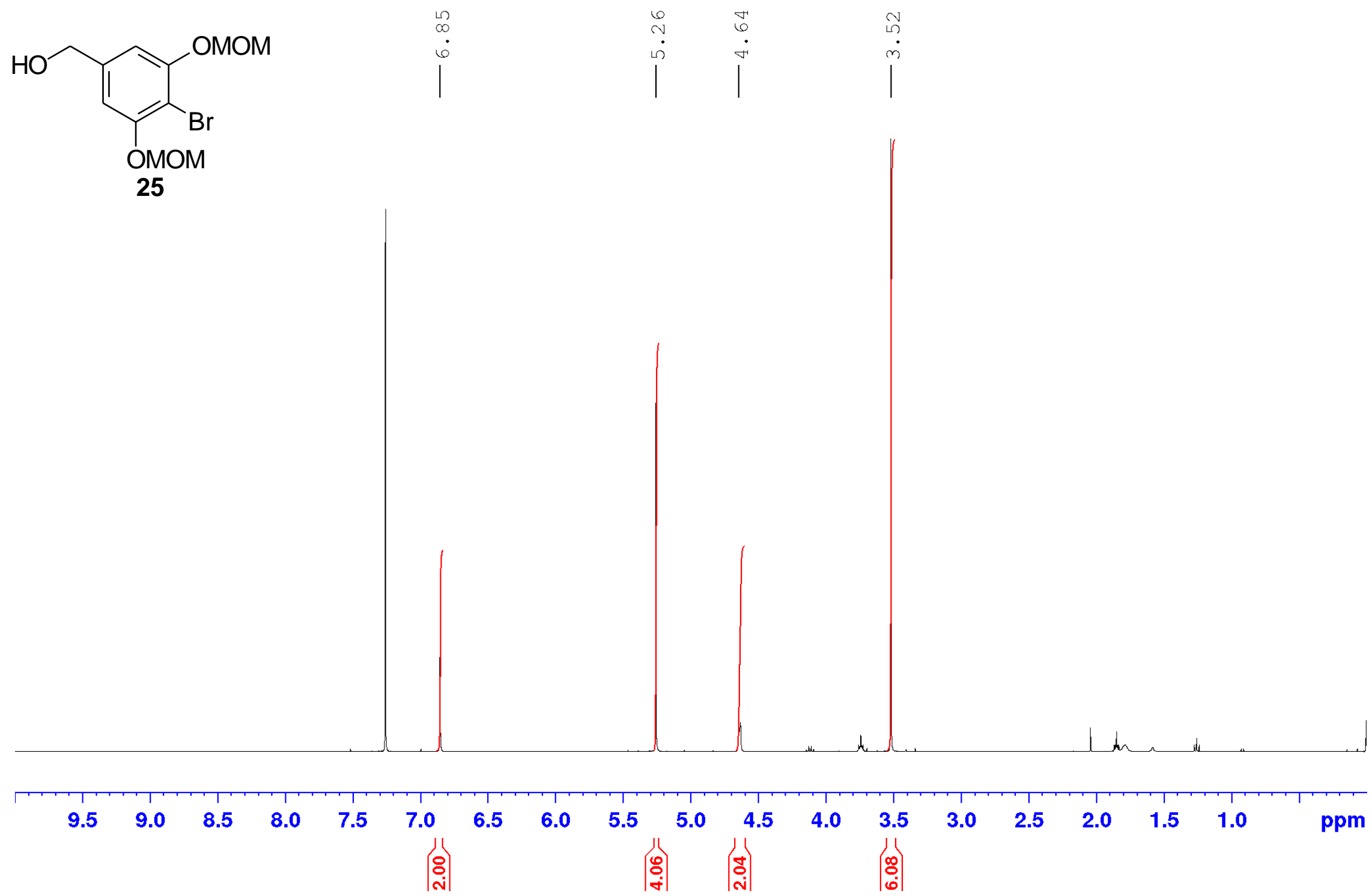

$400 \mathrm{MHz}{ }^{1} \mathrm{H}$ NMR spectrum of 25 in $\mathrm{CDCl}_{3}$ 

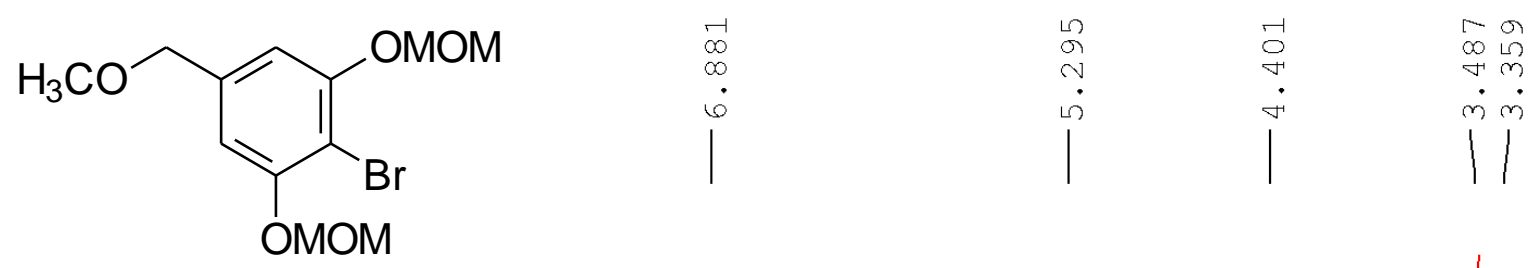

21

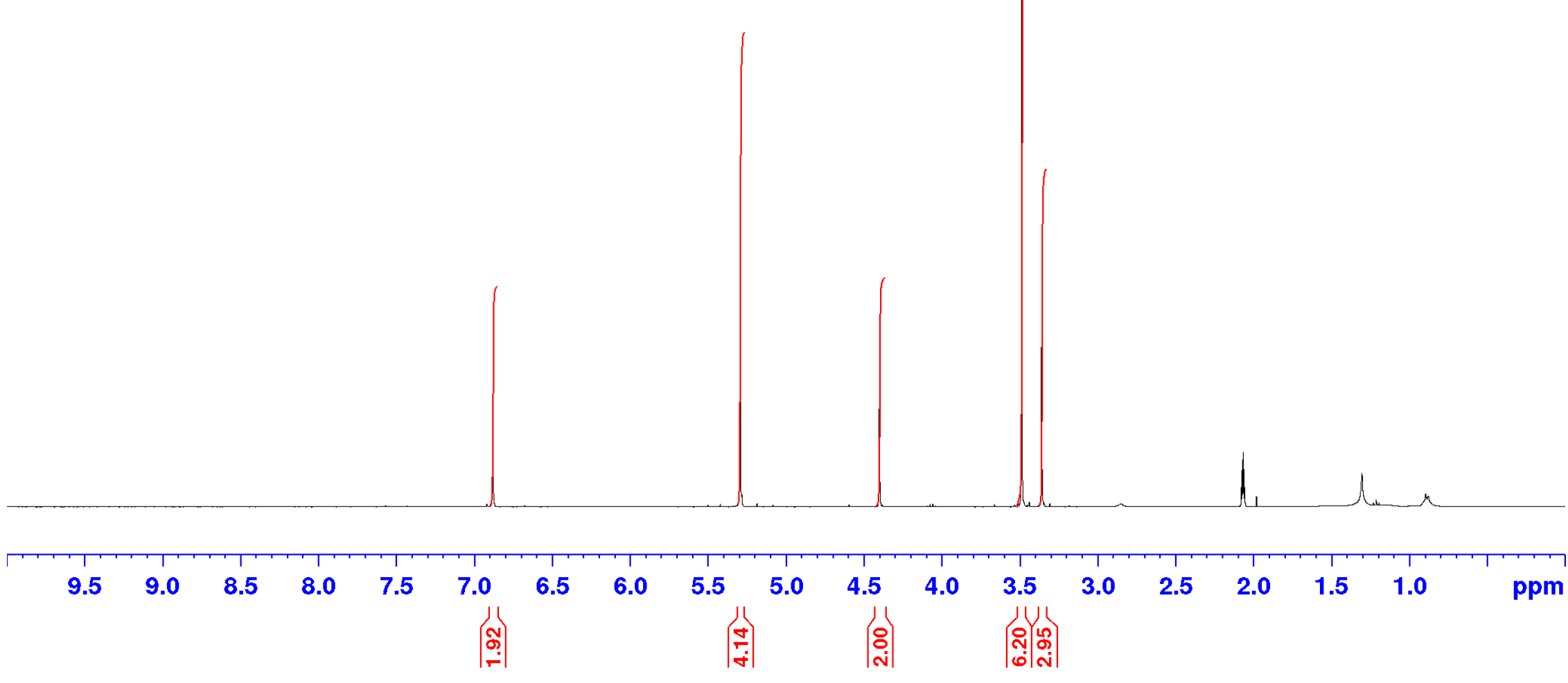

$400 \mathrm{MHz}{ }^{1} \mathrm{H}$ NMR spectrum of 21 in $\left(\mathrm{CD}_{3}\right)_{2} \mathrm{CO}$ 


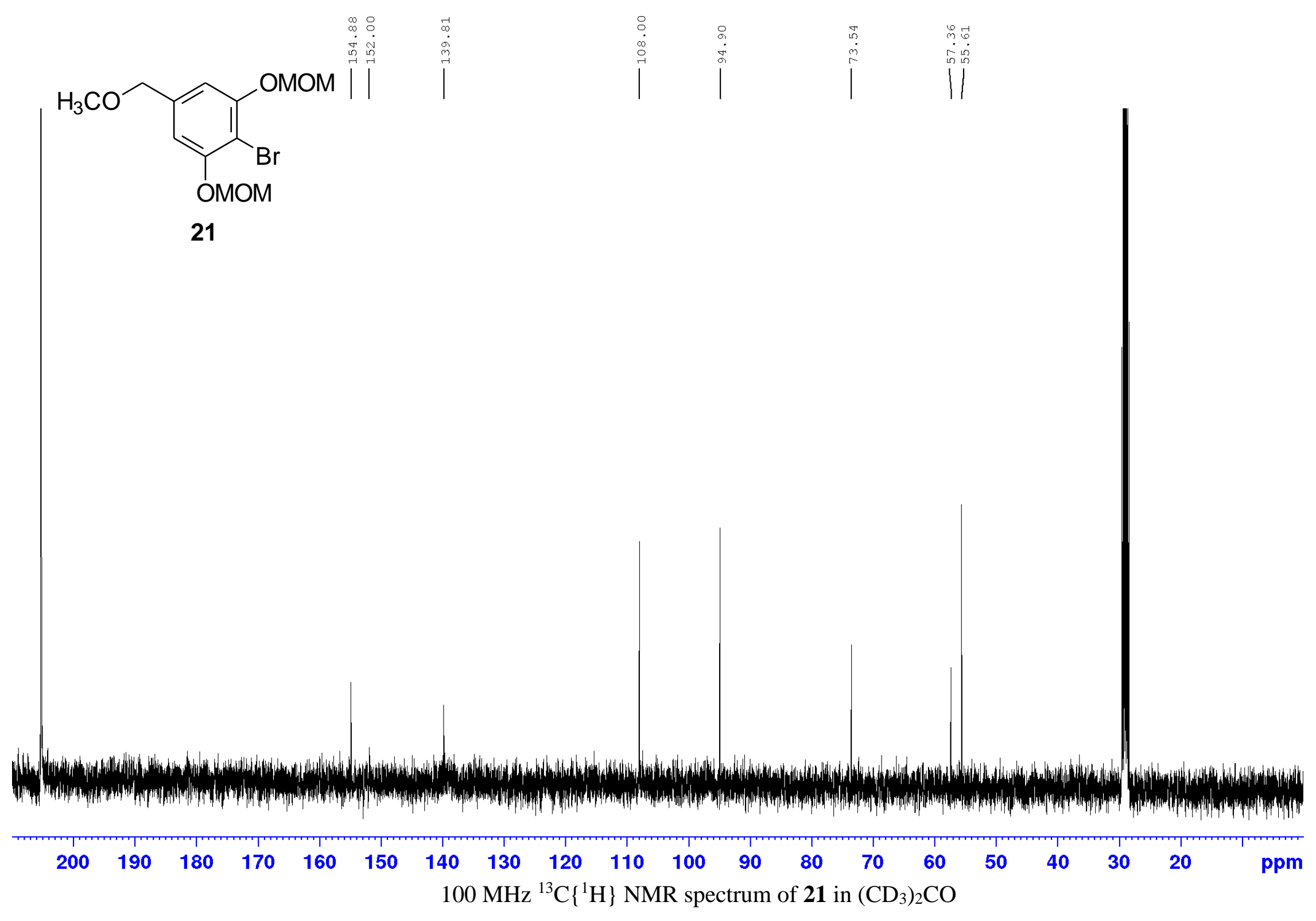


<smiles>COCc1cc(OC)c(Br)c(OC)c1</smiles>

21

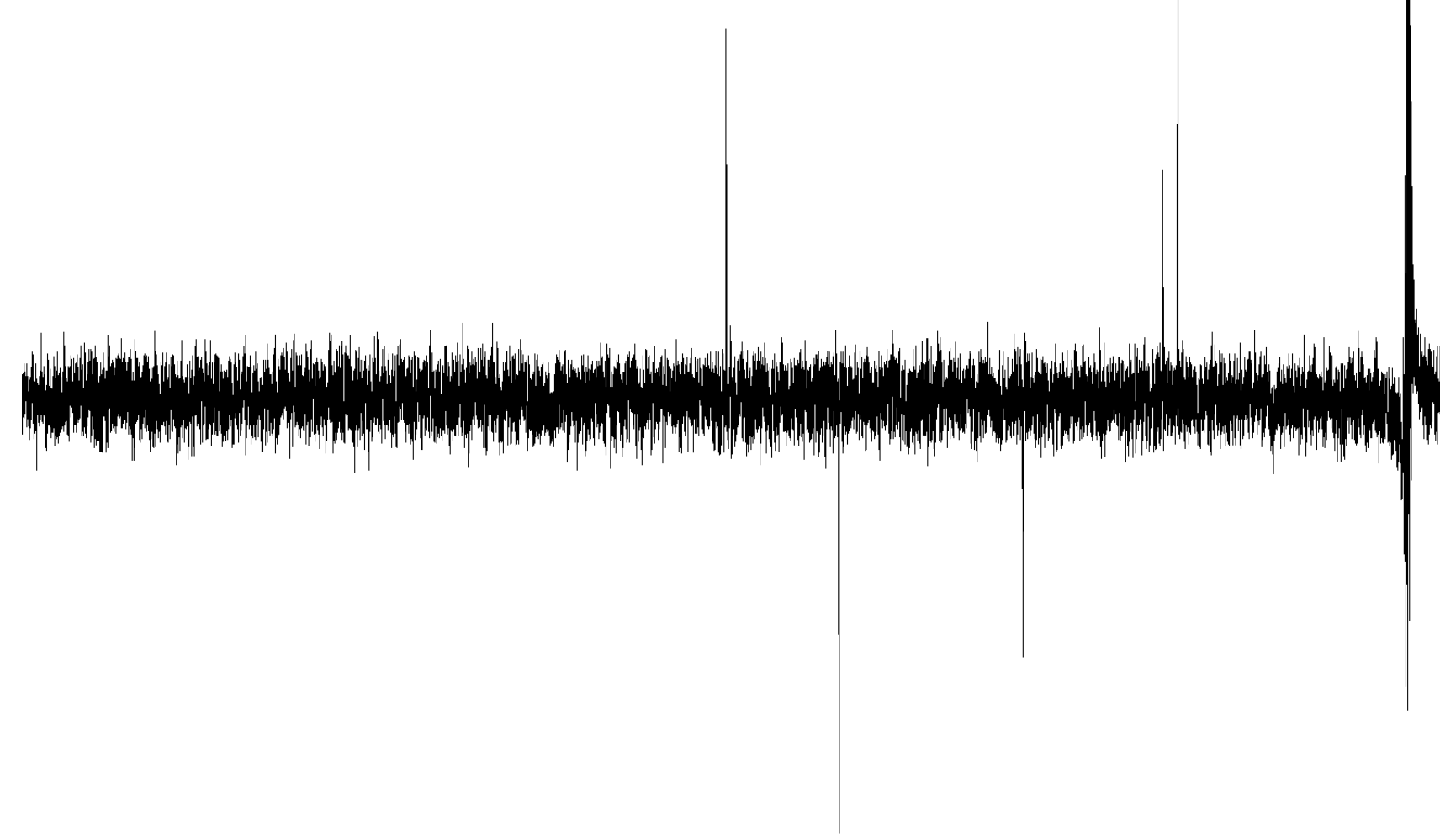

$100 \mathrm{MHz}$ DEPT-135 NMR spectrum of 21 in $\left(\mathrm{CD}_{3}\right)_{2} \mathrm{CO}$ 


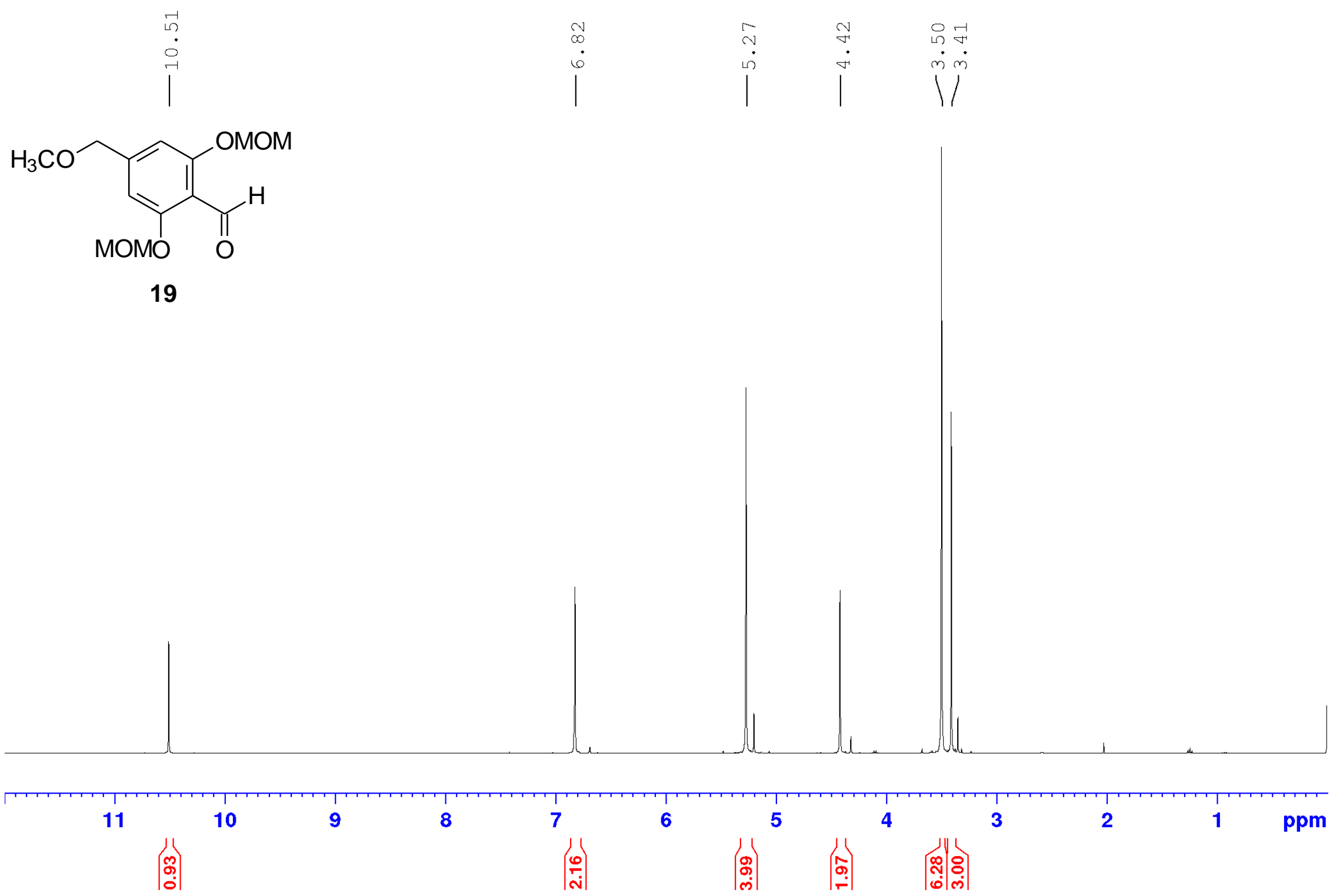

$400 \mathrm{MHz}{ }^{1} \mathrm{H}$ NMR spectrum of 19 in $\mathrm{CDCl}_{3}$ 


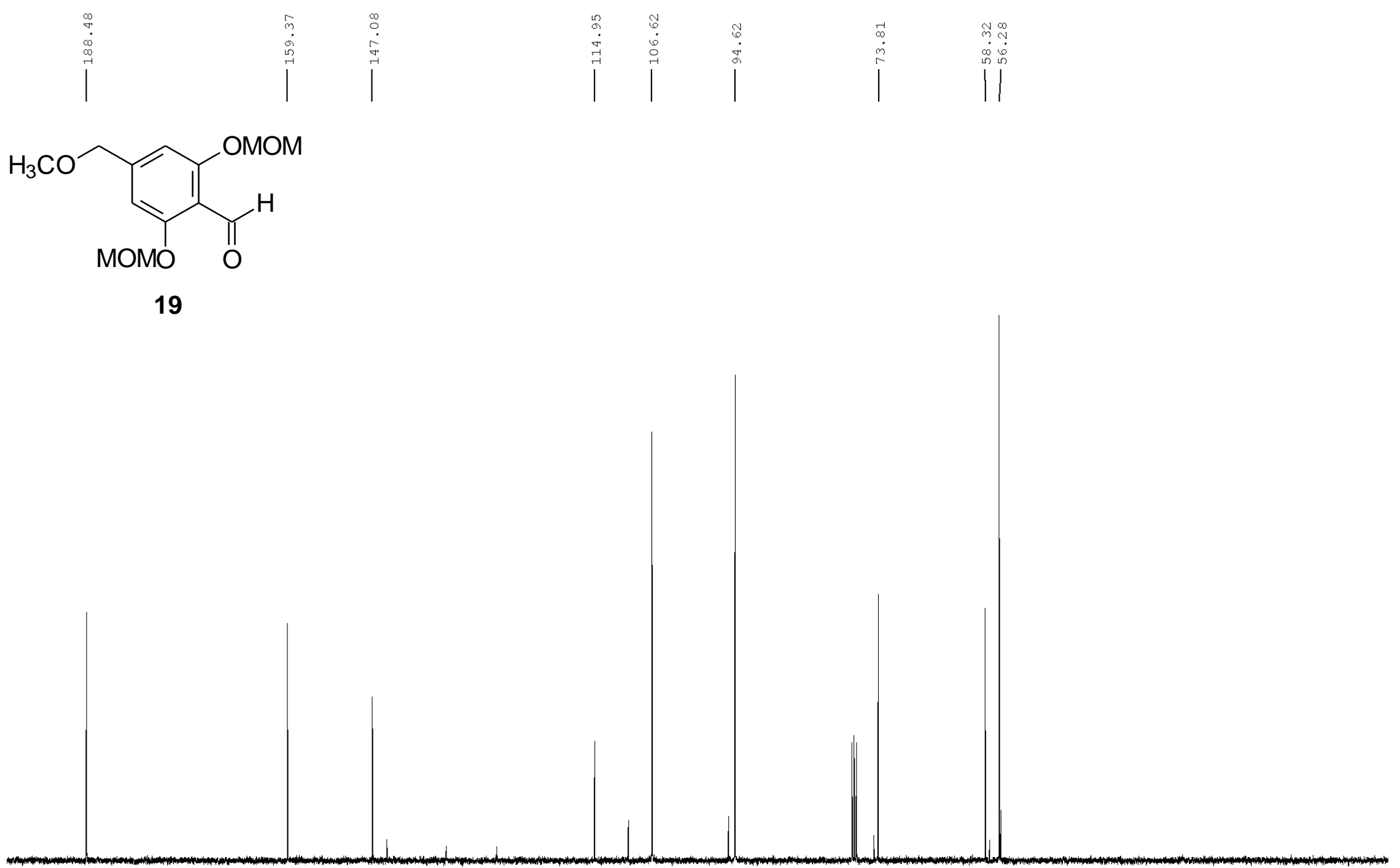

$\begin{array}{lllllllllllllllllll}190 & 180 & 170 & 160 & 150 & 140 & 130 & 120 & 110 & 100 & 90 & 80 & 70 & 60 & 50 & 40 & 30 & 20 & \mathrm{ppm}\end{array}$ $100 \mathrm{MHz}{ }^{13} \mathrm{C}\left\{{ }^{1} \mathrm{H}\right\}$ NMR spectrum of 19 in $\mathrm{CDCl}_{3}$ 


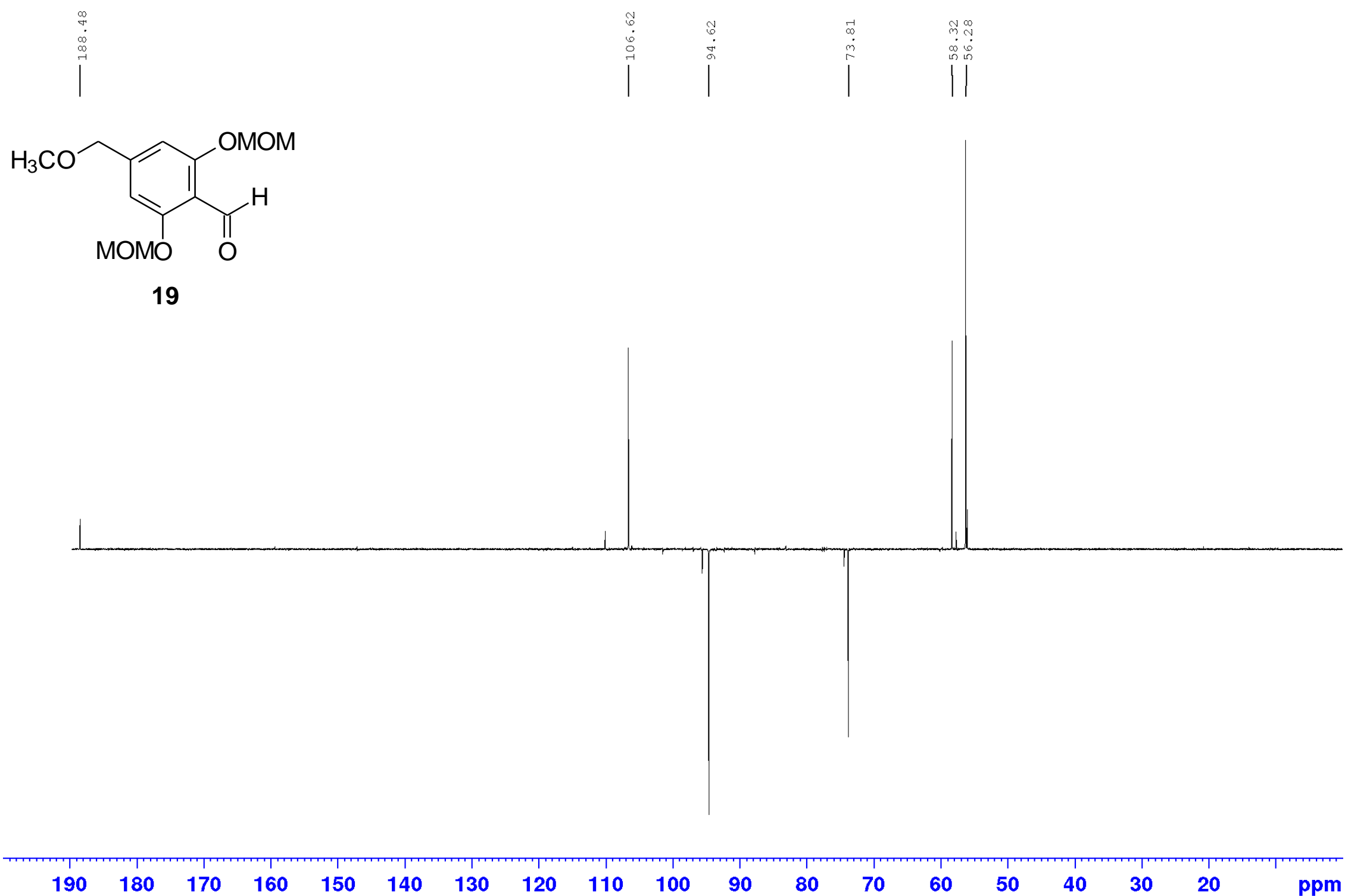

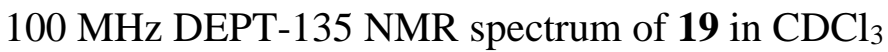




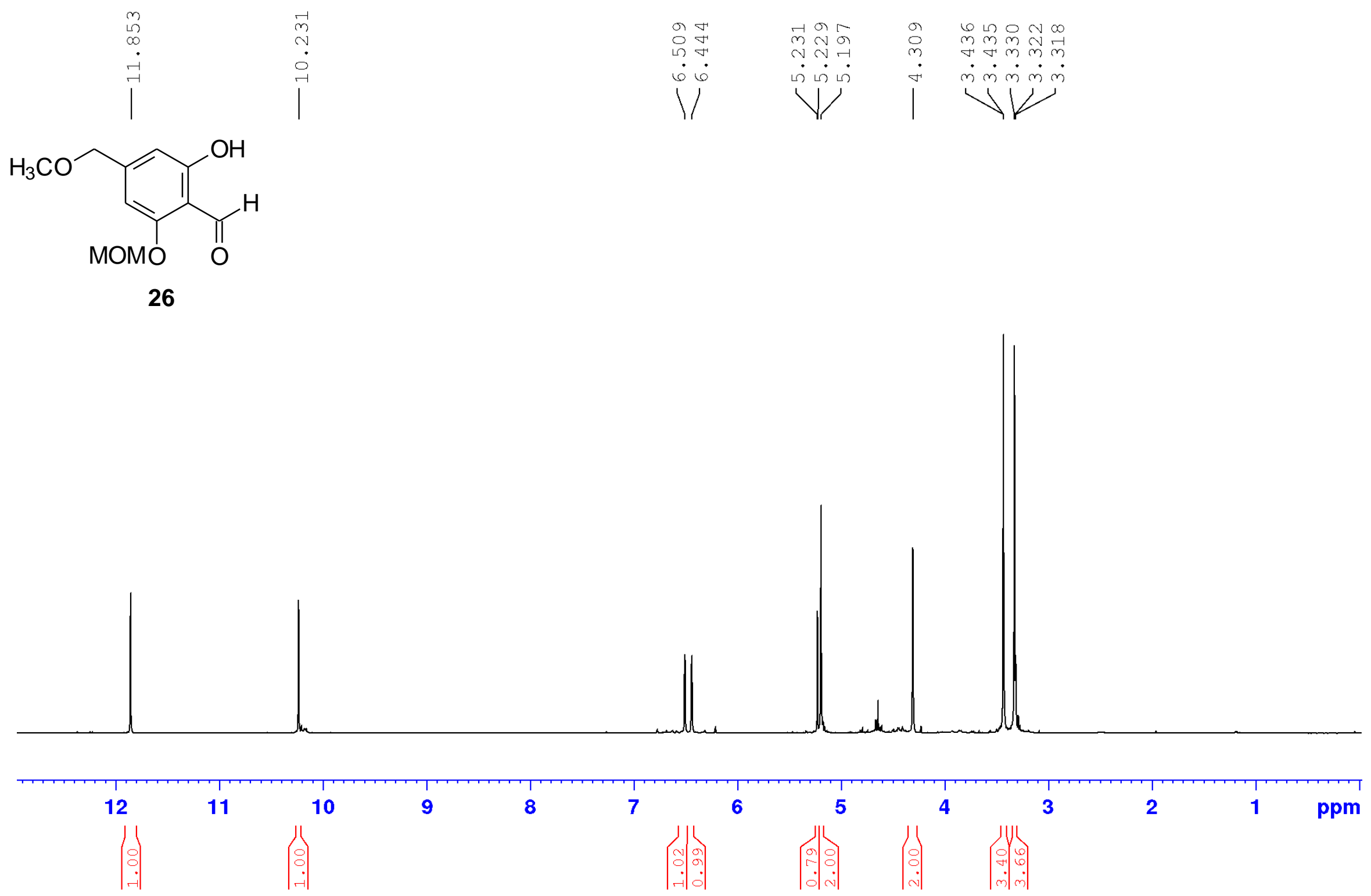

$300 \mathrm{MHz}{ }^{1} \mathrm{H}$ NMR spectrum of 26 in $\mathrm{CDCl}_{3}$ 


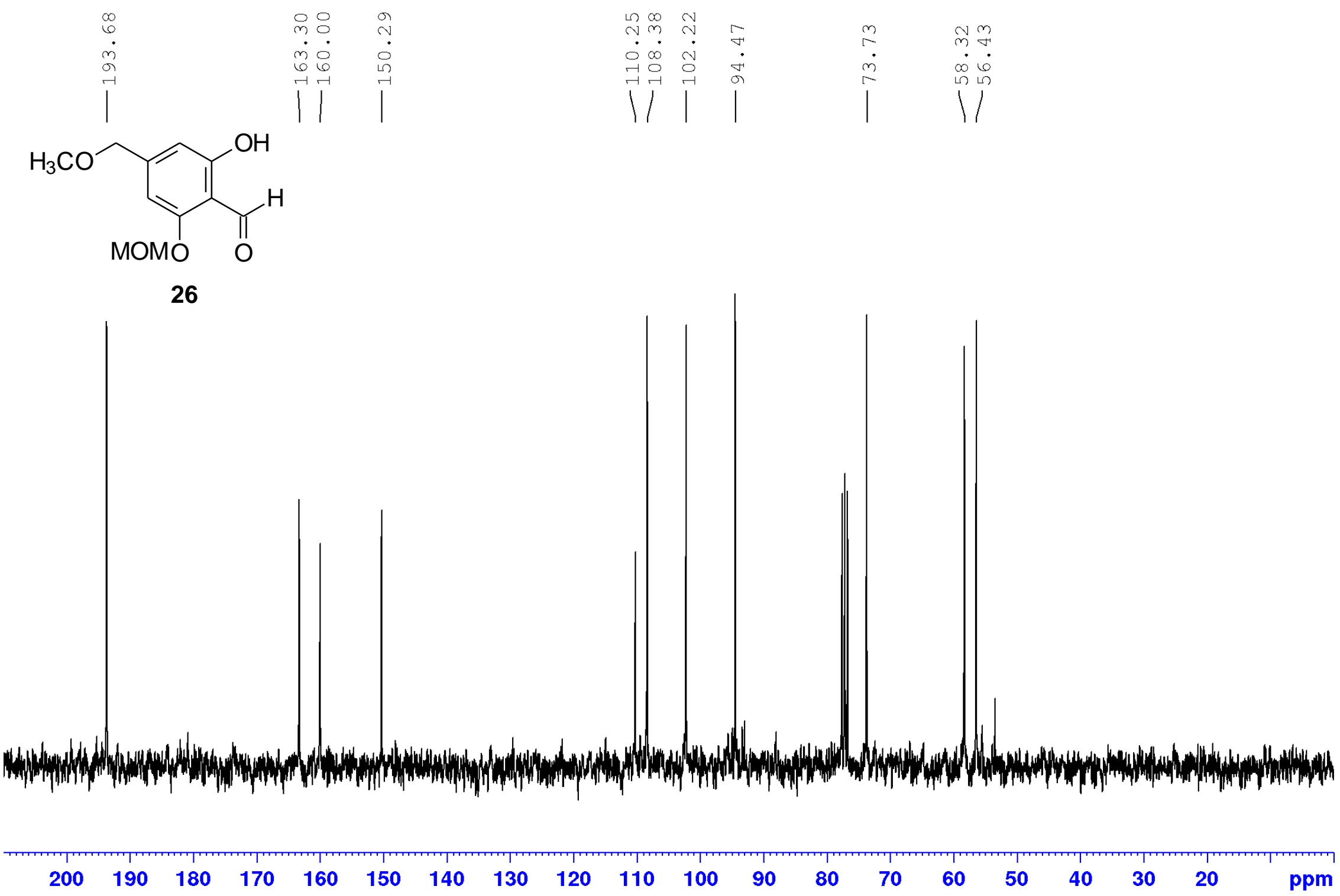

$75 \mathrm{MHz}{ }^{13} \mathrm{C}\left\{{ }^{1} \mathrm{H}\right\}$ NMR spectrum of 26 in $\mathrm{CDCl}_{3}$ 


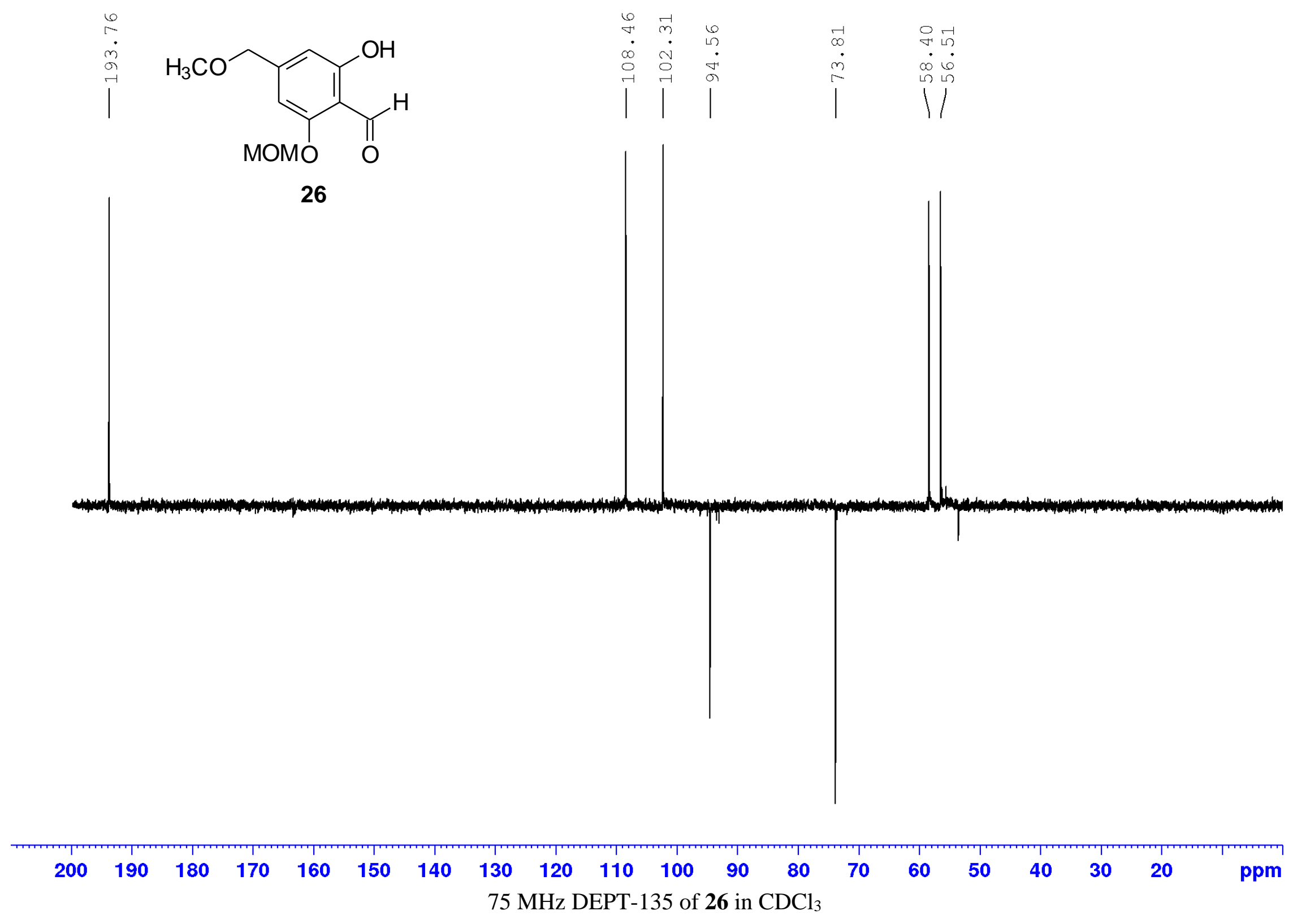




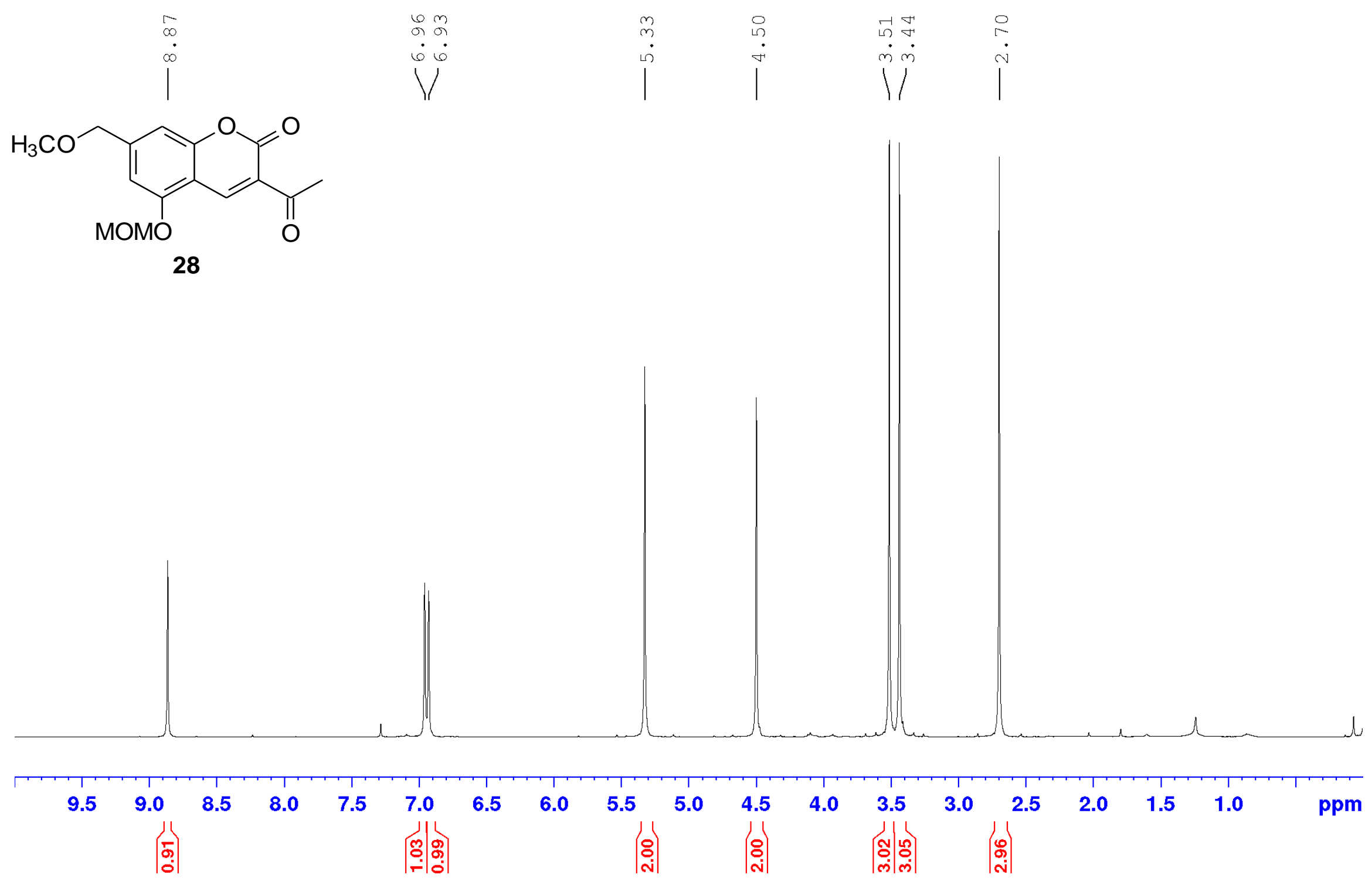

$300 \mathrm{MHz}{ }^{1} \mathrm{H}$ NMR spectrum of 28 in $\mathrm{CDCl}_{3}$ 


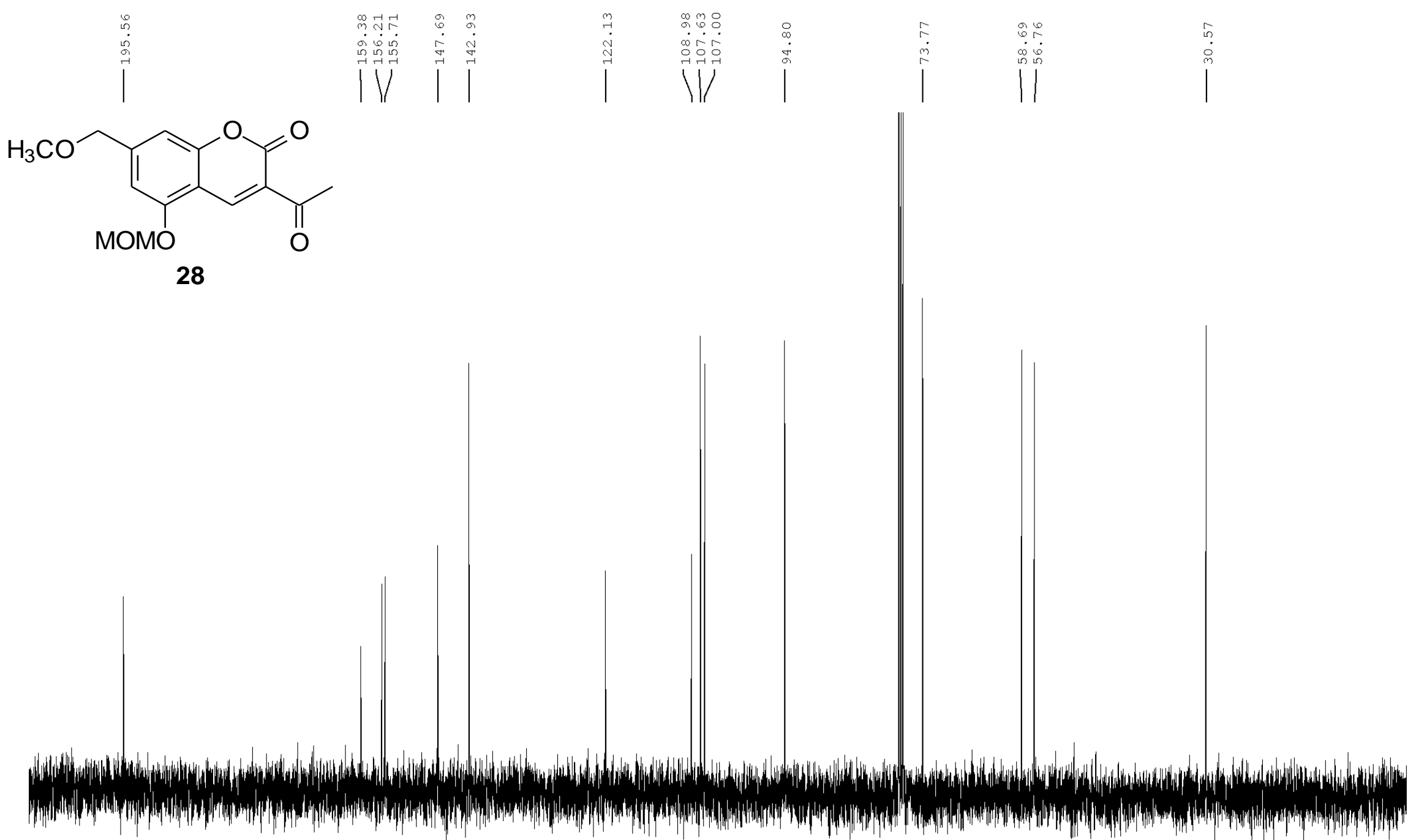

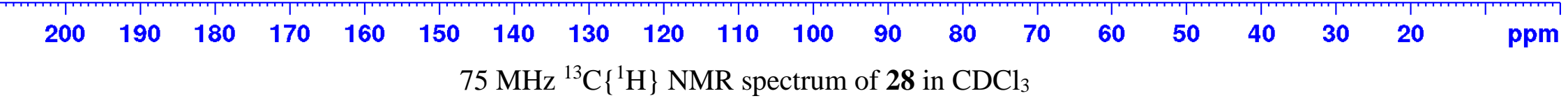




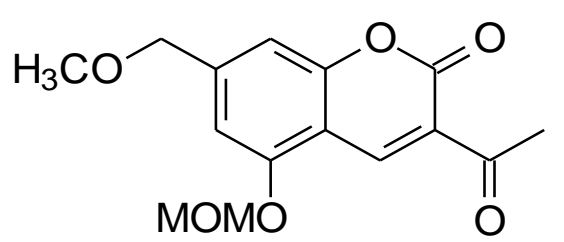

$\stackrel{n}{i}$

28

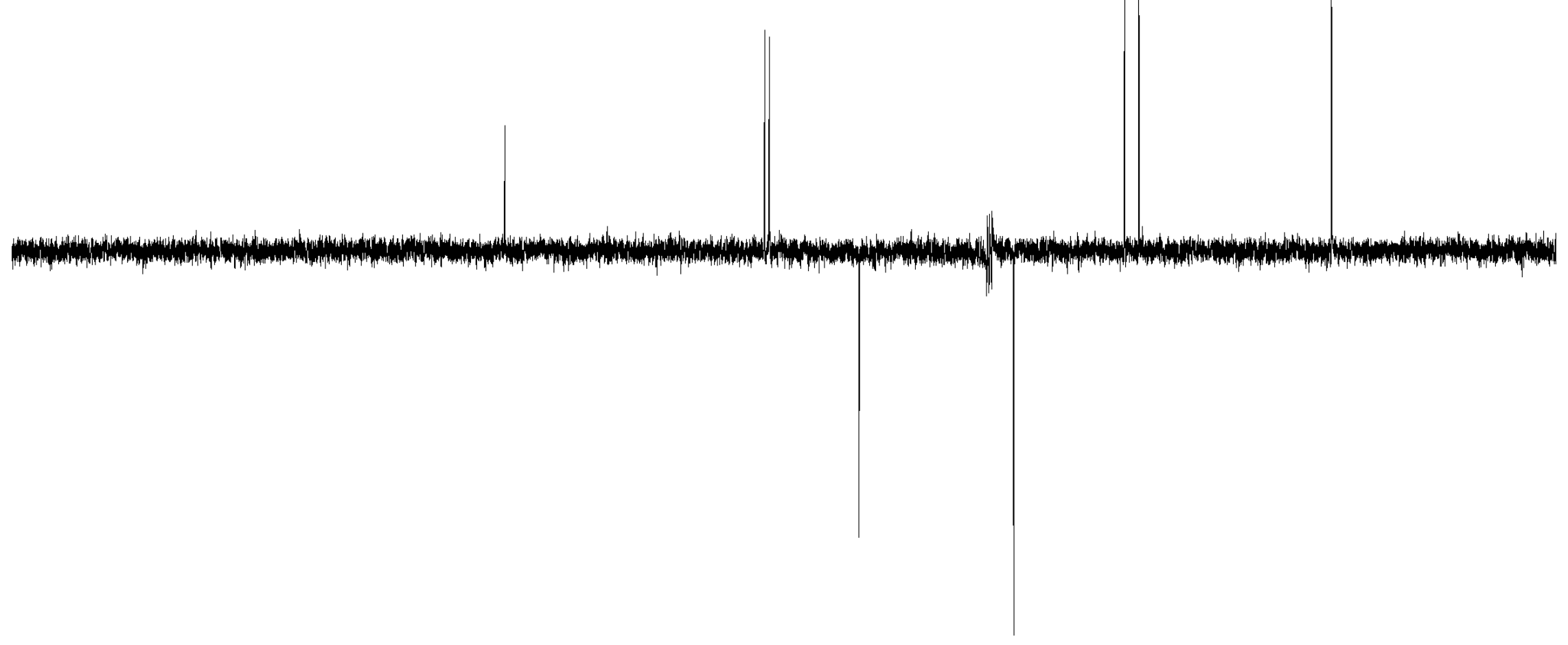

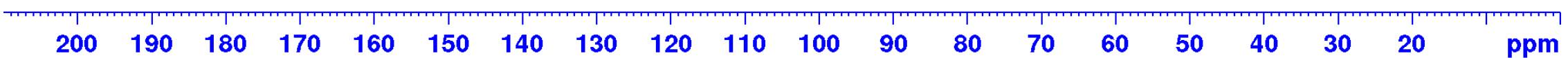

$75 \mathrm{MHz}$ DEPT-135 of 28 in $\mathrm{CDCl}_{3}$ 


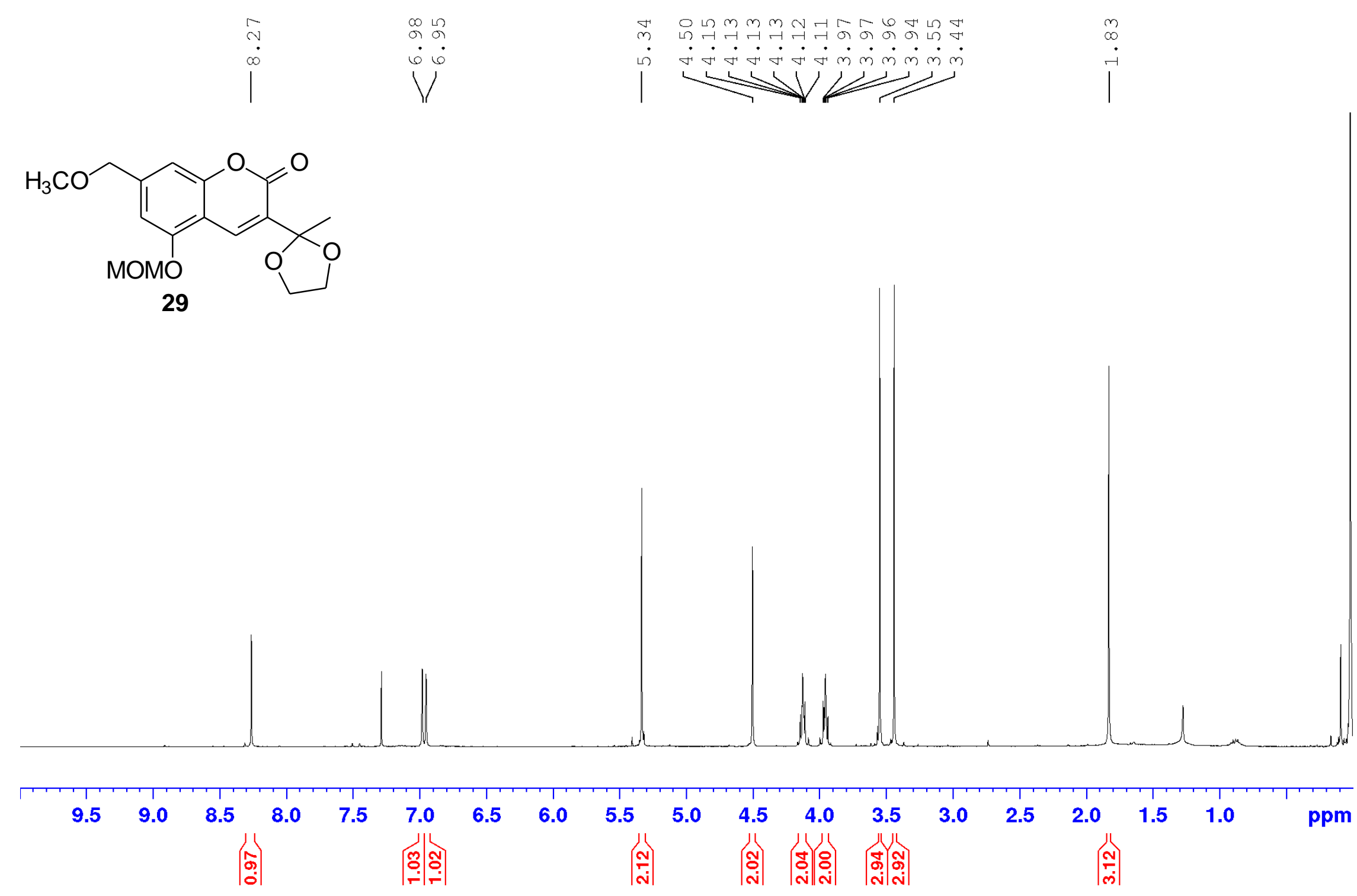

$400 \mathrm{MHz}{ }^{1} \mathrm{H}$ NMR spectrum of 29 in $\mathrm{CDCl}_{3}$ 


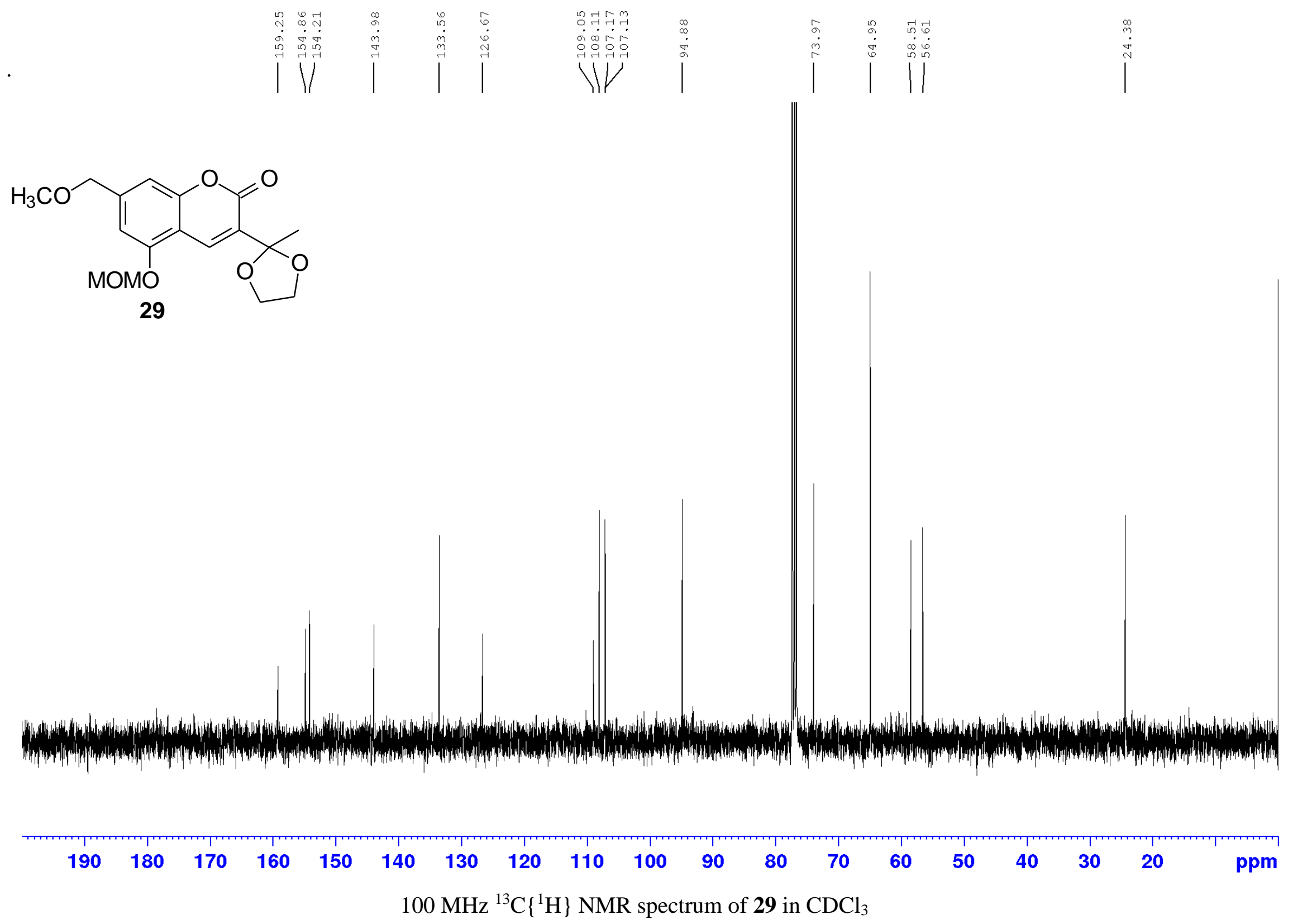




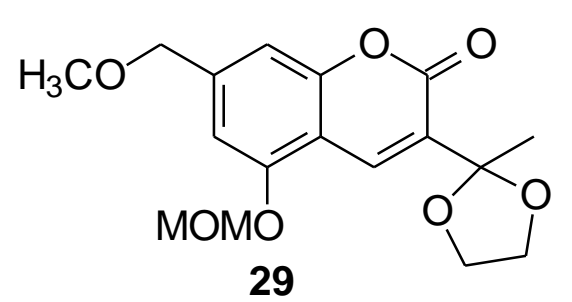

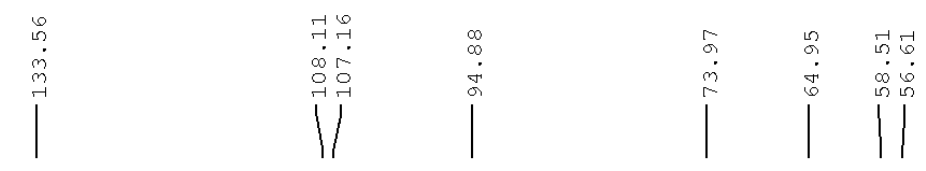

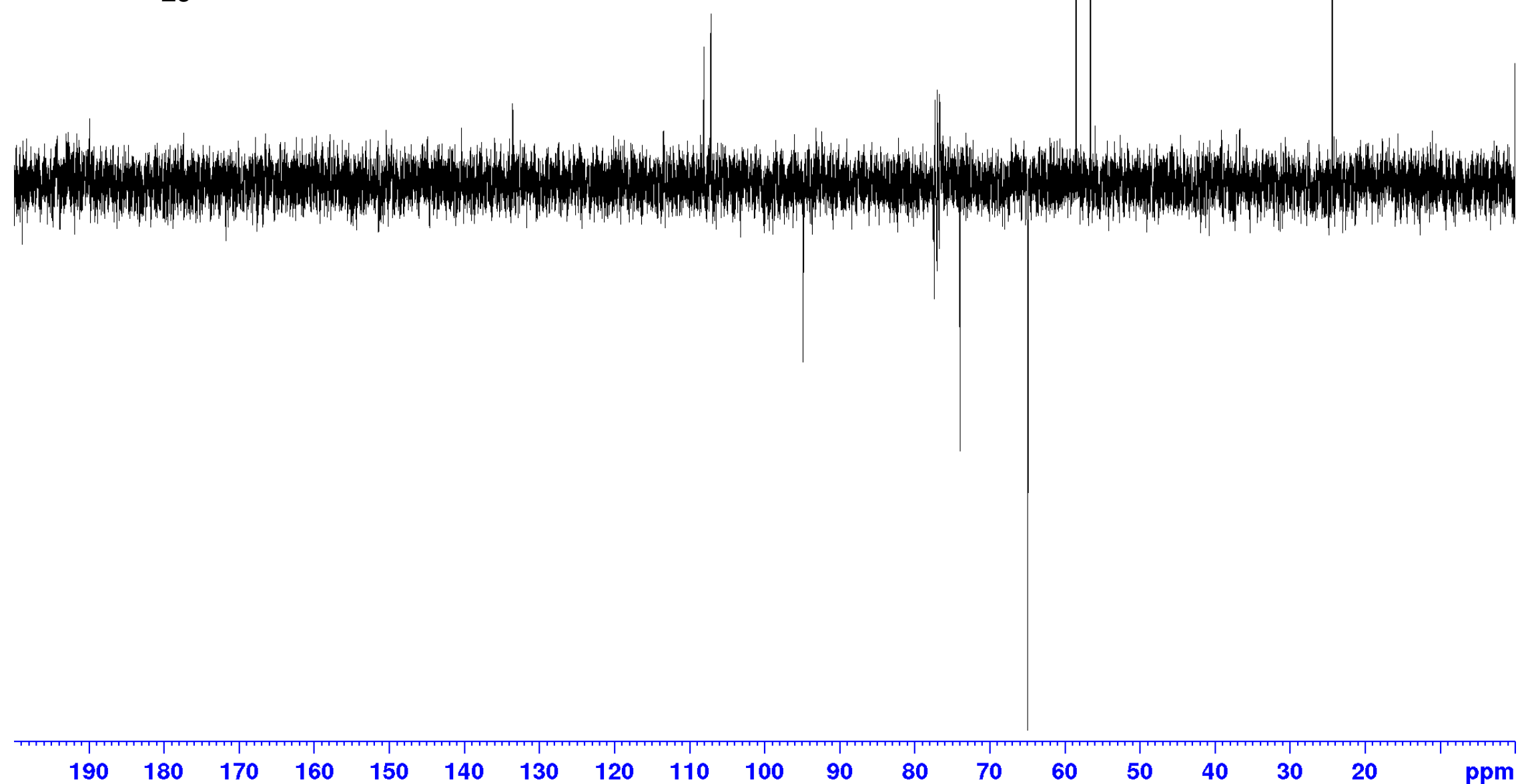

$100 \mathrm{MHz}$ DEPT-135 of 29 in $\mathrm{CDCl}_{3}$ 

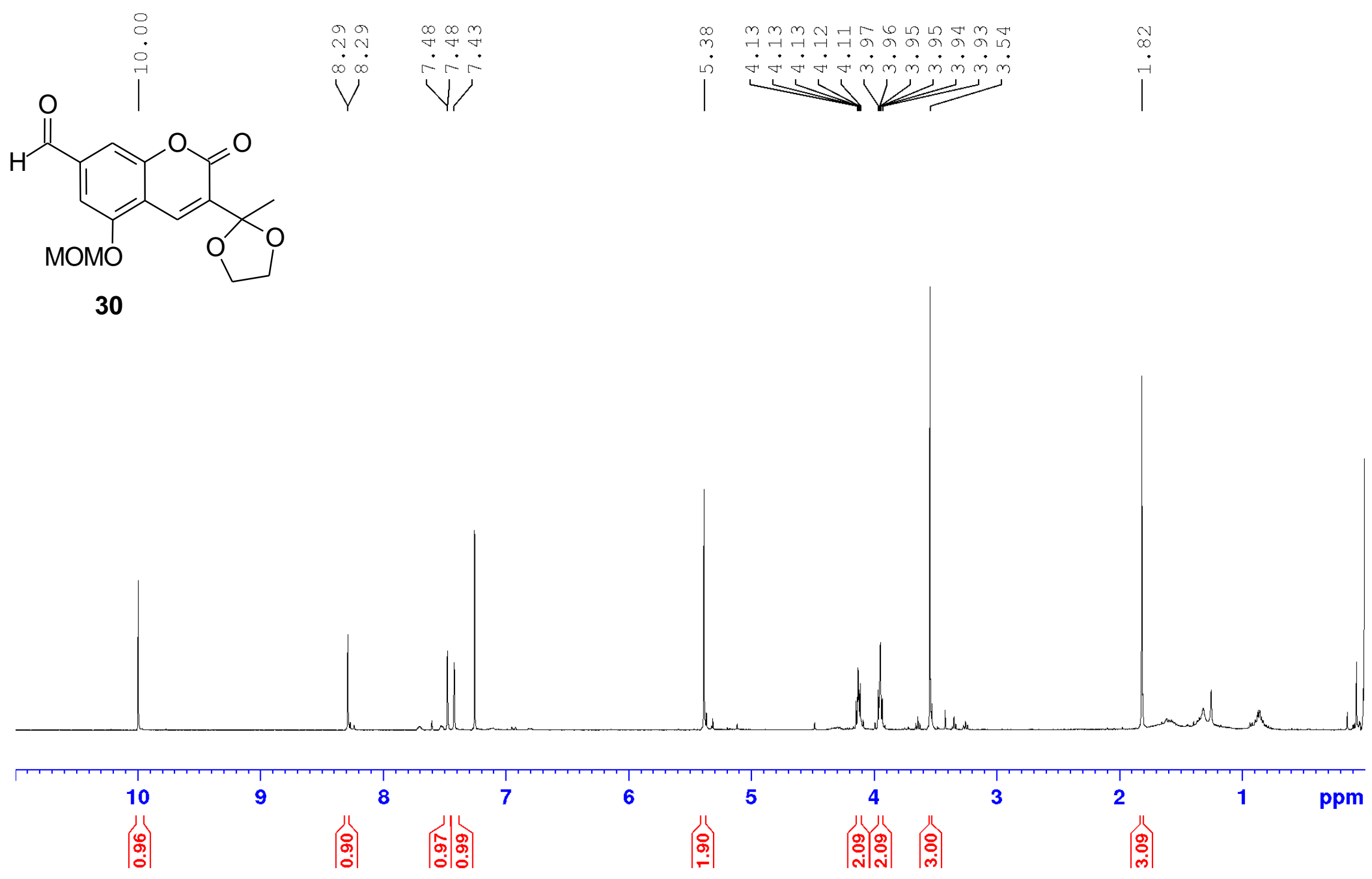

$400 \mathrm{MHz}{ }^{1} \mathrm{H}$ NMR spectrum of $\mathbf{3 0}$ in $\mathrm{CDCl}_{3}$ 


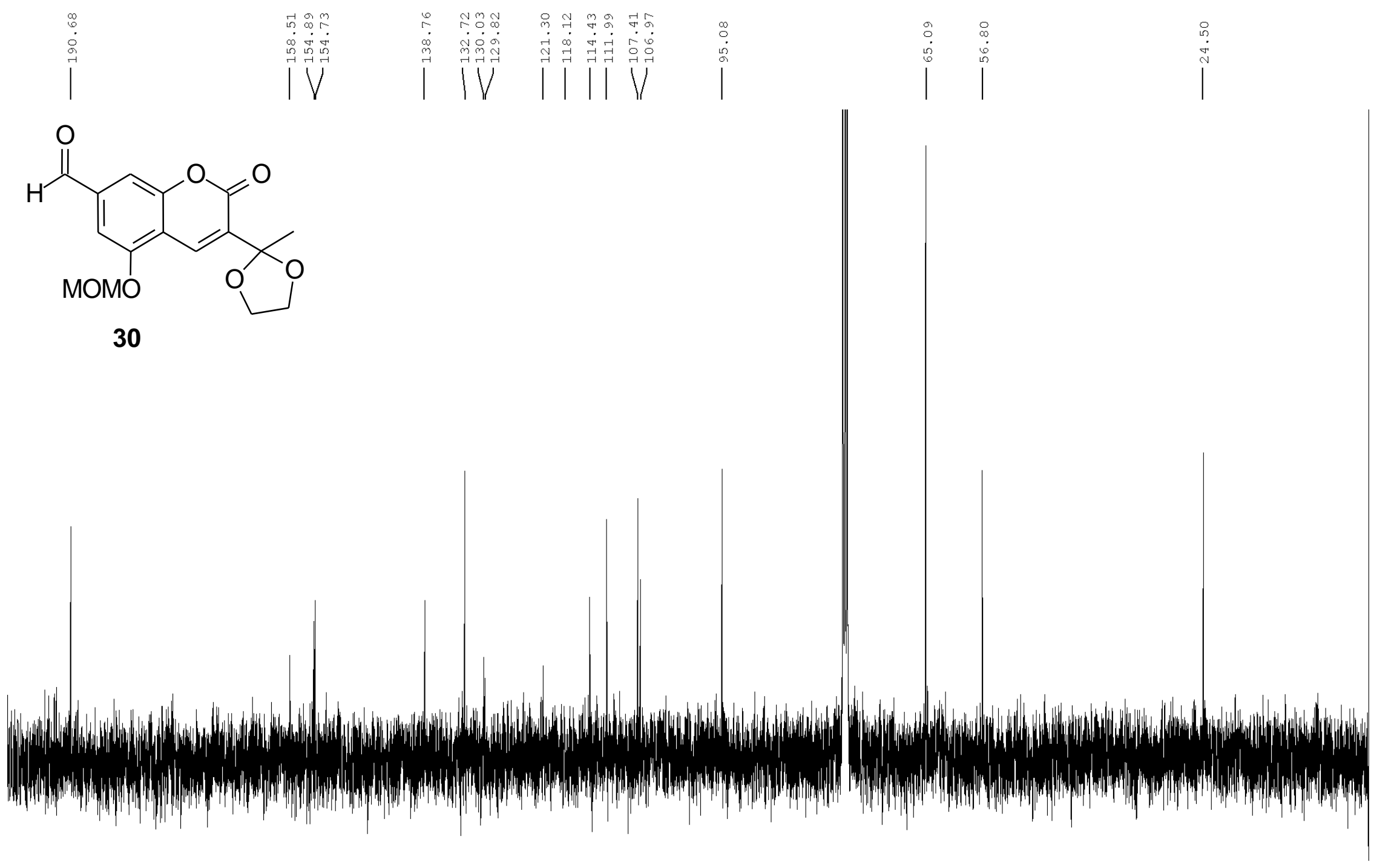

$\begin{array}{lllllllllllllllllllll}190 & 180 & 170 & 160 & 150 & 140 & 130 & 120 & 110 & 100 & 90 & 80 & 70 & 60 & 50 & 40 & 30 & 20 & \mathrm{ppm}\end{array}$

$100 \mathrm{MHz}{ }^{13} \mathrm{C}\left\{{ }^{1} \mathrm{H}\right\}$ NMR spectrum of $\mathbf{3 0}$ in $\mathrm{CDCl}_{3}$ 
<smiles>COc1cc(C=O)cc2oc(=O)c(C3(C)OCCO3)cc12</smiles>

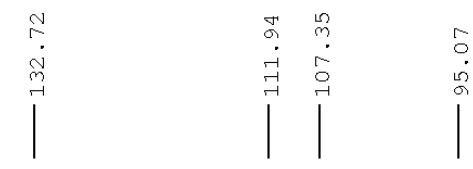

30

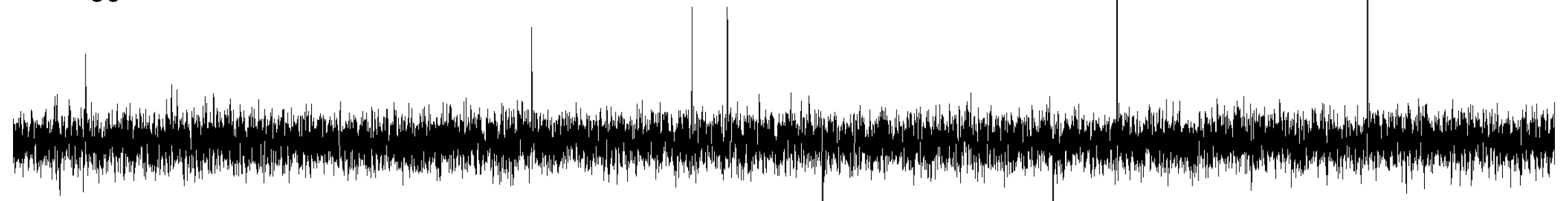

$\begin{array}{llll}190 & 180 & 170 & 160\end{array}$

150

140

130

120

110

100

$90 \quad 80$

70

60

40

30

20

ppm

$100 \mathrm{MHz}$ DEPT-135 of $\mathbf{3 0}$ in $\mathrm{CDCl}_{3}$ 


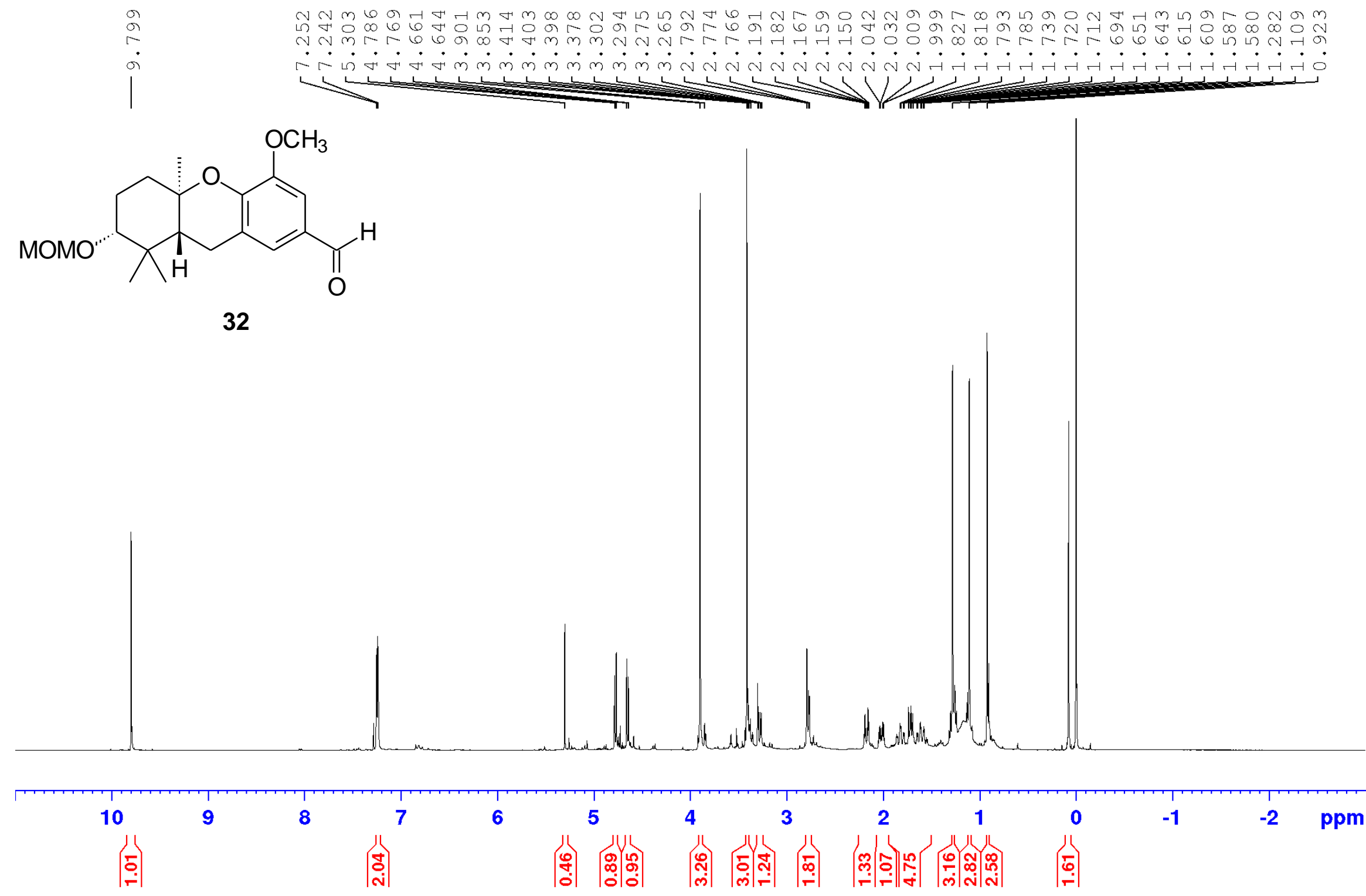

$400 \mathrm{MHz}{ }^{1} \mathrm{H}$ NMR spectrum of 32 in $\mathrm{CDCl}_{3}$ 


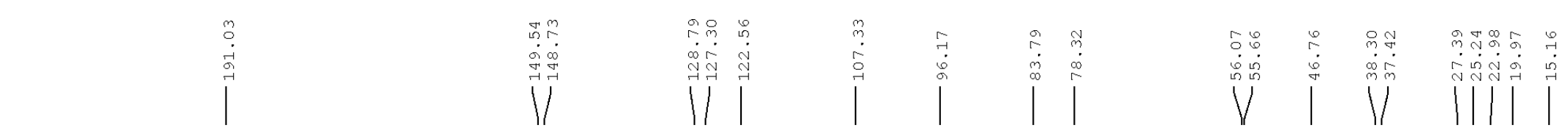<smiles>COc1cc(C=O)cc2c1O[C@H]1CC[C@H](OC)C(C)(C)C1C2</smiles>

32

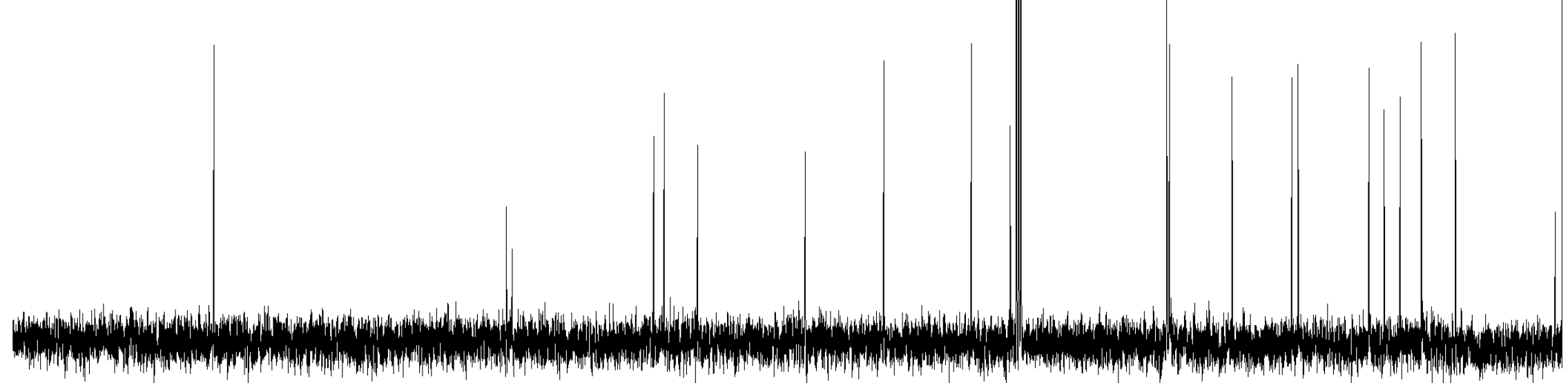

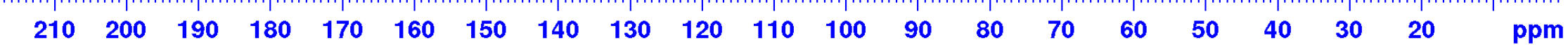

$100 \mathrm{MHz}{ }^{13} \mathrm{C}\left\{{ }^{1} \mathrm{H}\right\}$ NMR spectrum of $\mathbf{3 2}$ in $\mathrm{CDCl}_{3}$ 

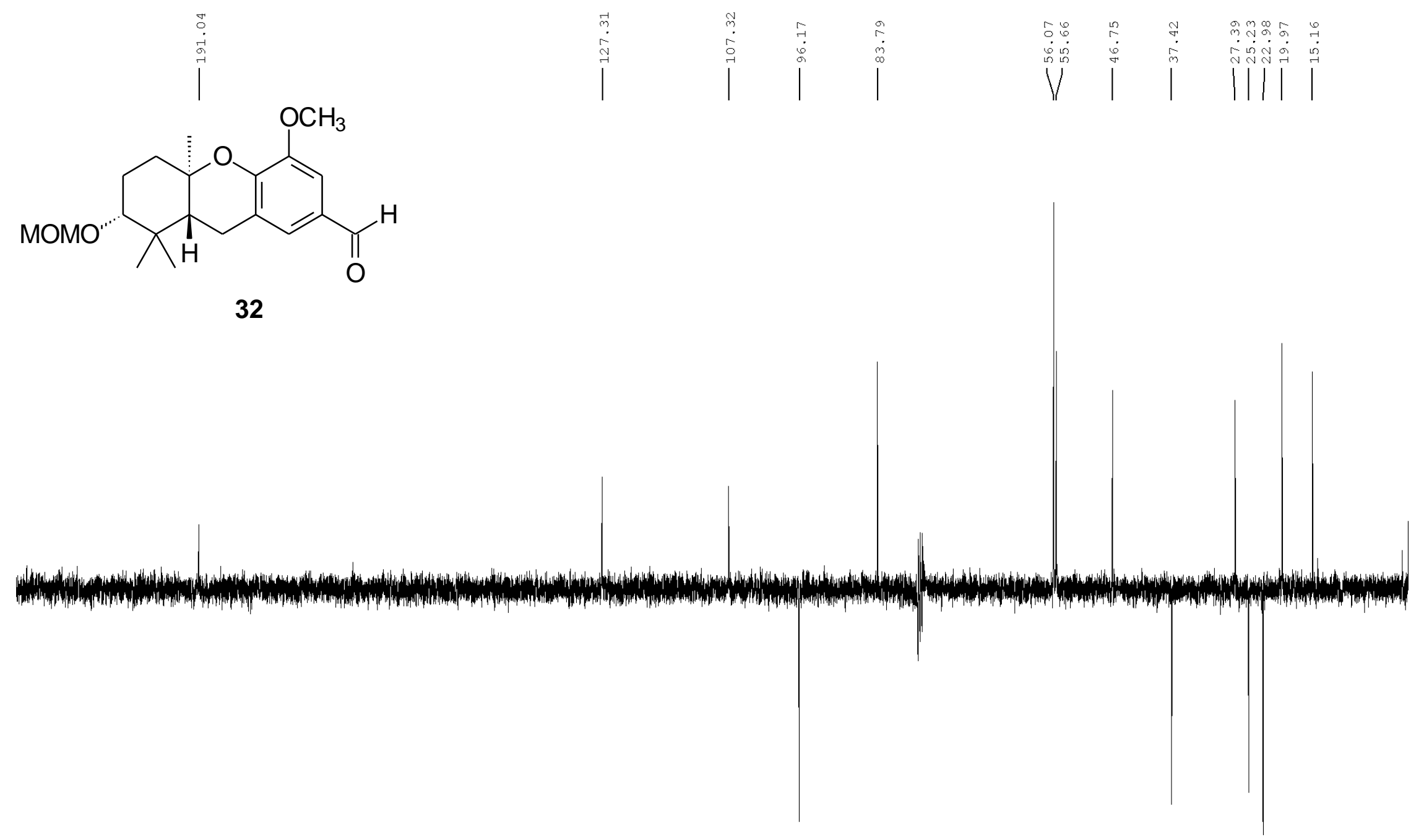

$\begin{array}{lllllllllllllllllllll}210 & 200 & 190 & 180 & 170 & 160 & 150 & 140 & 130 & 120 & 110 & 100 & 90 & 80 & 70 & 60 & 50 & 40 & 30 & 20 & \mathrm{ppm}\end{array}$

$100 \mathrm{MHz}$ DEPT-135 NMR spectrum of 32 in $\mathrm{CDCl}_{3}$ 
<smiles>COc1cc(CO)cc2c1O[C@H]1CC[C@H](OC)C(C)(C)[C@H]1C2</smiles>

17
파

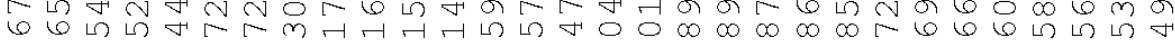

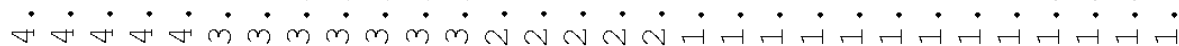

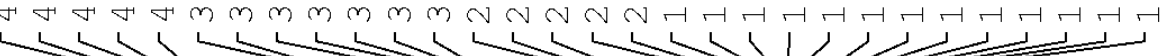

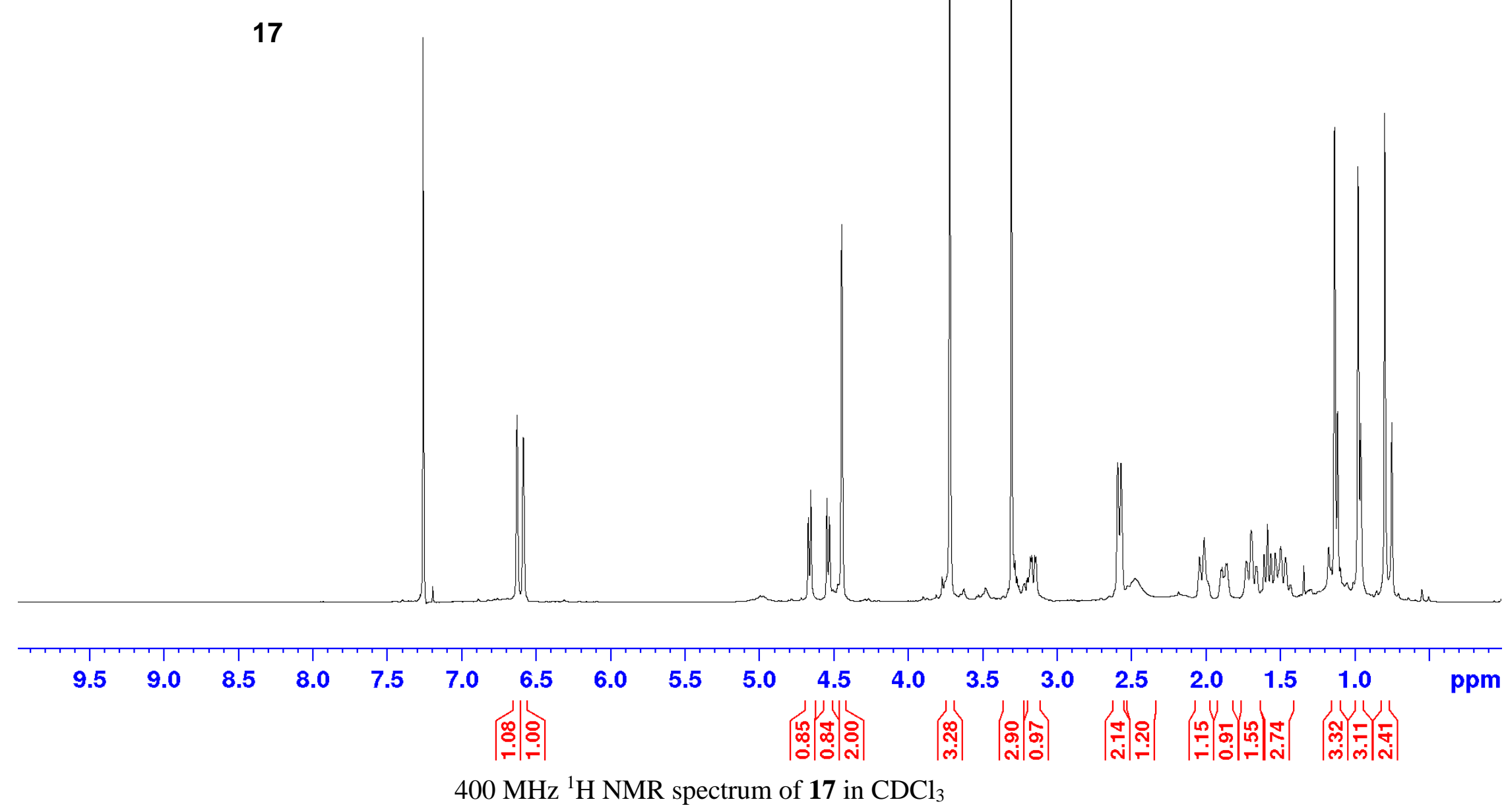




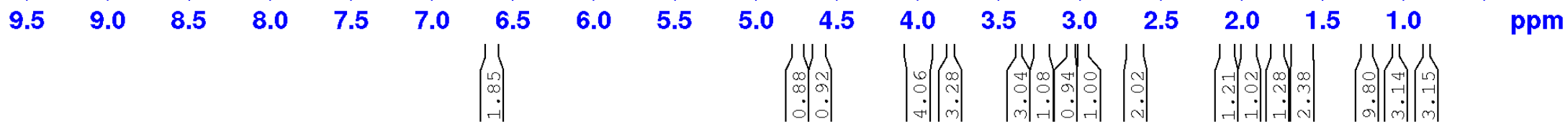

$300 \mathrm{MHz}{ }^{1} \mathrm{H}$ NMR spectrum of 15 in $\mathrm{CDCl}_{3}$ 


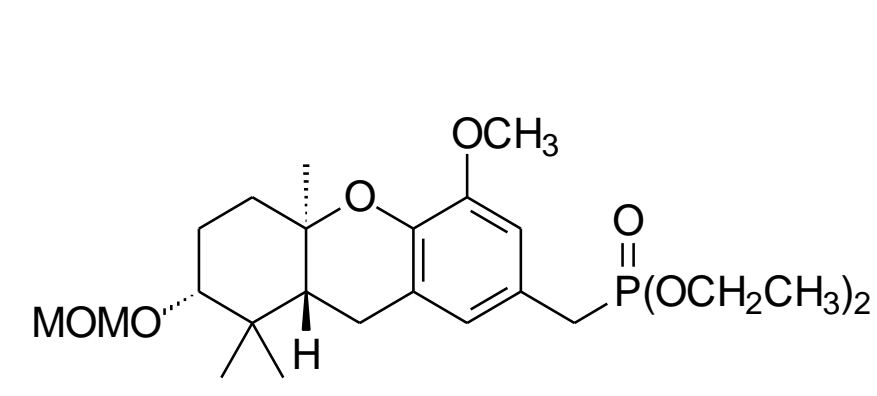

15
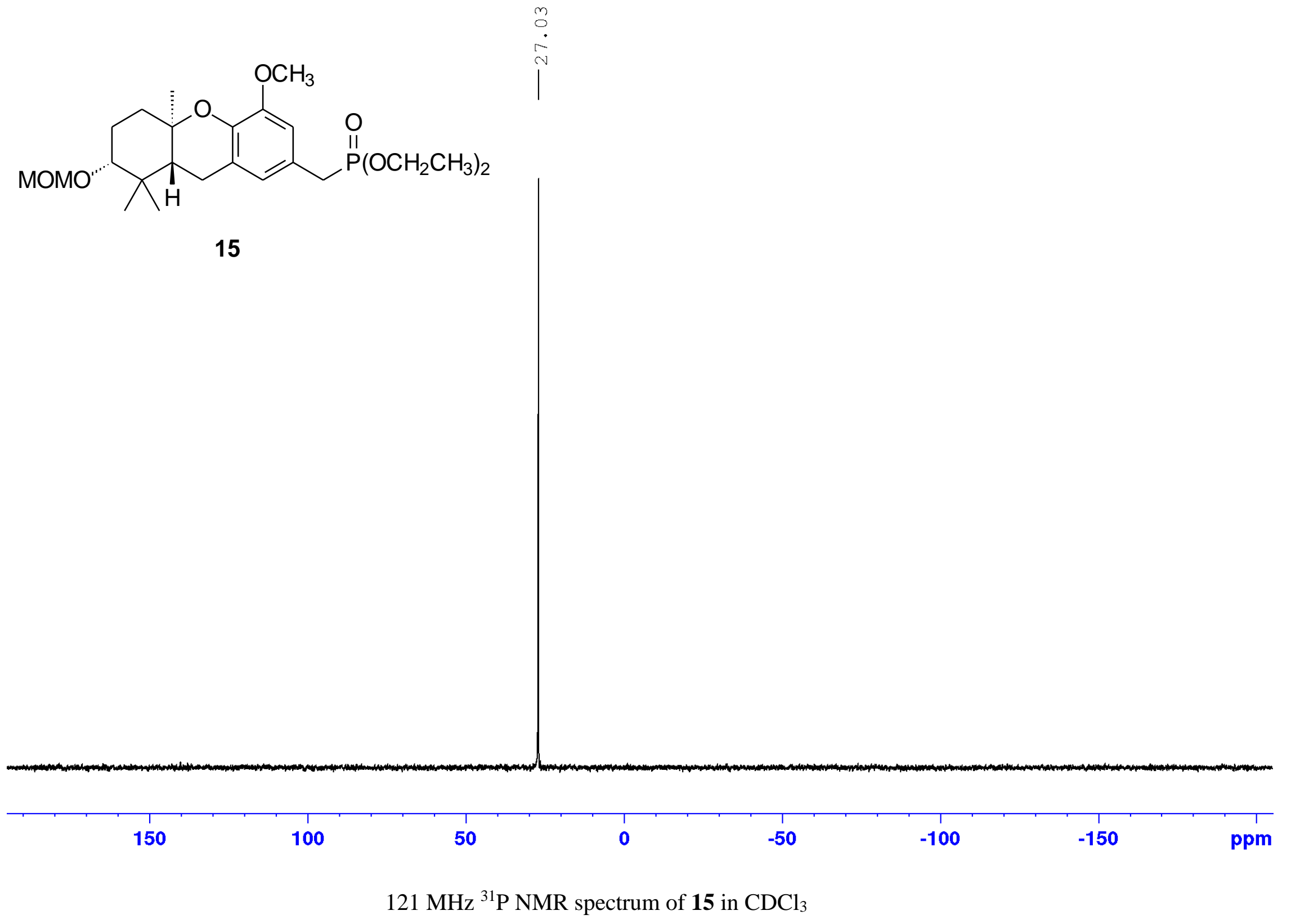


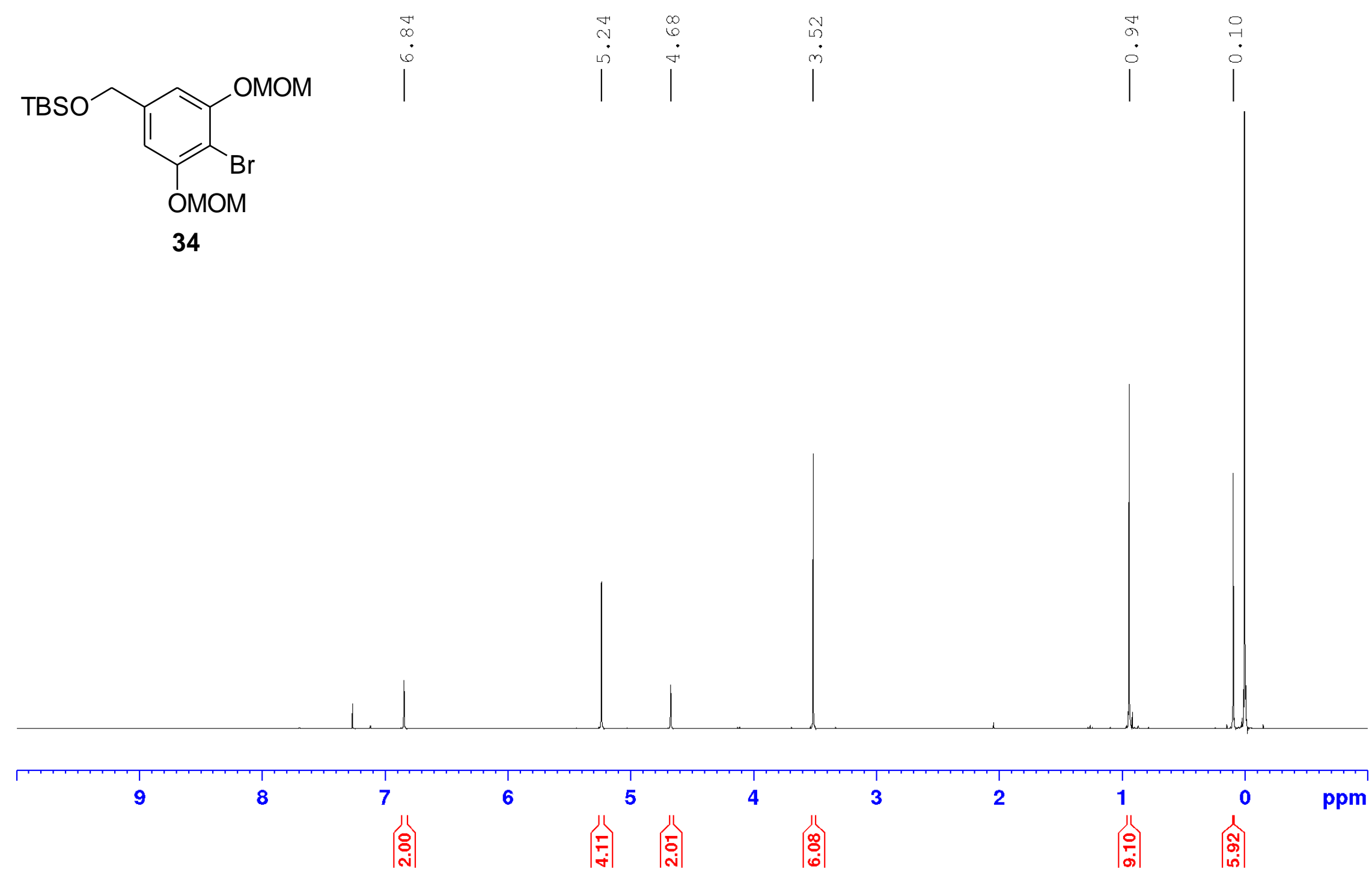

$400 \mathrm{MHz}{ }^{1} \mathrm{H}$ NMR spectrum of 34 in $\mathrm{CDCl}_{3}$ 


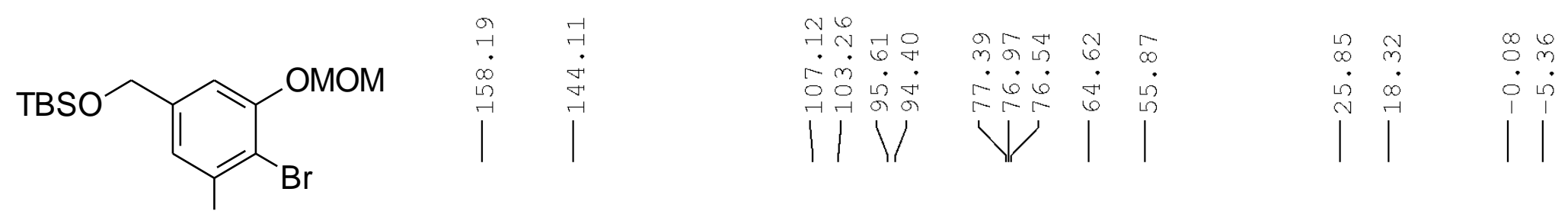

34

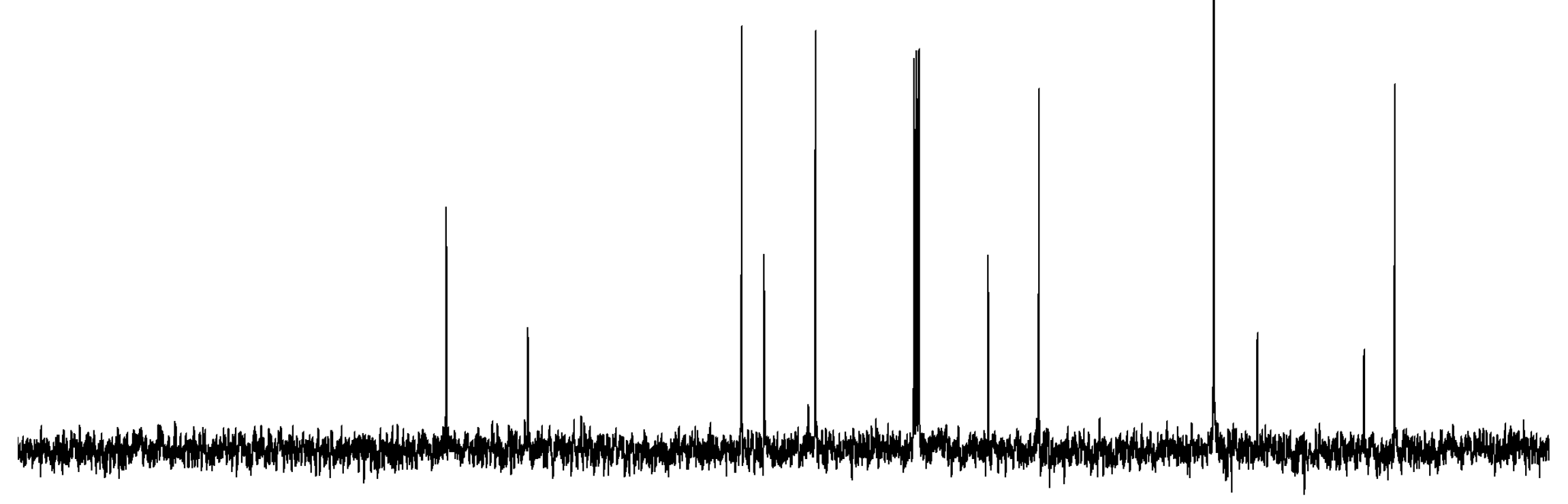

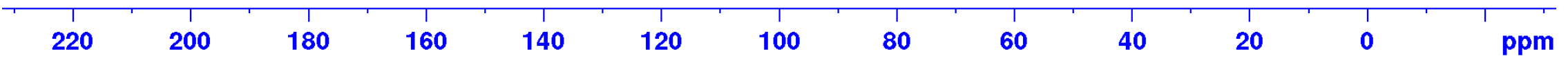

$75 \mathrm{MHz}{ }^{13} \mathrm{C}\left\{{ }^{1} \mathrm{H}\right\}$ NMR spectrum of $\mathbf{3 4}$ in $\mathrm{CDCl}_{3}$ 


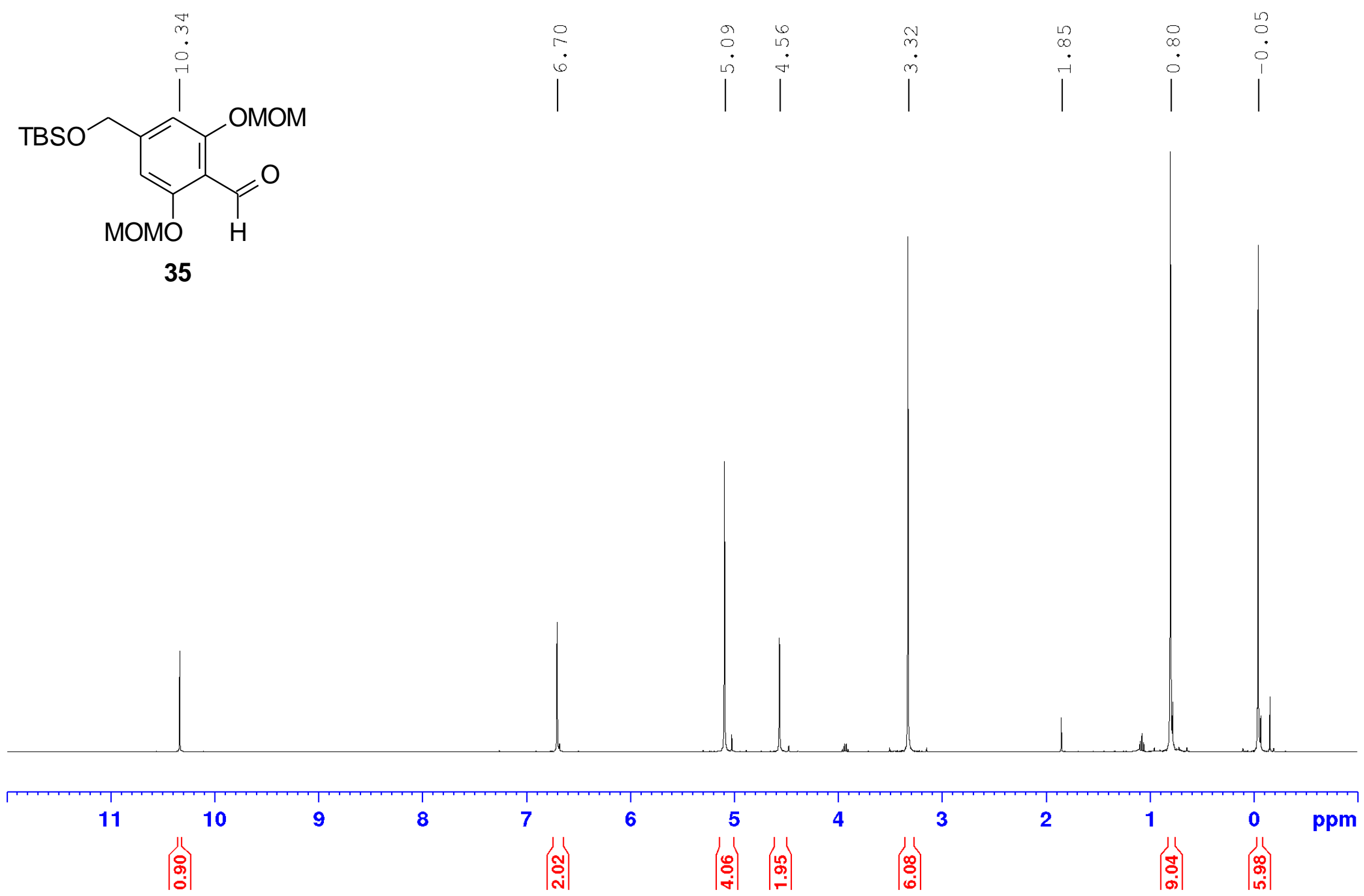

$400 \mathrm{MHz}{ }^{1} \mathrm{H}$ NMR spectrum of 35 in $\mathrm{CDCl}_{3}$ 


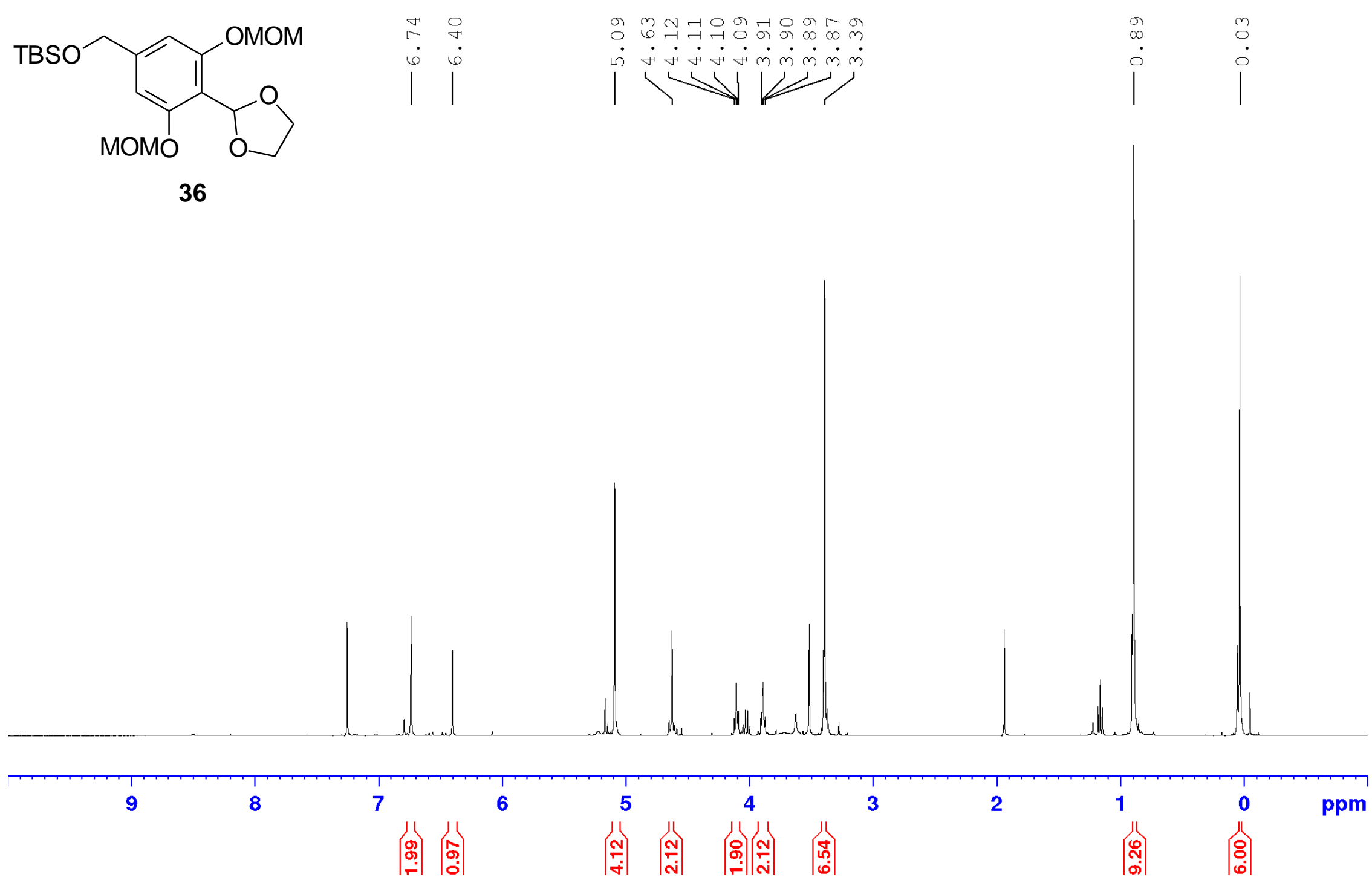

$400 \mathrm{MHz}{ }^{1} \mathrm{H}$ NMR spectrum of $\mathbf{3 6}$ in $\mathrm{CDCl}_{3}$ 

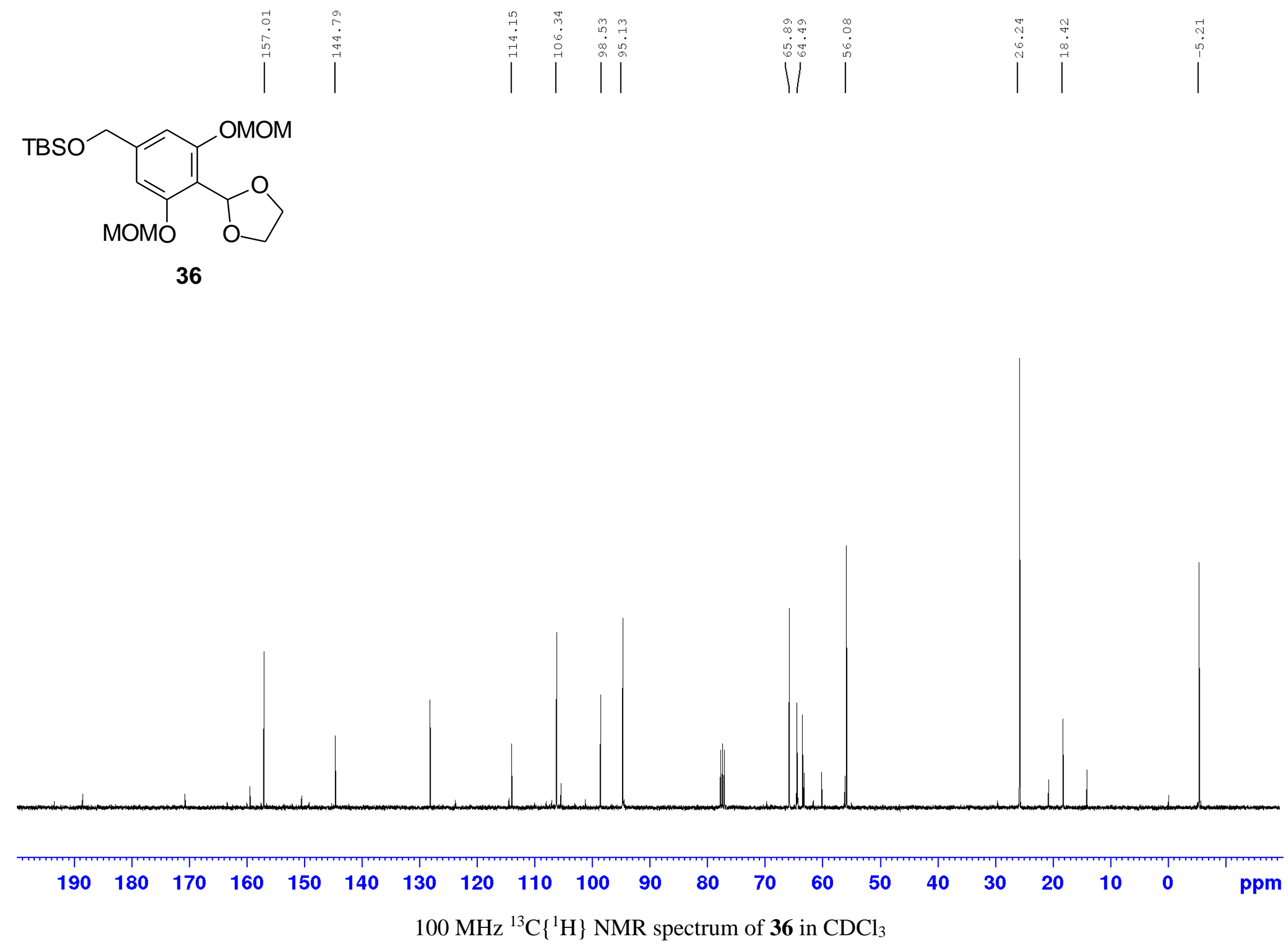


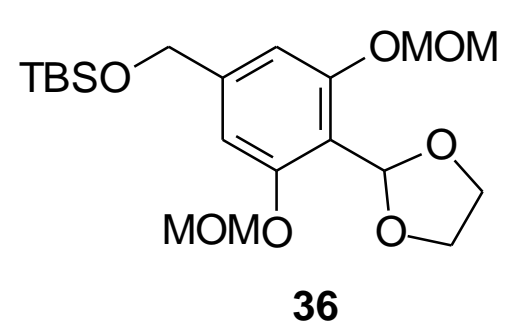

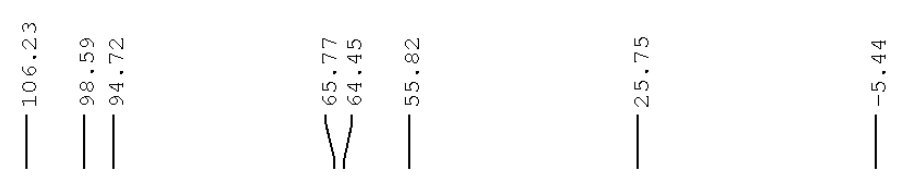

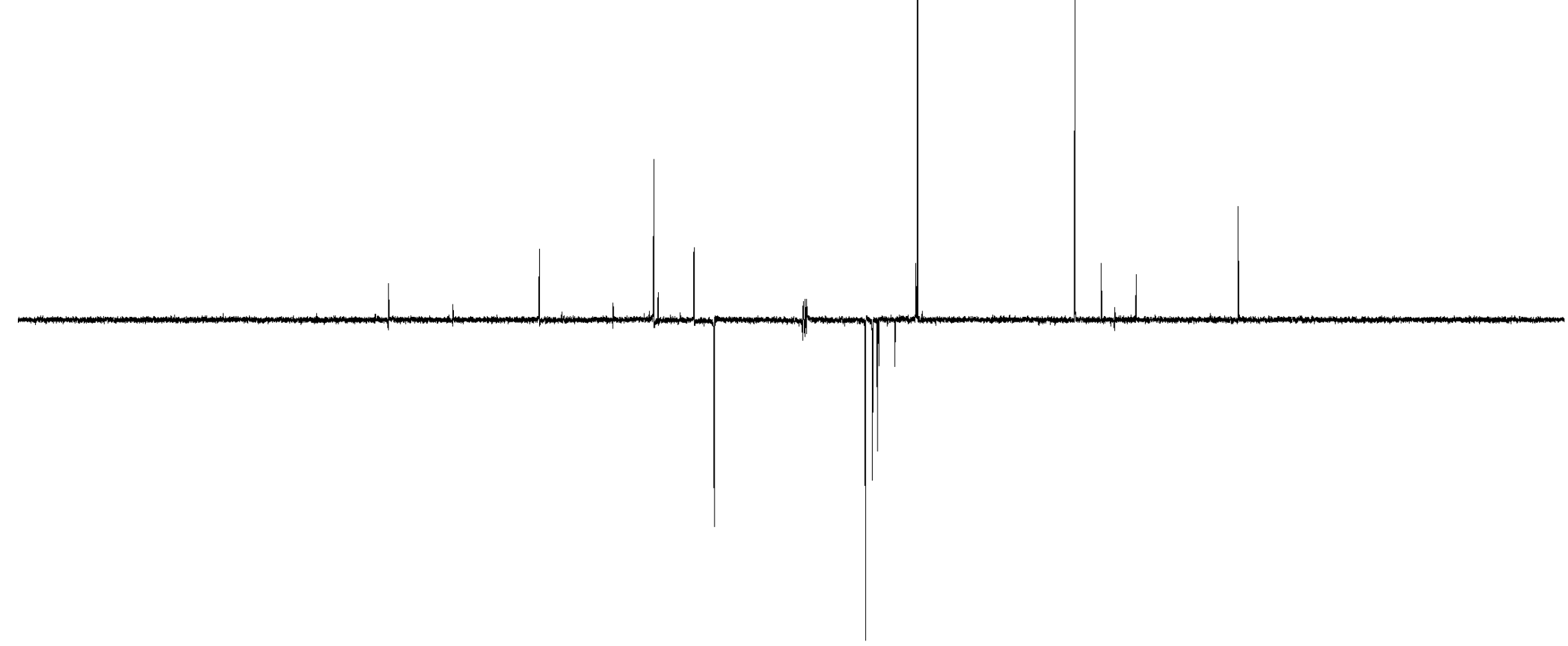

$100 \mathrm{MHz}$ DEPT-135 of $\mathbf{3 6}$ in $\mathrm{CDCl}_{3}$ 


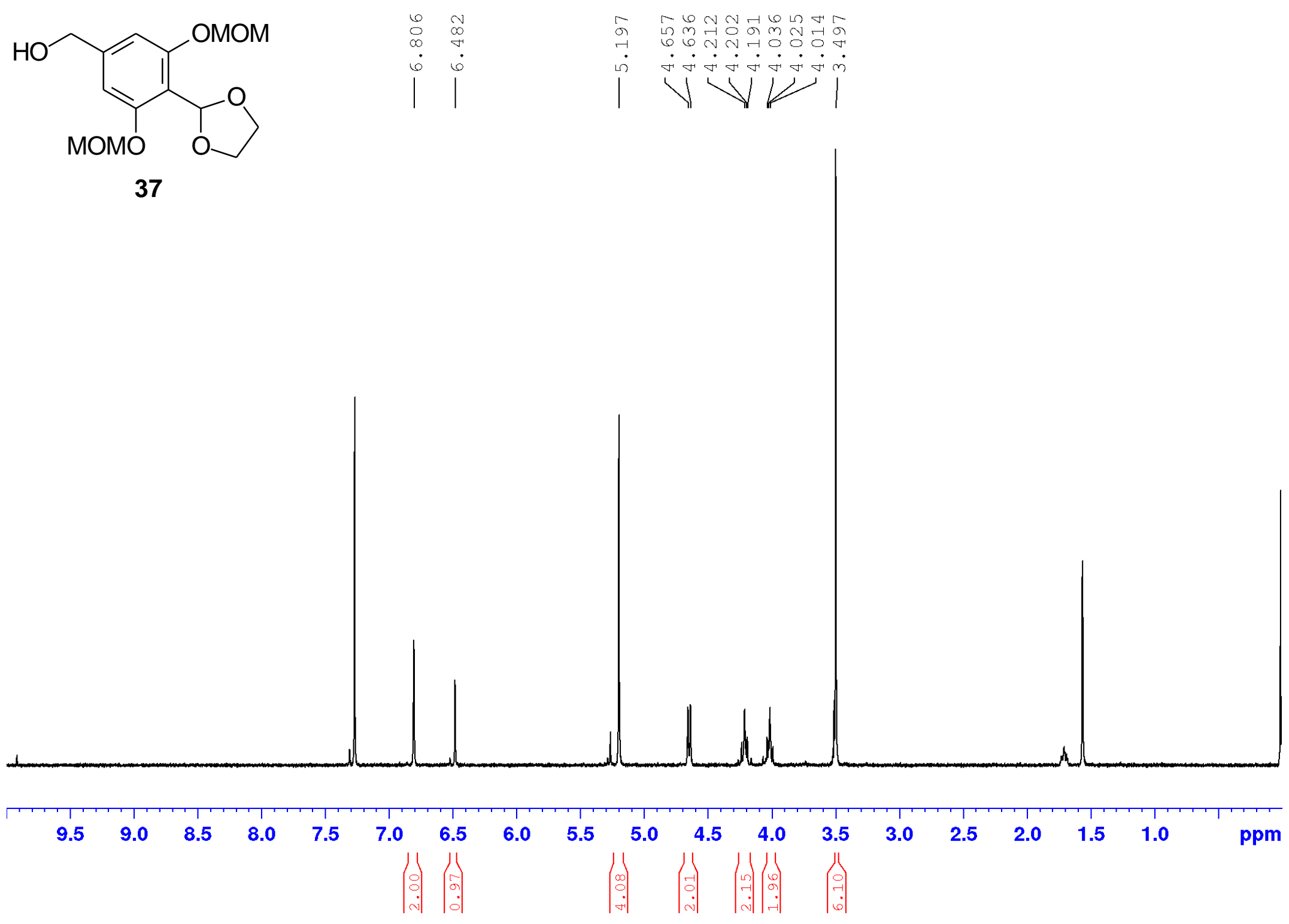

$300 \mathrm{MHz}{ }^{1} \mathrm{H}$ NMR spectrum of $\mathbf{3 7}$ in $\mathrm{CDCl}_{3}$ 


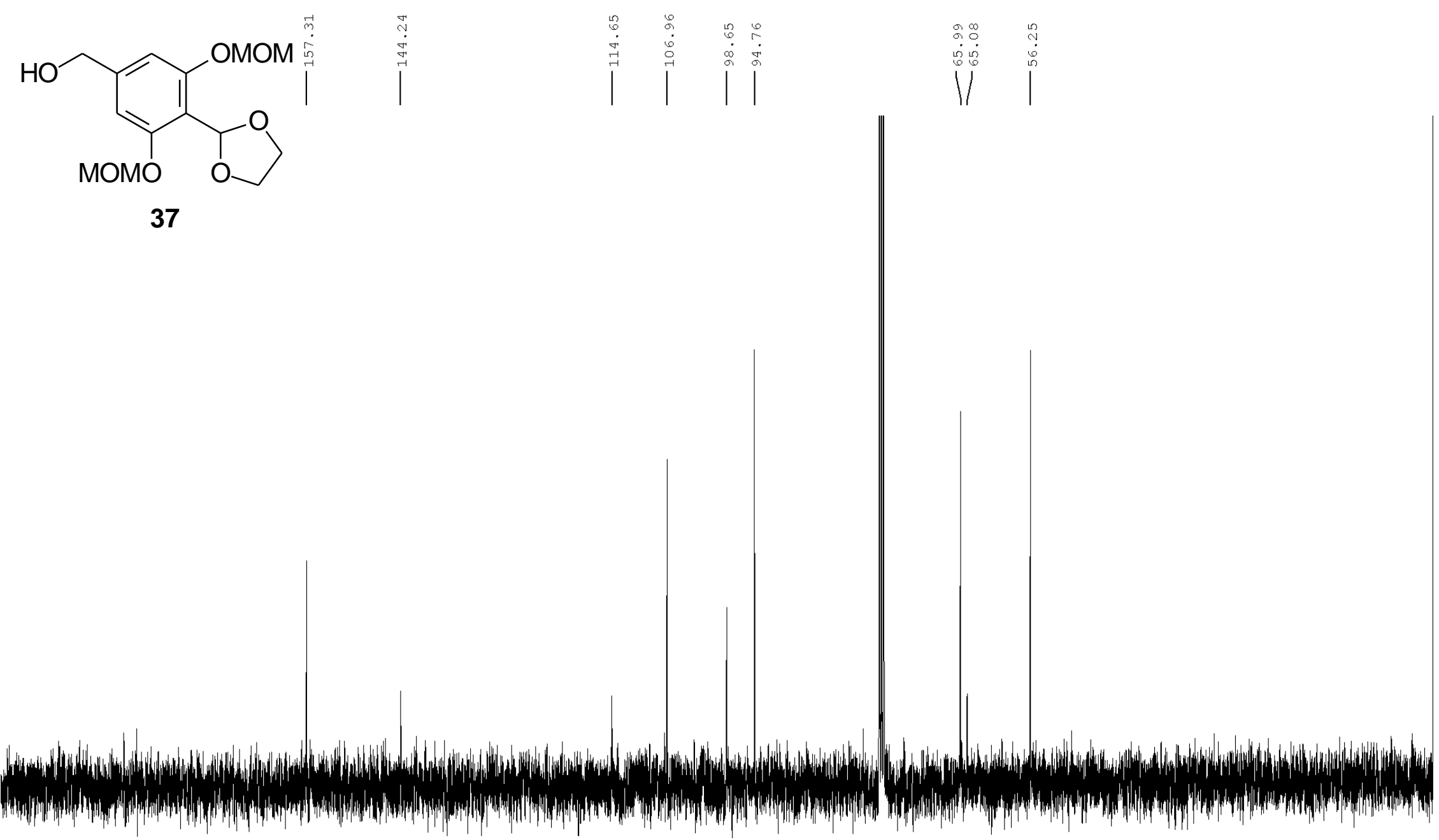

\begin{tabular}{|c|c|c|c|c|c|c|c|c|c|c|c|c|c|c|c|c|c|}
\hline 190 & 180 & 170 & 160 & 150 & 140 & 130 & 120 & 110 & 100 & 90 & 80 & 70 & 60 & 50 & 40 & 30 & 20 \\
\hline
\end{tabular}




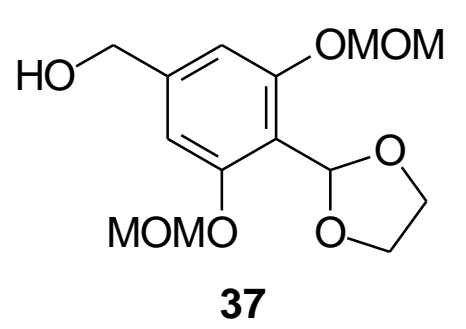

I

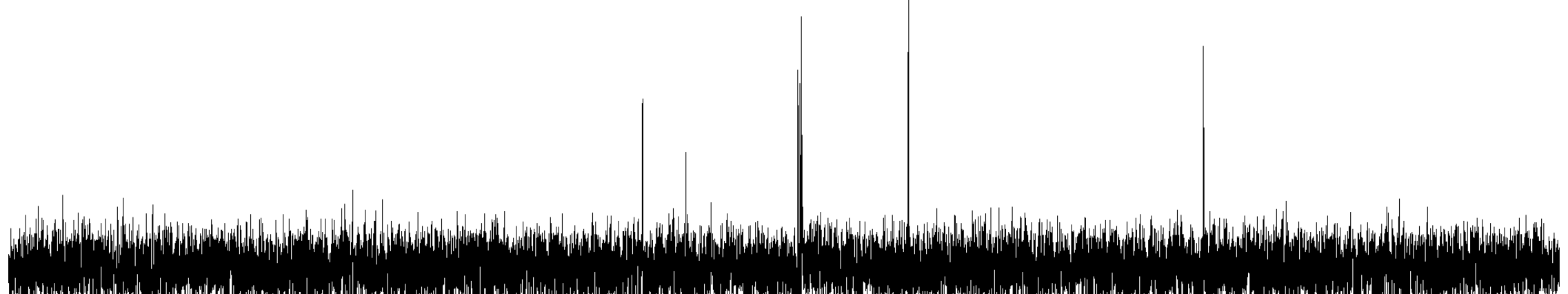

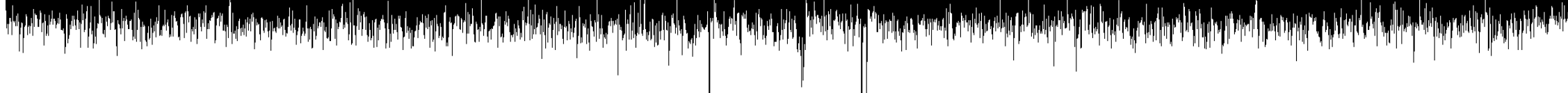

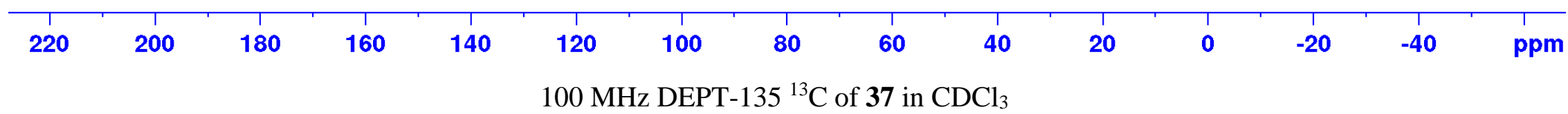




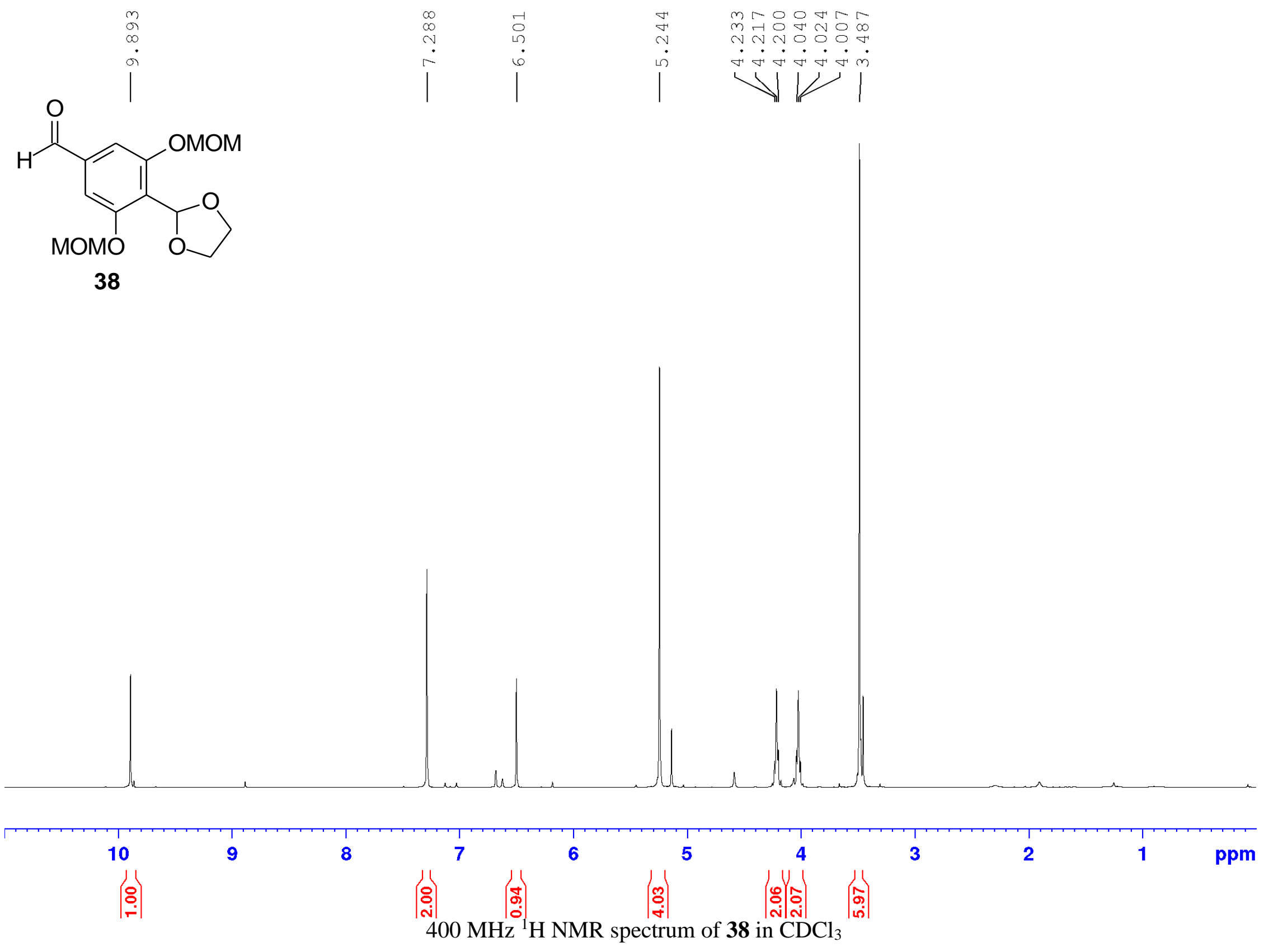




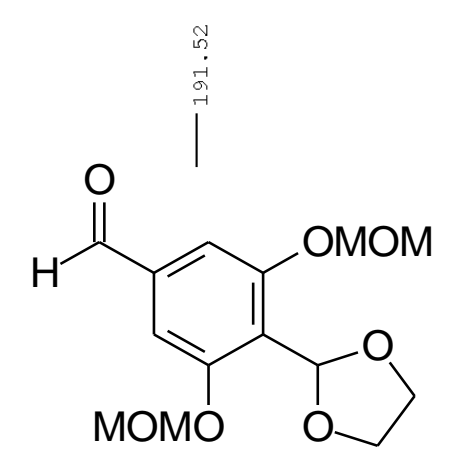

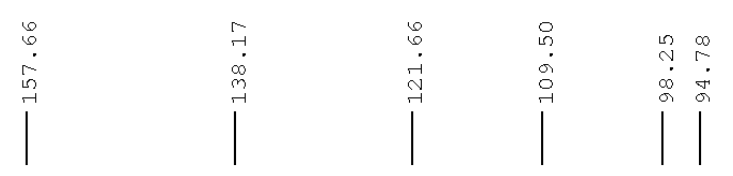

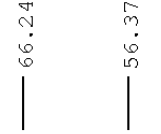

38
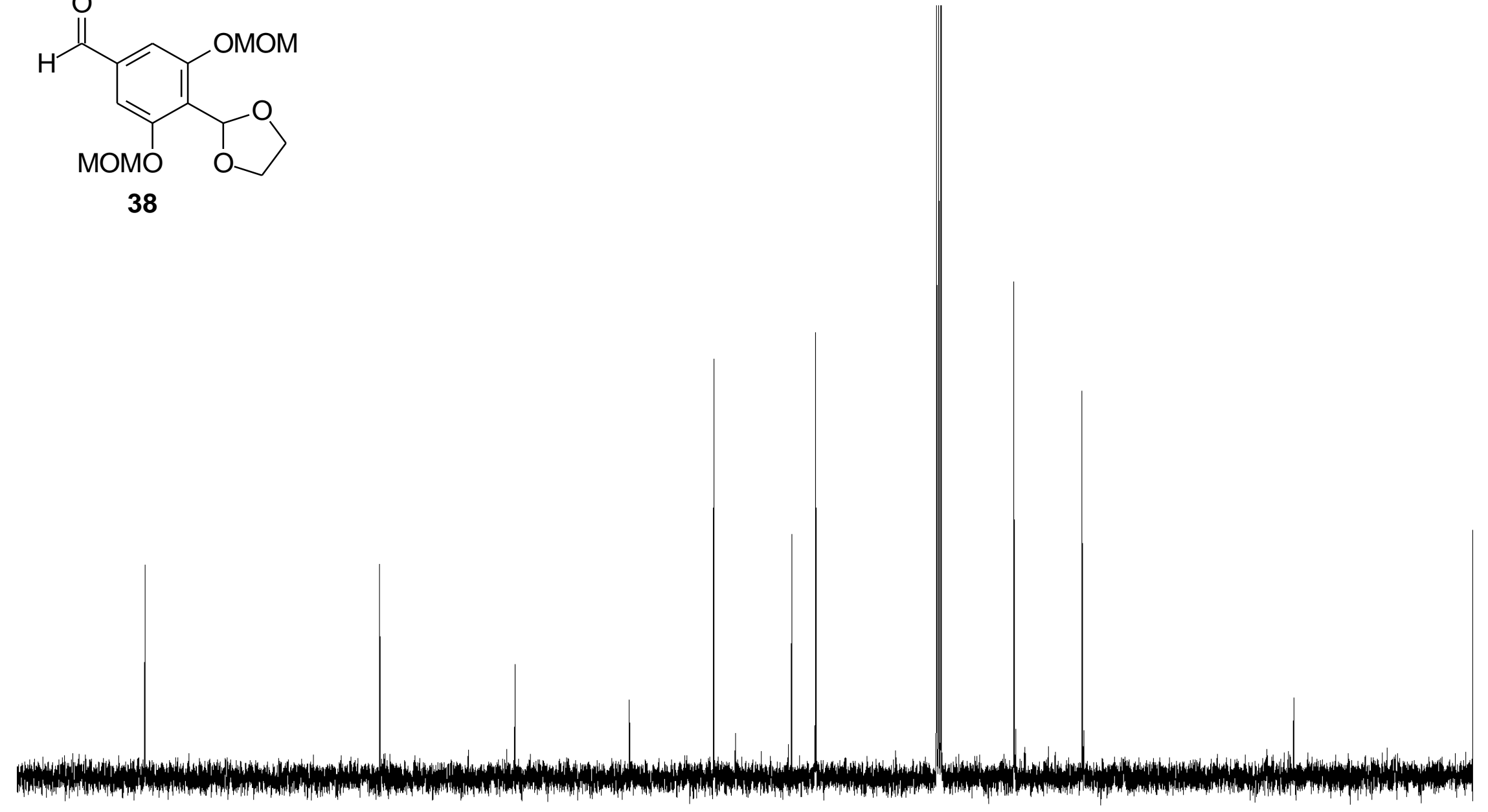

200

$\begin{array}{lll}180 & 170 \quad 160\end{array}$

150

$\begin{array}{lll}140 & 130 & 120\end{array}$

110100

90

80

70

60

50

40

$100 \mathrm{MHz}^{13} \mathrm{C}\left\{{ }^{1} \mathrm{H}\right\}$ NMR spectrum of $\mathbf{3 8}$ in $\mathrm{CDCl}_{3}$ 


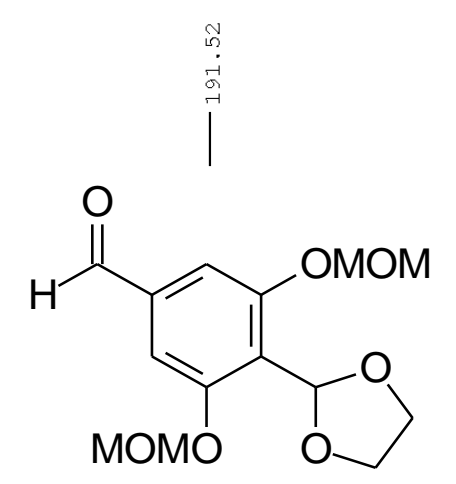

38

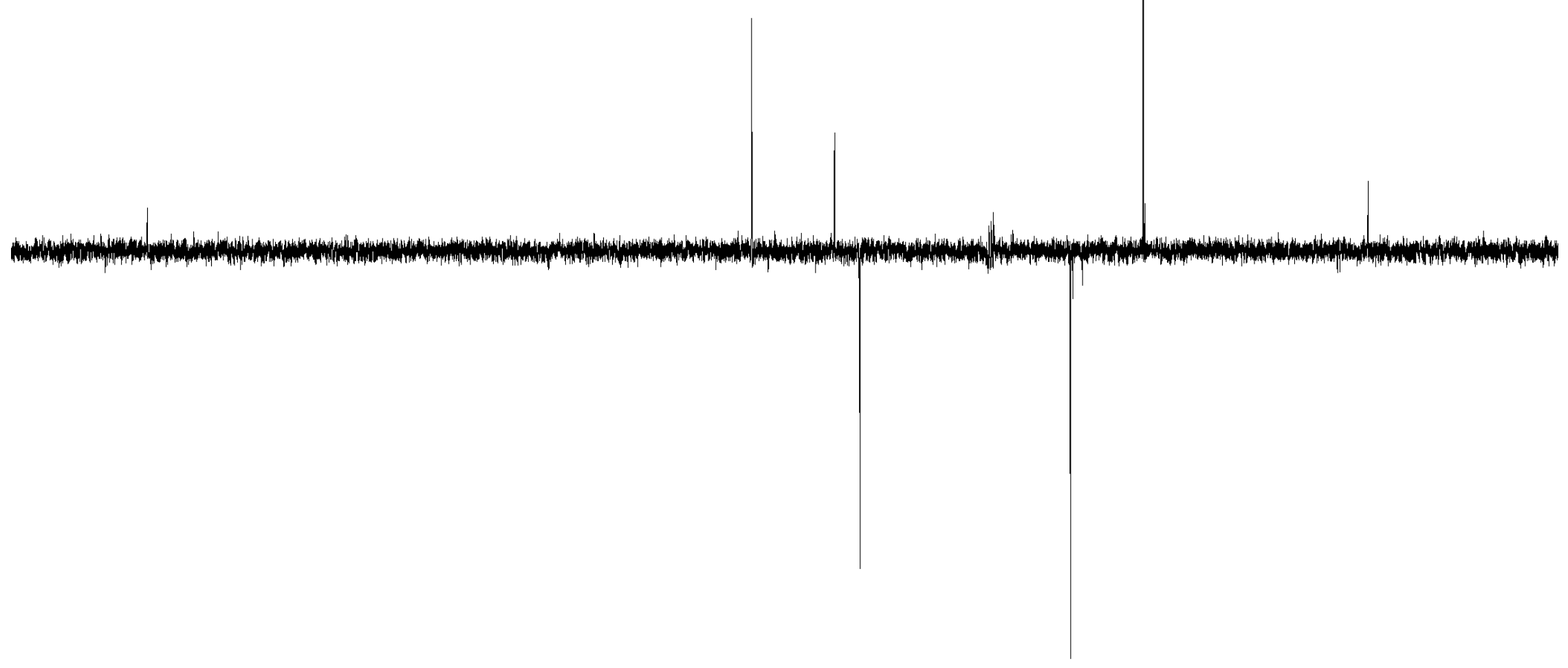

\section{$\begin{array}{lllllllll}150 & 140 & 130 & 120 & 110 & 100 & 90 & 80 & 70\end{array}$}

$100 \mathrm{MHz}$ DEPT-135 NMR spectrum of 38 in $\mathrm{CDCl}_{3}$

ppm 


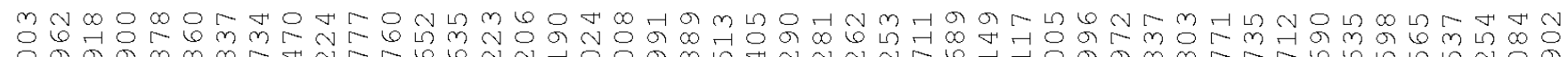
क

26,6606

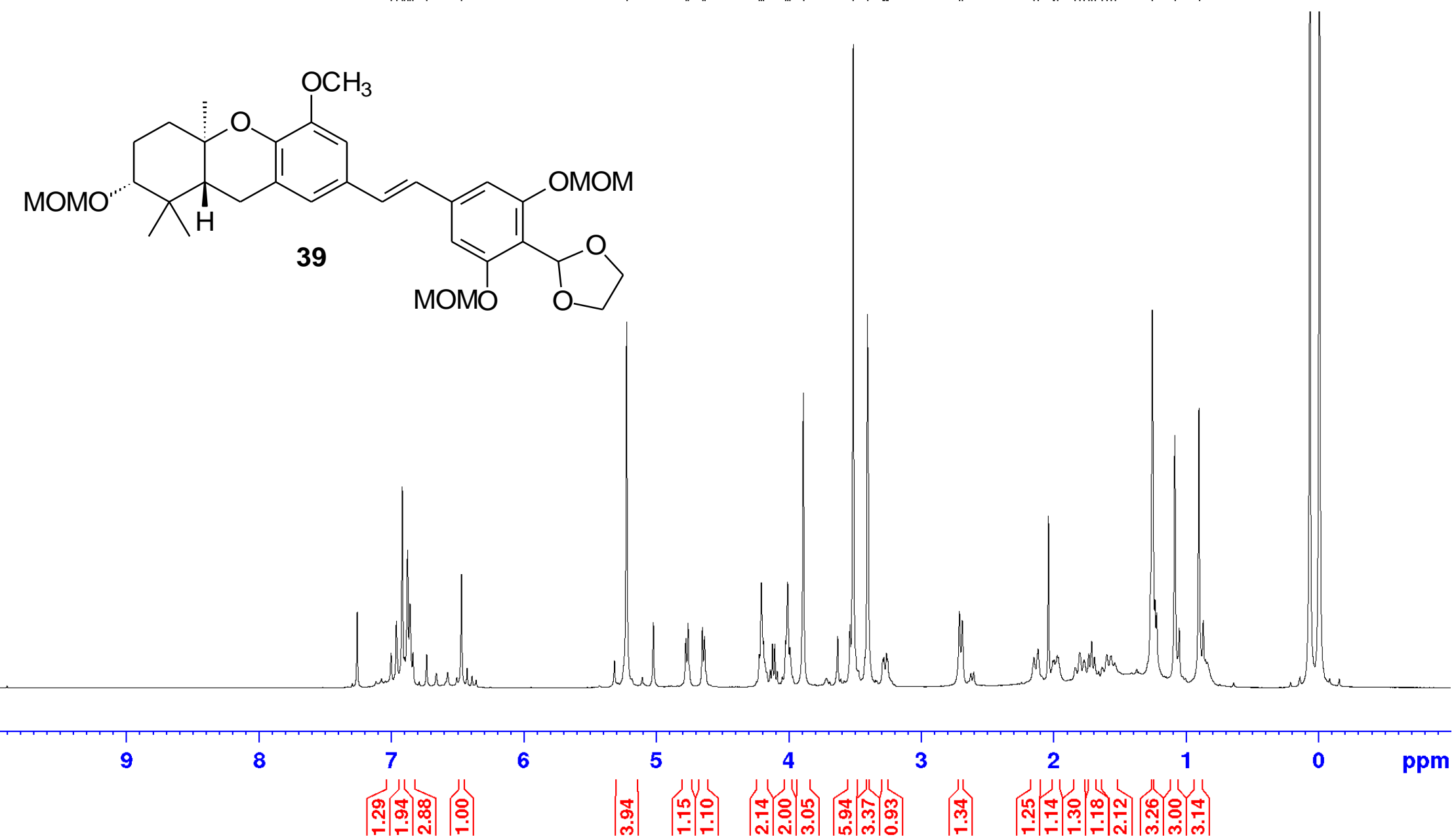

$400 \mathrm{MHz}{ }^{1} \mathrm{H}$ NMR spectrum of 39 in $\mathrm{CDCl}_{3}$ 


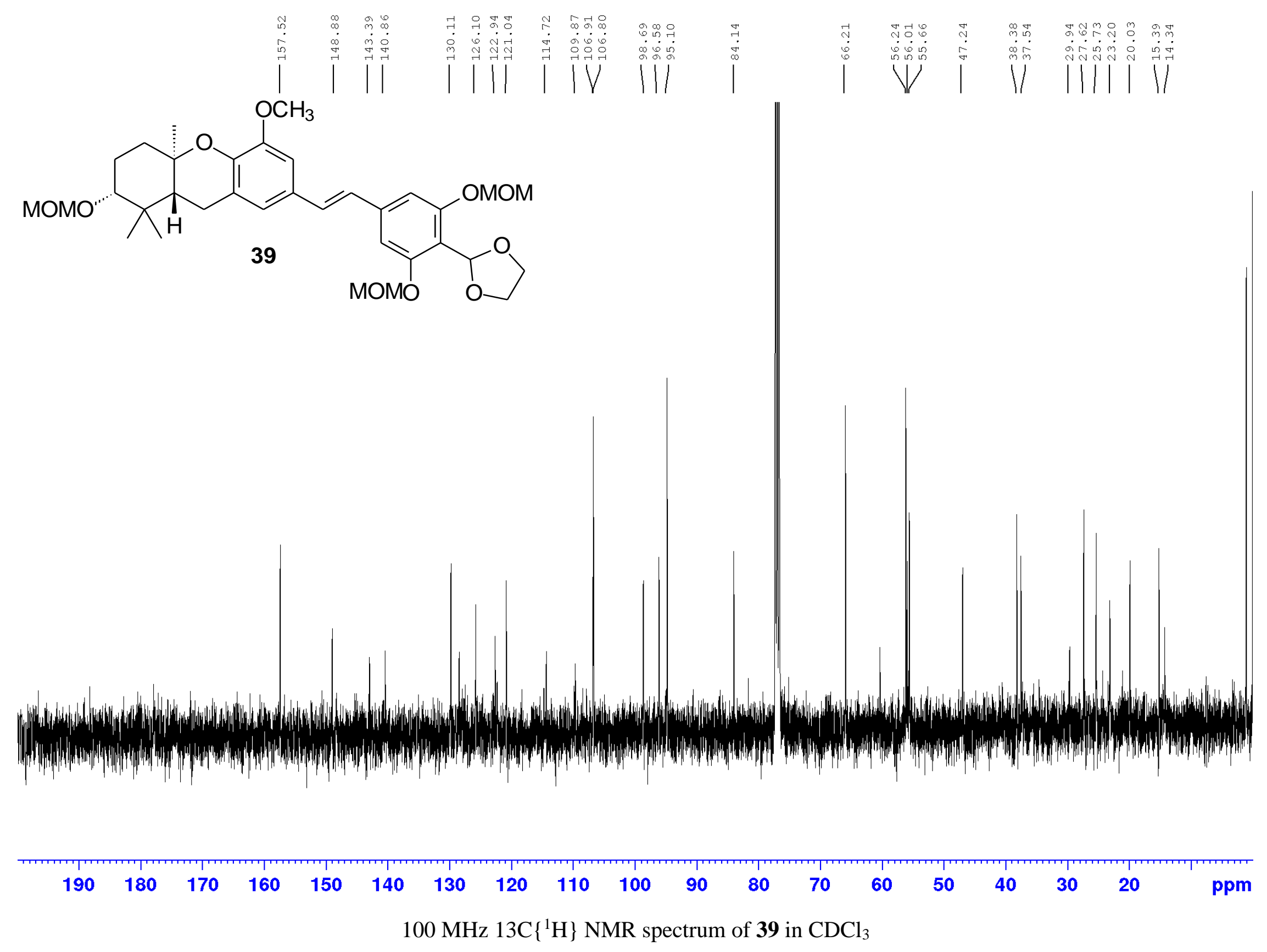



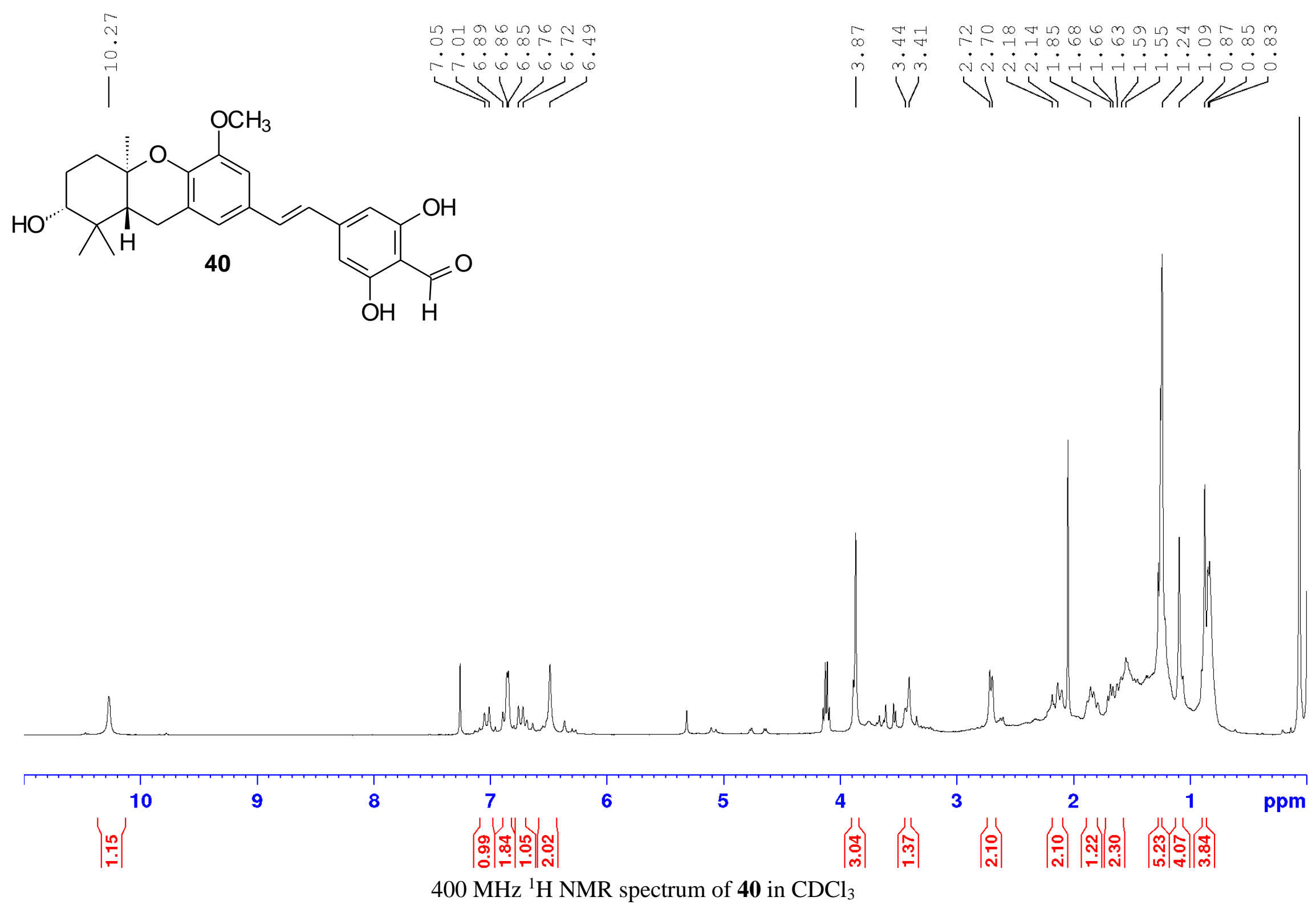


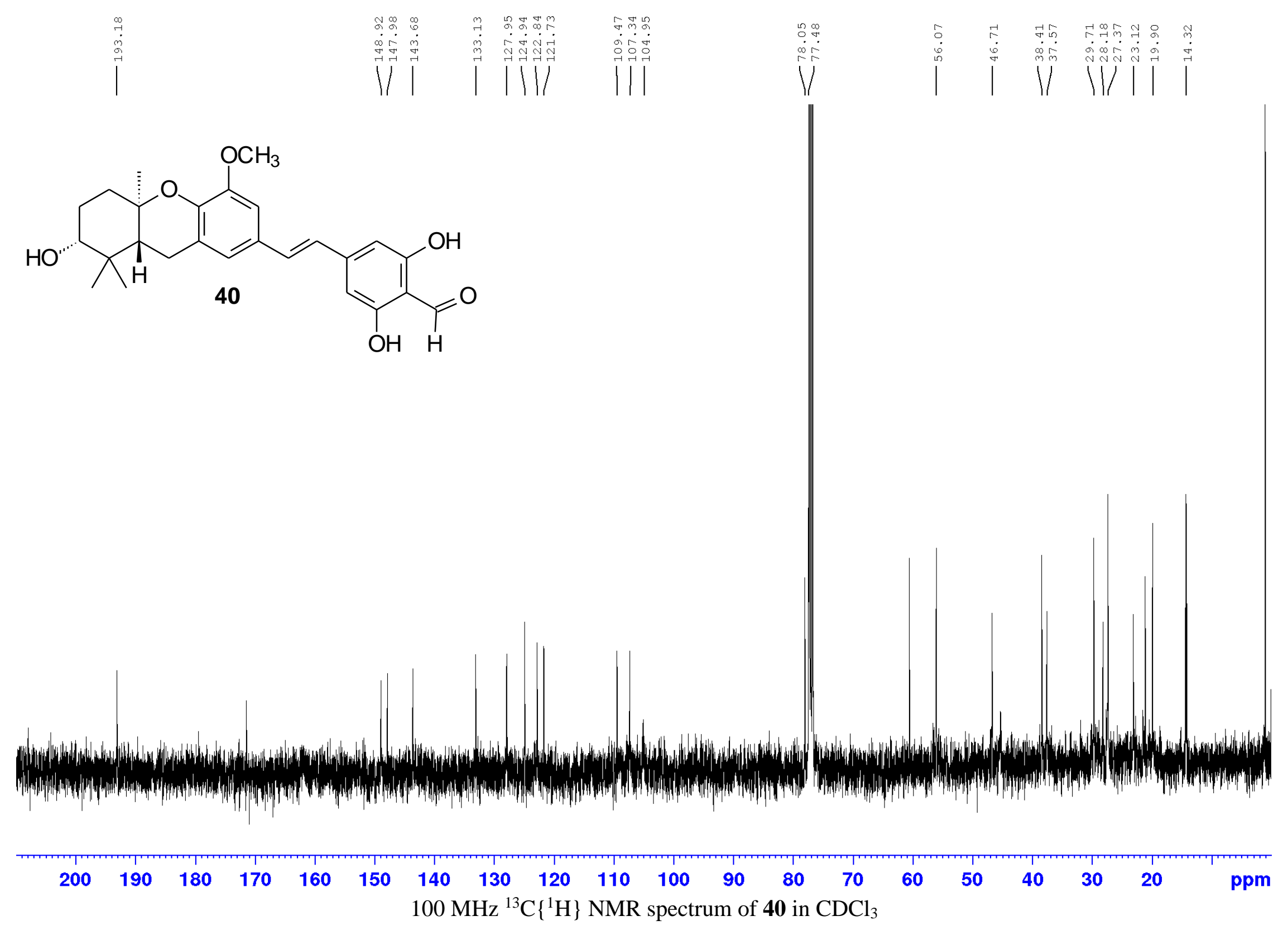




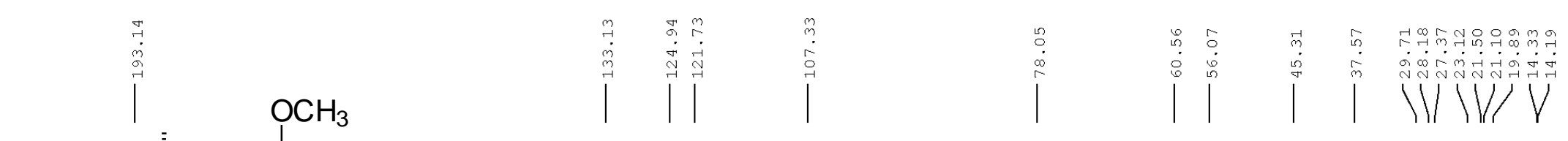<smiles>Cc1cc(/C=C/c2cc(O)c(C=O)c(O)c2)cc2c1OC1CCC(O)C(C)(C)C1C2</smiles>

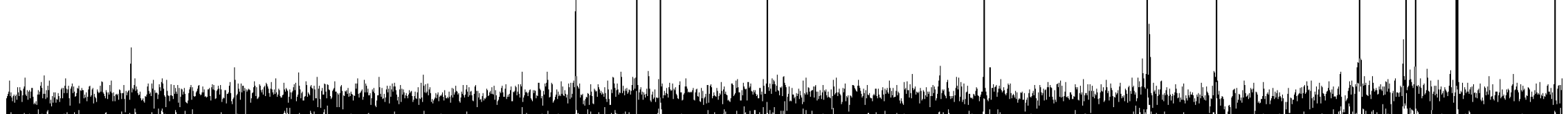

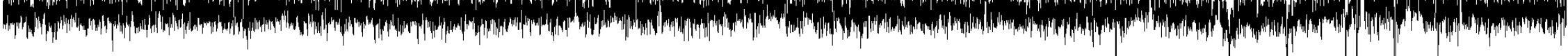

$100 \mathrm{MHz}$ DEPT-135 NMR spectrum of $\mathbf{4 0}$ in $\mathrm{CDCl}_{3}$ 


\section{Dose Response Curves}

\section{Leukemia}

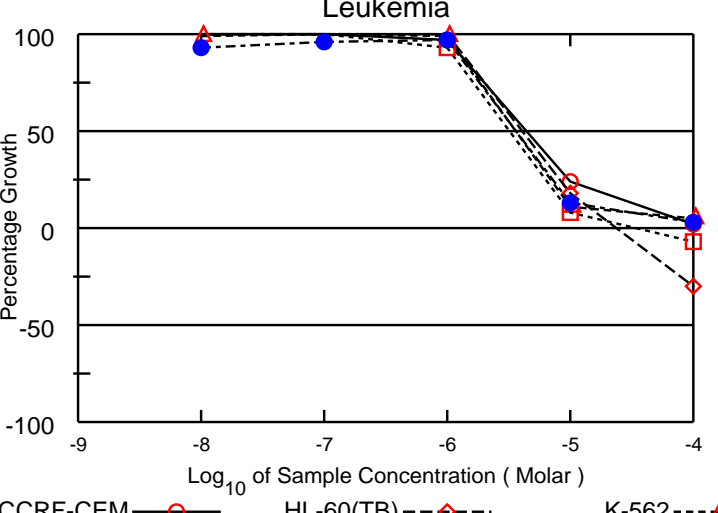

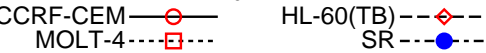

CNS Cancer

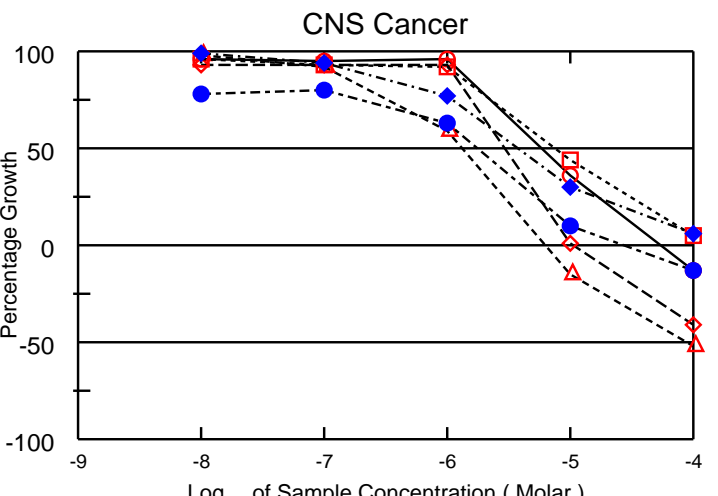

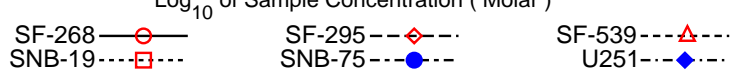

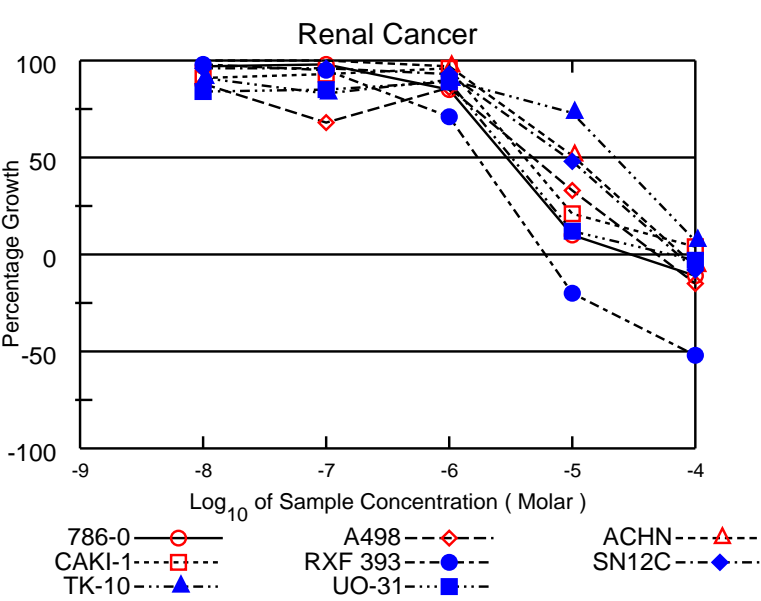

Non-Small Cell Lung Cancer

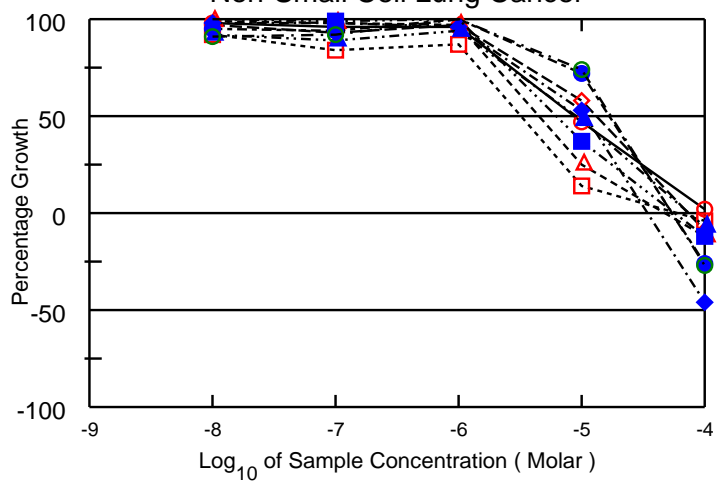

A549/ATCC - $-\quad$ EKVX--- - HOP-62--- $\Delta-$

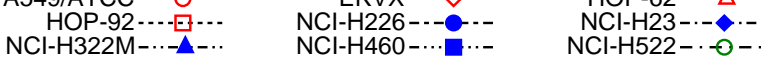

Melanoma

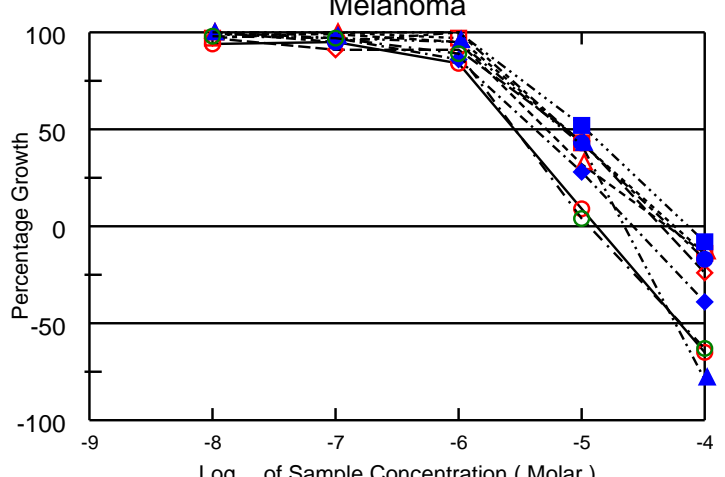

$\log _{10}$ of Sample Concentration (Molar)

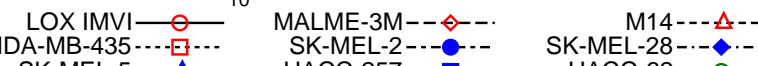

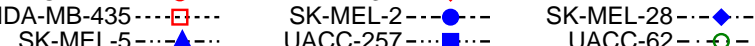

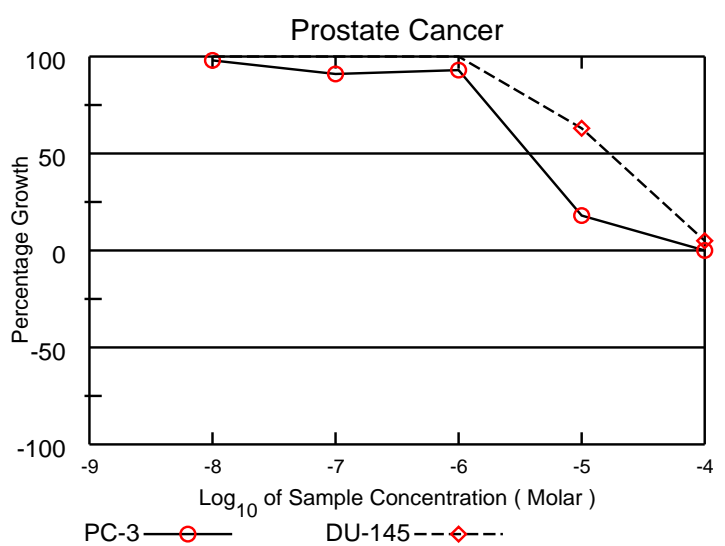

Test Date: December 09, 2019

\section{Colon Cancer}

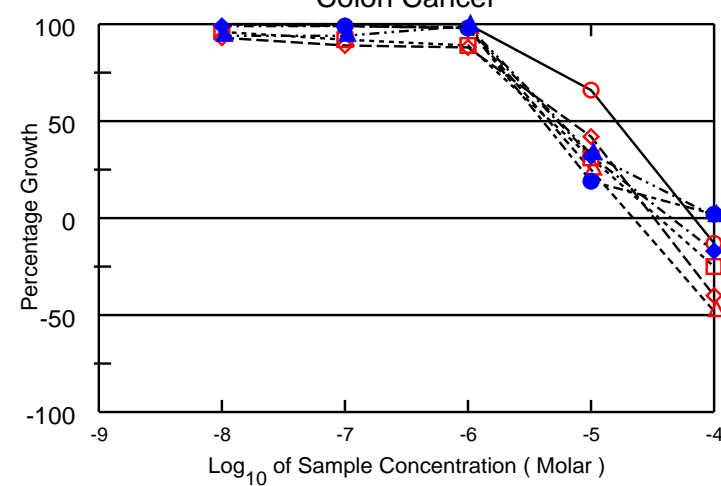

COLO 205- - HCC-2998-- $\leadsto-. \quad$ HCT-116--.A-.. HCT-15...... HT29-.-.

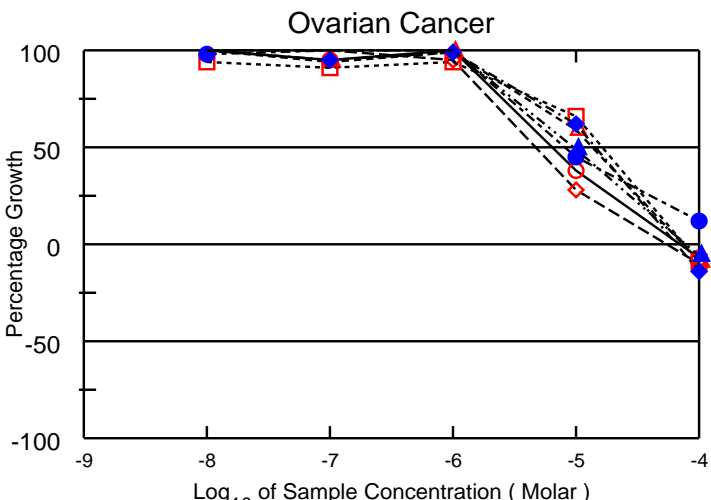

IGROV1- - OVCAR-3-- - -. OVCAR-4---A-

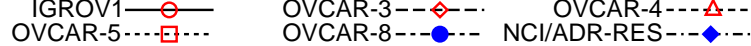
SK-OV-3-...-...

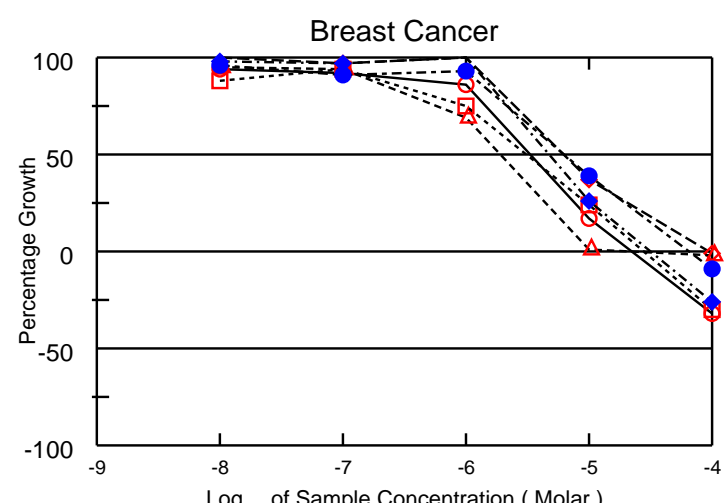

$\log _{10}$ of Sample Concentration ( Molar )

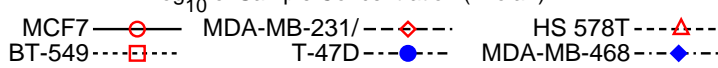


National Cancer Institute Developmental Therapeutics Program Mean Graphs

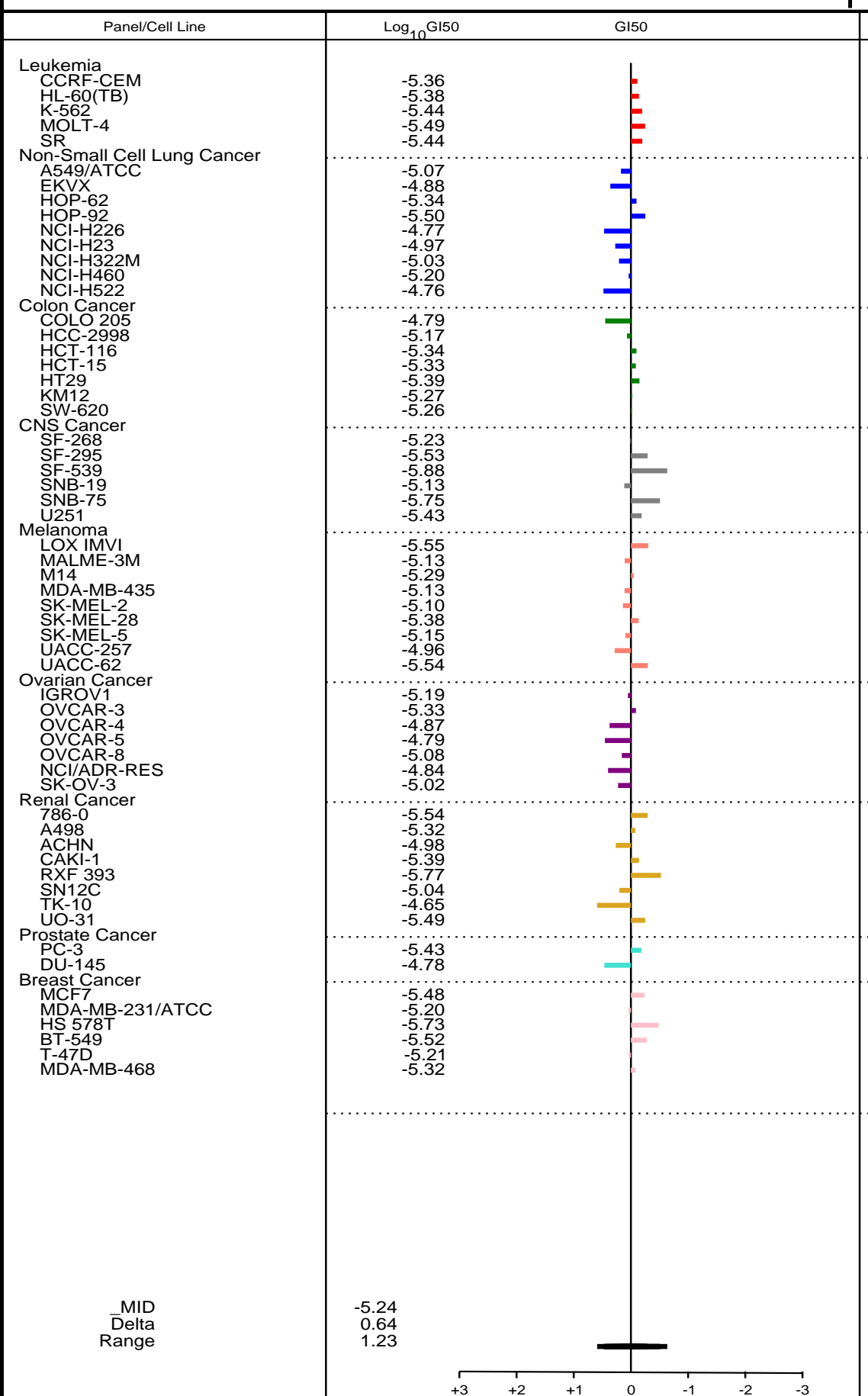

NSC : D - 819974/1

Units :Molar

Report Date :January 13, 2020

Test Date :December 09, 2019

\begin{tabular}{l|ll}
$\log _{10}$ TGI & $\log _{10}$ LC50 & LC50
\end{tabular}

$>-4.00$
$>\quad-4$.
$>-4$
$>\quad-4$.
$>-4.00$

-4.00
-4.62
-4.00
-4.46
-4.00
-4.00
-4.14

-4.14
-4.32
-4.21
-4.27
-4.46
-.43

-4.13
-4.24
-4.27
-4.47

-4.17
-4.49
-4.66
-4.45
-4.00

$>$\begin{aligned} &-4.00 \\ &$>-4.34 \\ &$\hline-4.00\end{aligned}

-4.26
-4.98
-5.21
-4.00
-4.07
$>-4.00$

$>\quad-4.00$

-4.26
-5.98
-5.21
-4.00
-4.57
-4.00
-4.88
-4.35
-4.24
-4.24
-4.59
-4.65
-4.14

-4.65
-4.94
-4.94

-4.16
-4.27
-4.12
-4.00
-4.08
-4.18

-4.18
-4.10

-4.54
-4.52
-4.10
-5.02
-5.22
$>-5.02$

$>>-4.40$

$>\quad-4.00$

-4.65
-4.03
-4.79
-4.56
-4.19
-451

$-4.32$

-4.32
0.9
1.22

=-

$=$

-4.00
-4.00
-4.00
-4.00
-4

3.4 .00
$>-4.00$
3

$\begin{array}{lll}3 & -4.00 \\ > & -4.00 \\ 3 & -4.00 \\ 3 & 3\end{array}$

$\begin{array}{ccc}3 & -4.00 \\ 3 & -4.00 \\ 3 & -4.00 \\ 3 & -400\end{array}$

$\begin{array}{lll}3 & -4.00 \\ > & -4.00\end{array}$

$>\begin{gathered}-4.00 \\ >-4.00 \\ 3\end{gathered}$

$>\begin{array}{lll}> & -4.00 \\ > & -4.00\end{array}$

$>\quad-4.00$

$>-4.00$

$\begin{array}{ll}> & -4.00 \\ > & -4.06 \\ > & -4.00 \\ > & -000\end{array}$

\begin{tabular}{ll}
$>$ & -4.00 \\
$>$ & -4.00 \\
$>$ & -4.00 \\
\hline & -4.21
\end{tabular}

$>\begin{array}{ll}-4.21 \\ > & -4.00 \\ 3 & -400 \\ 3 & -4.00\end{array}$

$\begin{array}{ll}> & -4.00 \\ > & -4.00 \\ > & -4.00 \\ 3 & -4.24\end{array}$

\begin{tabular}{ll}
$>$ & -4.00 \\
$>$ & -4.24 \\
& -4.00 \\
\hline & -4.00
\end{tabular}

$>-4.00$

$>\begin{array}{ll}> & -4.00 \\ > & -4.00 \\ 3 & -4.00\end{array}$

$\begin{array}{lll} & \\ > & -4.00 \\ > & -4.00 \\ > & -4.00\end{array}$

$>-4.00$

$\begin{array}{ll}3 & -4.00 \\ & -4.00 \\ & -4.00 \\ 3 & -400\end{array}$

$>\quad-4.00$

$>\quad-4.00$

$>\begin{gathered}3.000 \\ >-400\end{gathered}$

$\begin{array}{lll}> & -4.00 \\ > & -4.00 \\ > & -4.00 \\ > & -4.00\end{array}$

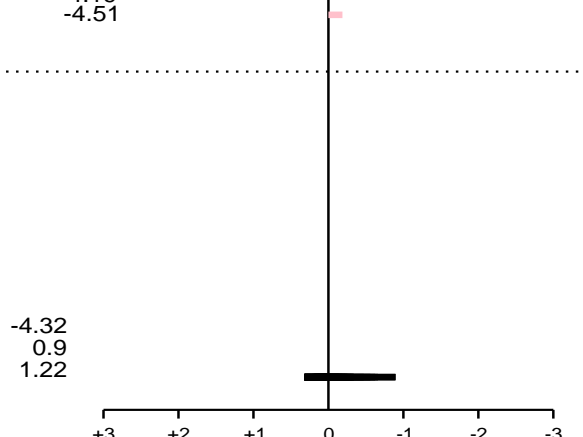

-4.01
0.23

0.24

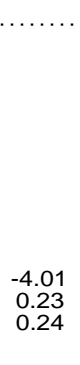

EXP. ID :1912NS94

0


<smiles></smiles>

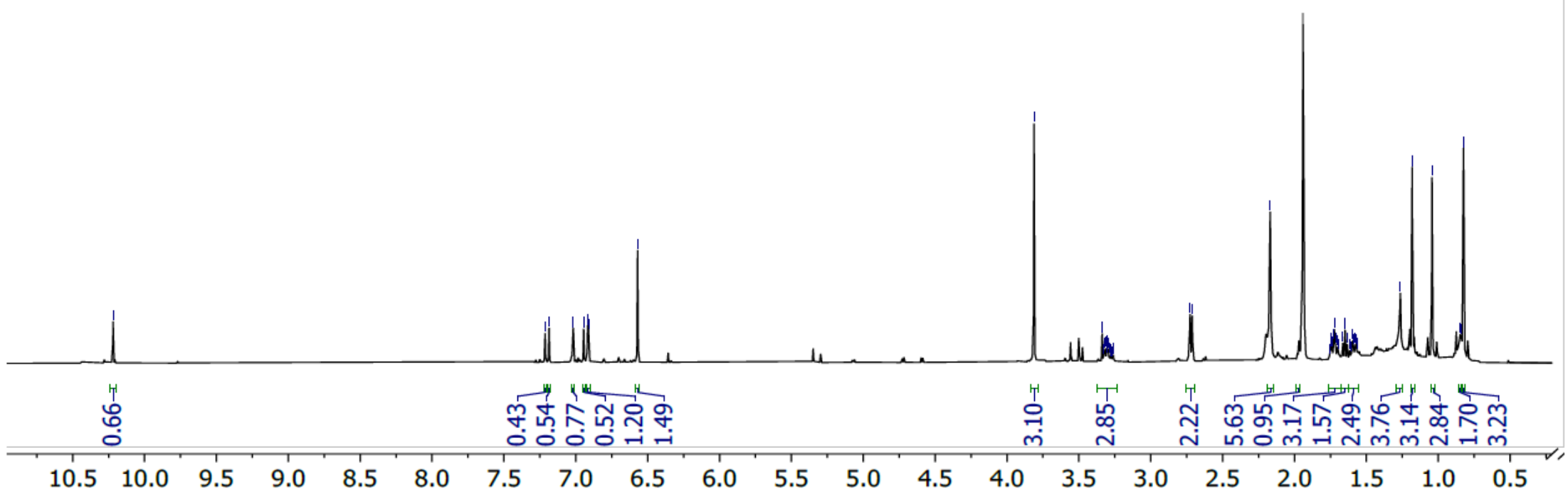

$400 \mathrm{MHz}{ }^{1} \mathrm{H}$ NMR spectrum of $\mathbf{4 1}$ in $\mathrm{CD}_{3} \mathrm{CN}$ 


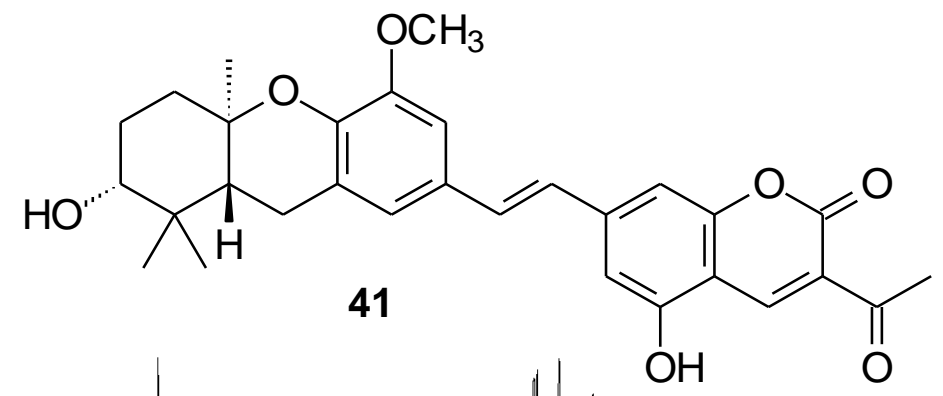

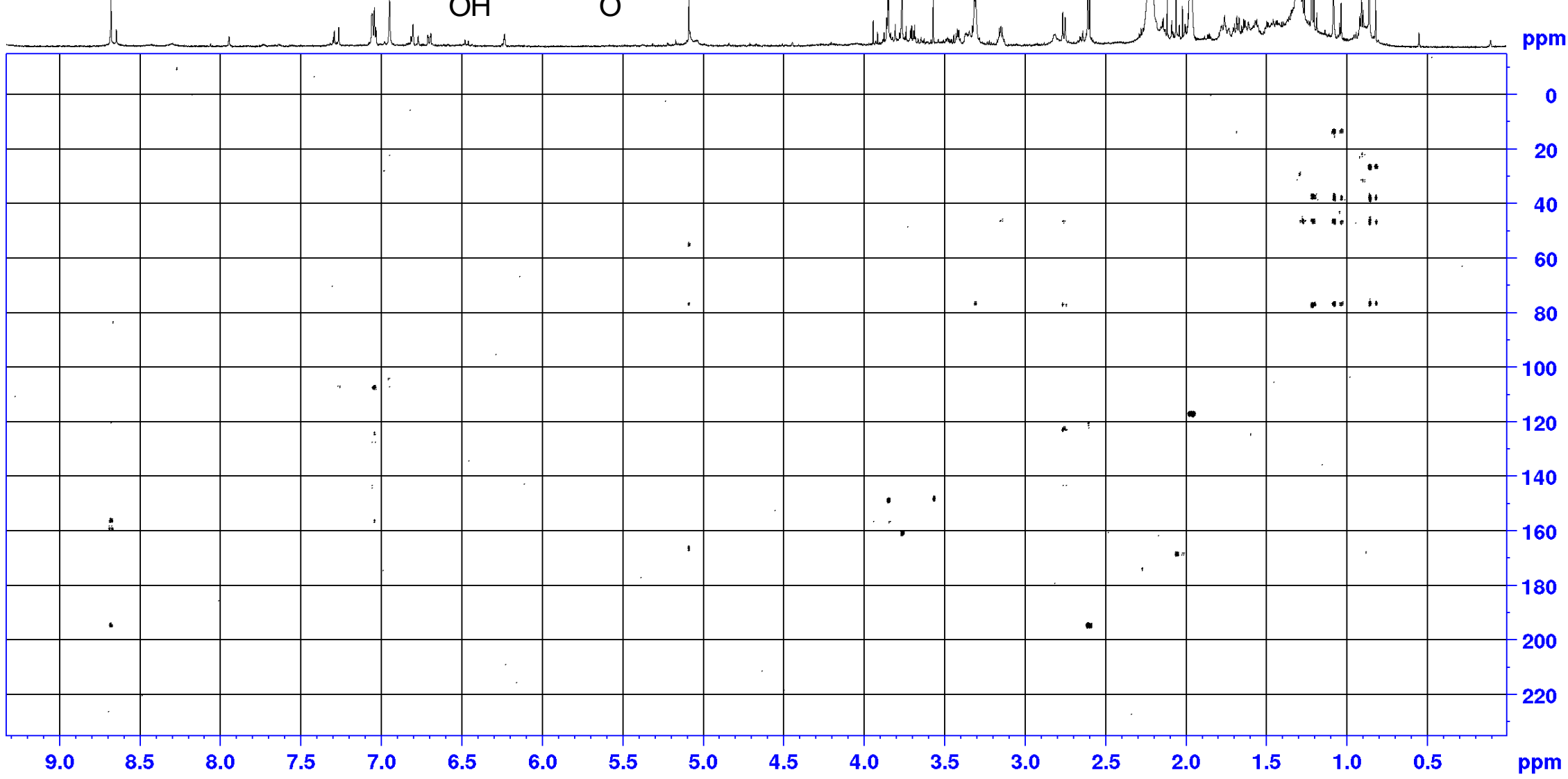

$600 \mathrm{MHz} 2 \mathrm{D}$ HMBC spectrum of $\mathbf{4 1}$ in $\mathrm{CD}_{3} \mathrm{CN}$ 


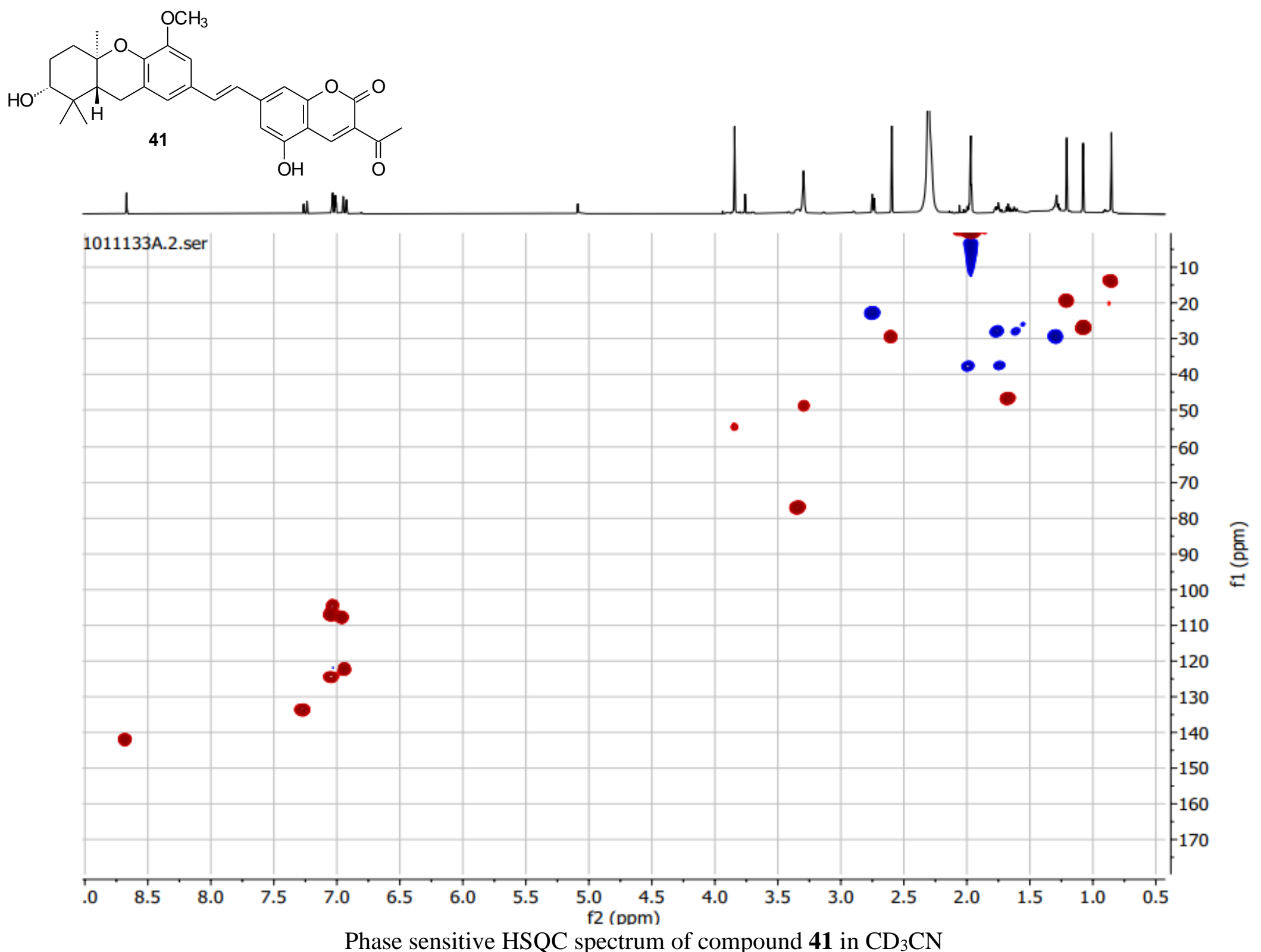



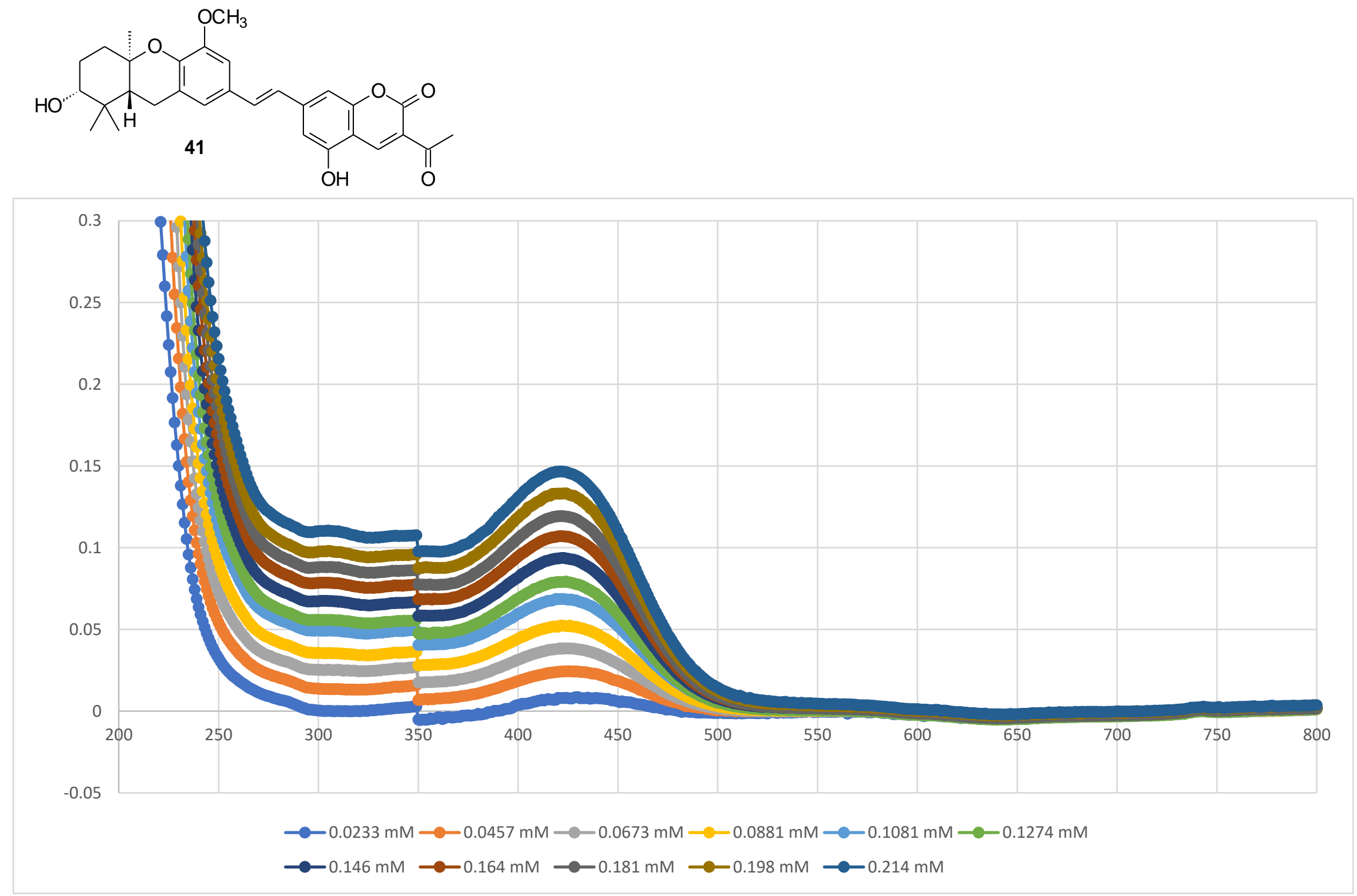

Absorption spectrum of compound $\mathbf{4 1}$ in $\mathrm{EtOH}$ 

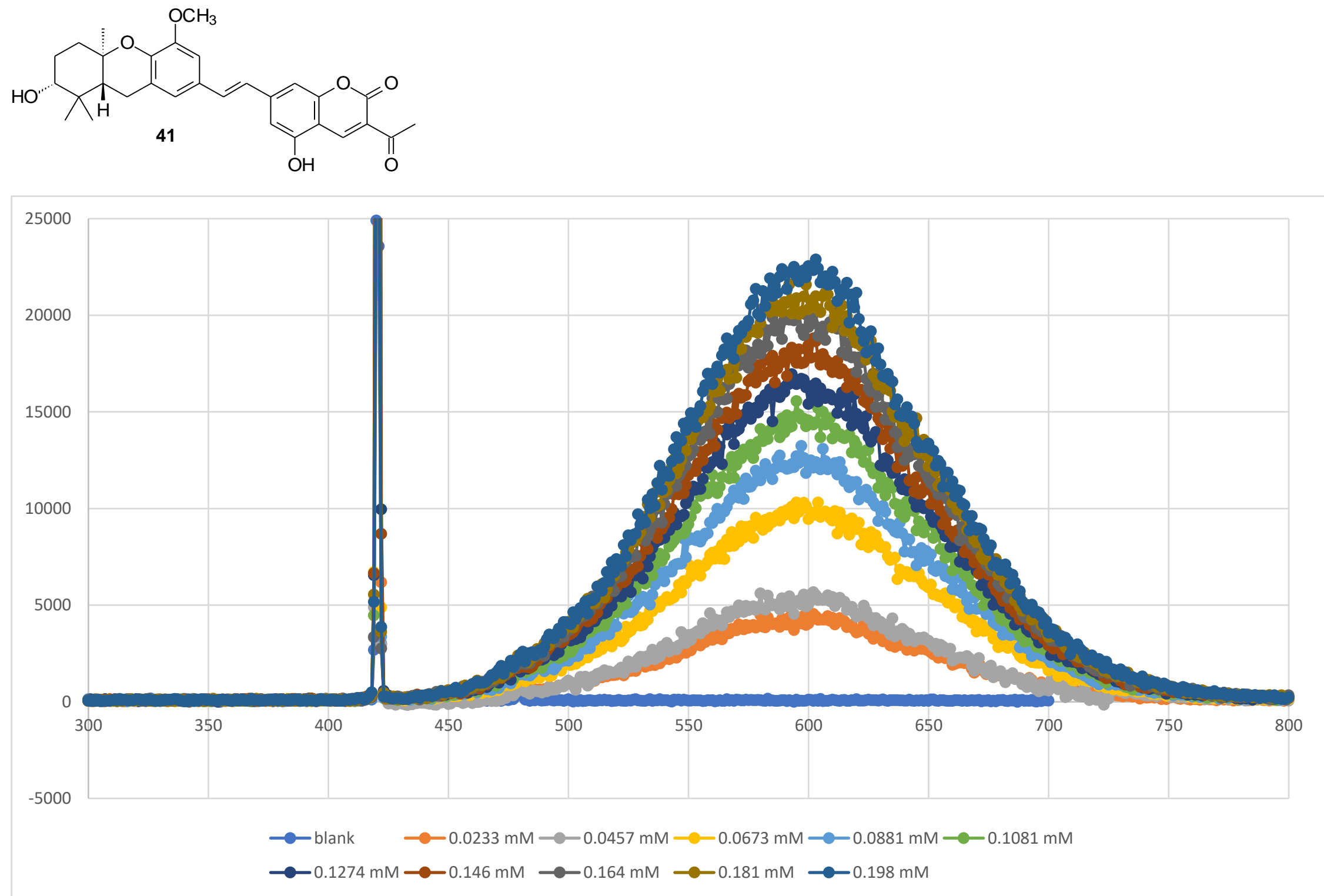

Emission spectrum of compound 41 in EtOH upon excitation at $420 \mathrm{~nm}$ 


\section{Dose Response Curves}

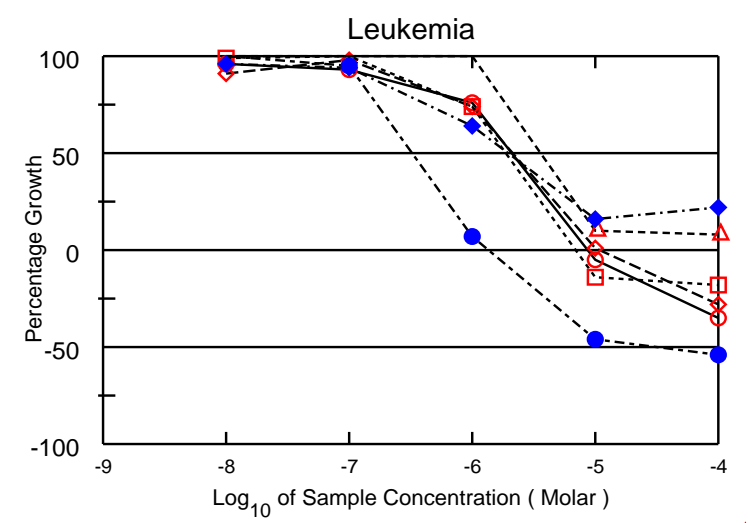

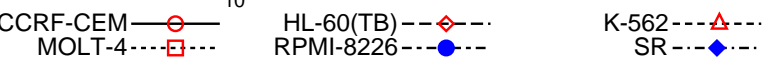

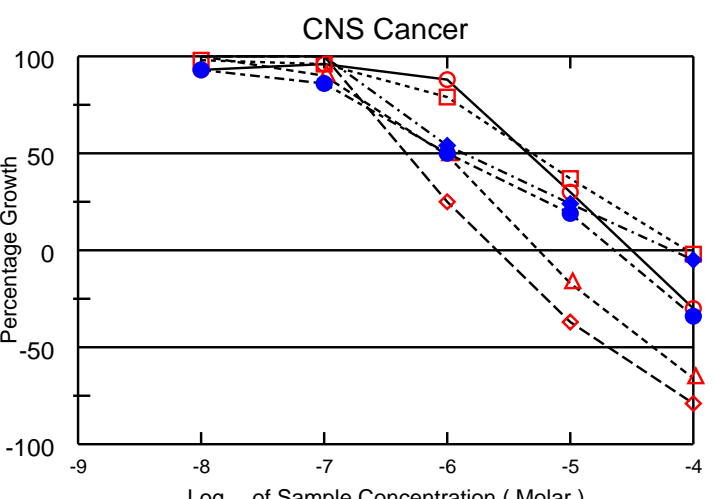

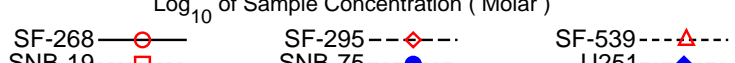
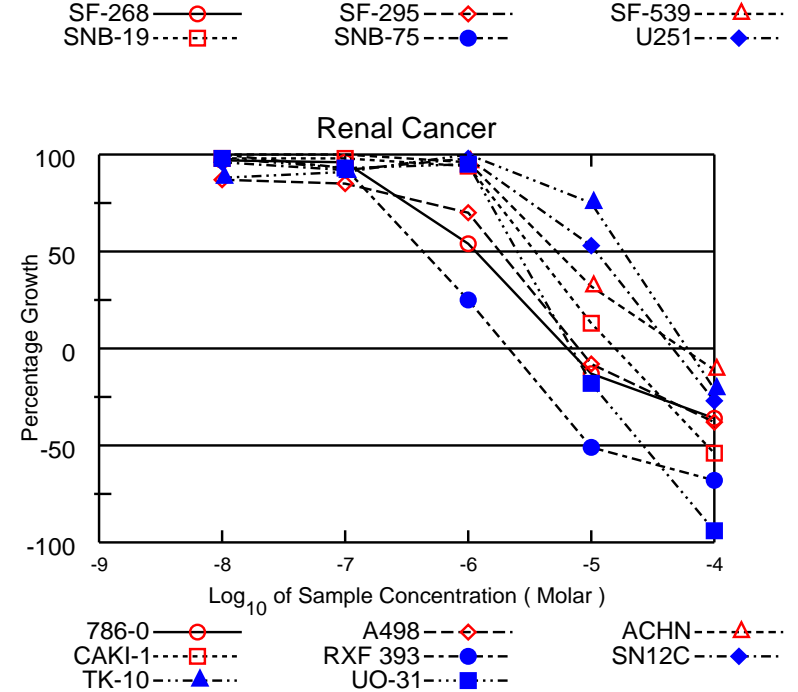

Report Date: December 11, 2020

Non-Small Cell Lung Cancer

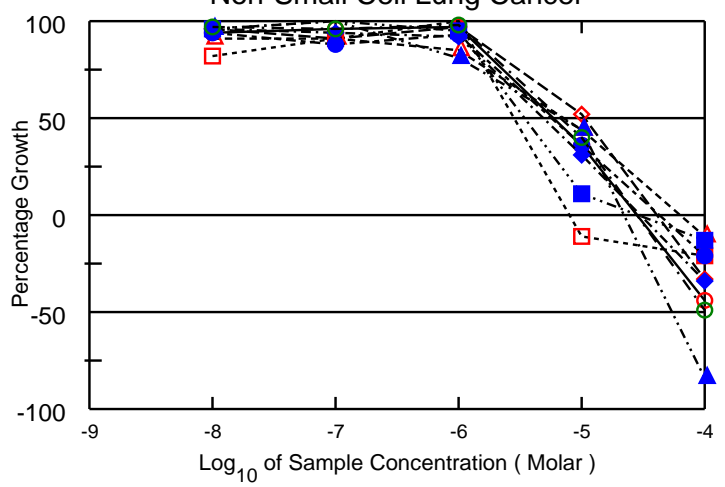

A549/ATCC —— EKVX--↔--. HOP-62---A-.

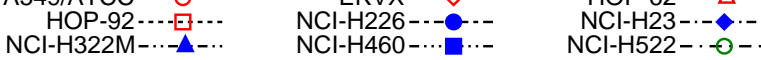

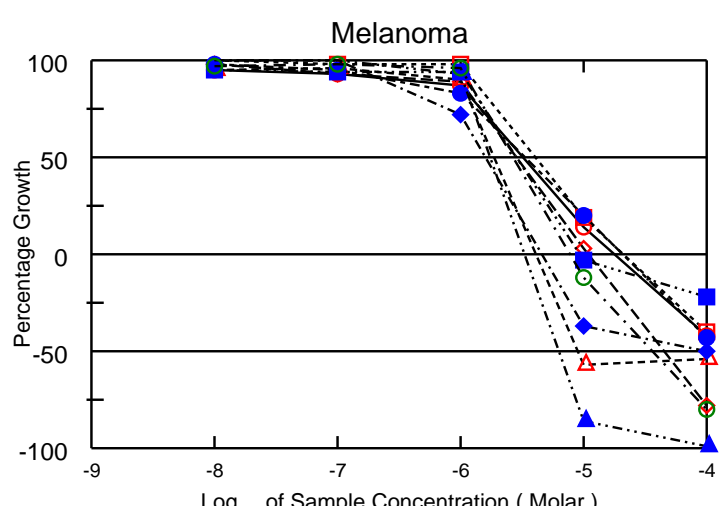

LOX IMVI-○— MALME-3M-- $\diamond--$.

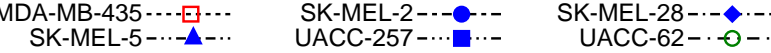

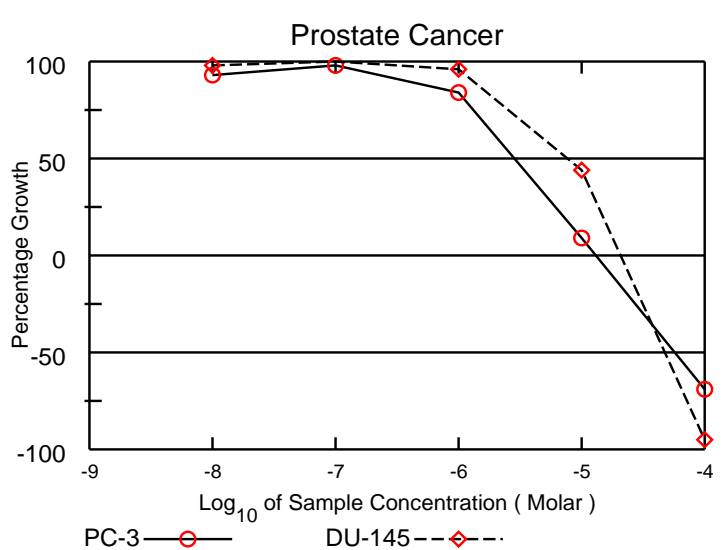

Test Date: November 16, 2020

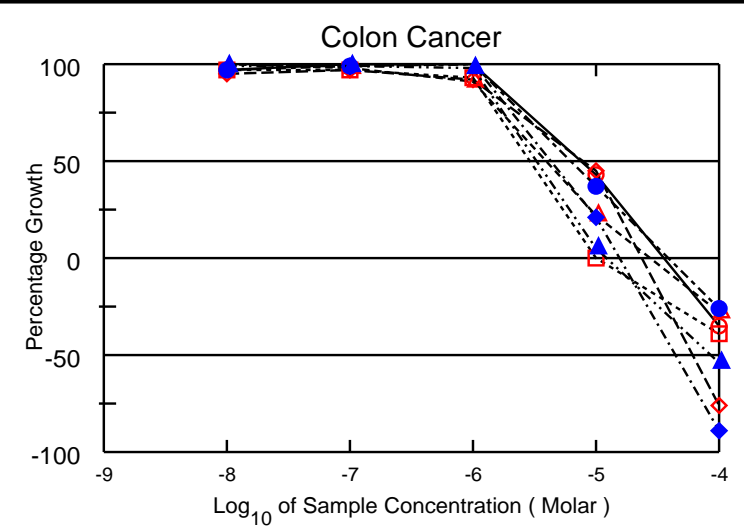

COLO 205-○- HCC-2998-- $\leadsto-$ HCT-116---A

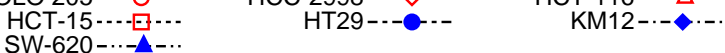

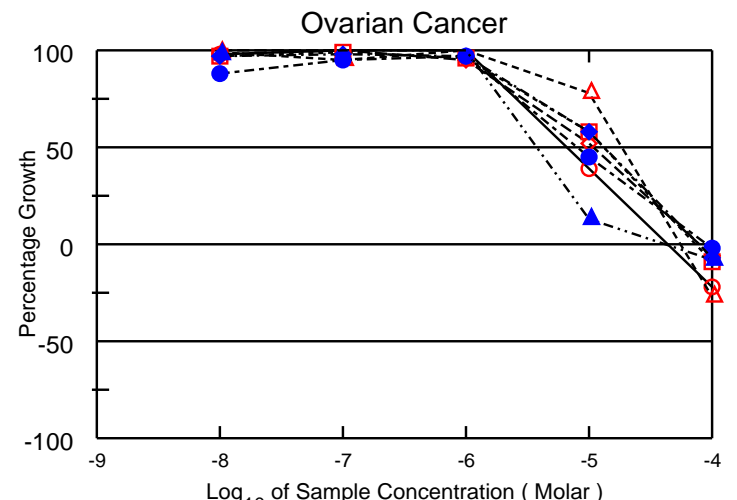

IGROV1 $1-0$ OVCAR-3-- $\rightarrow-$ OVCAR-4--- $A-$

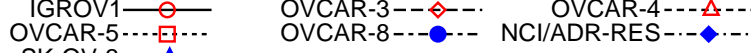
SK-OV-3-..-.

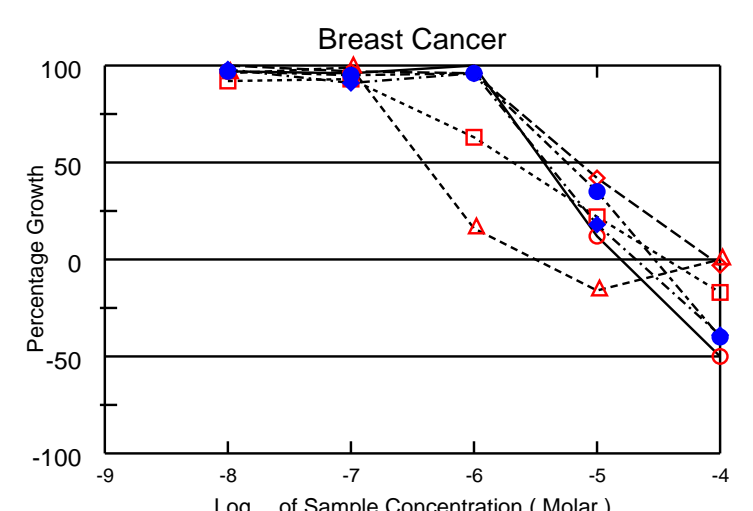

$\log _{10}$ of Sample Concentration ( Molar )

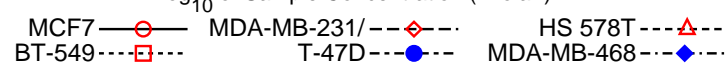


National Cancer Institute Developmental Therapeutics Program Mean Graphs

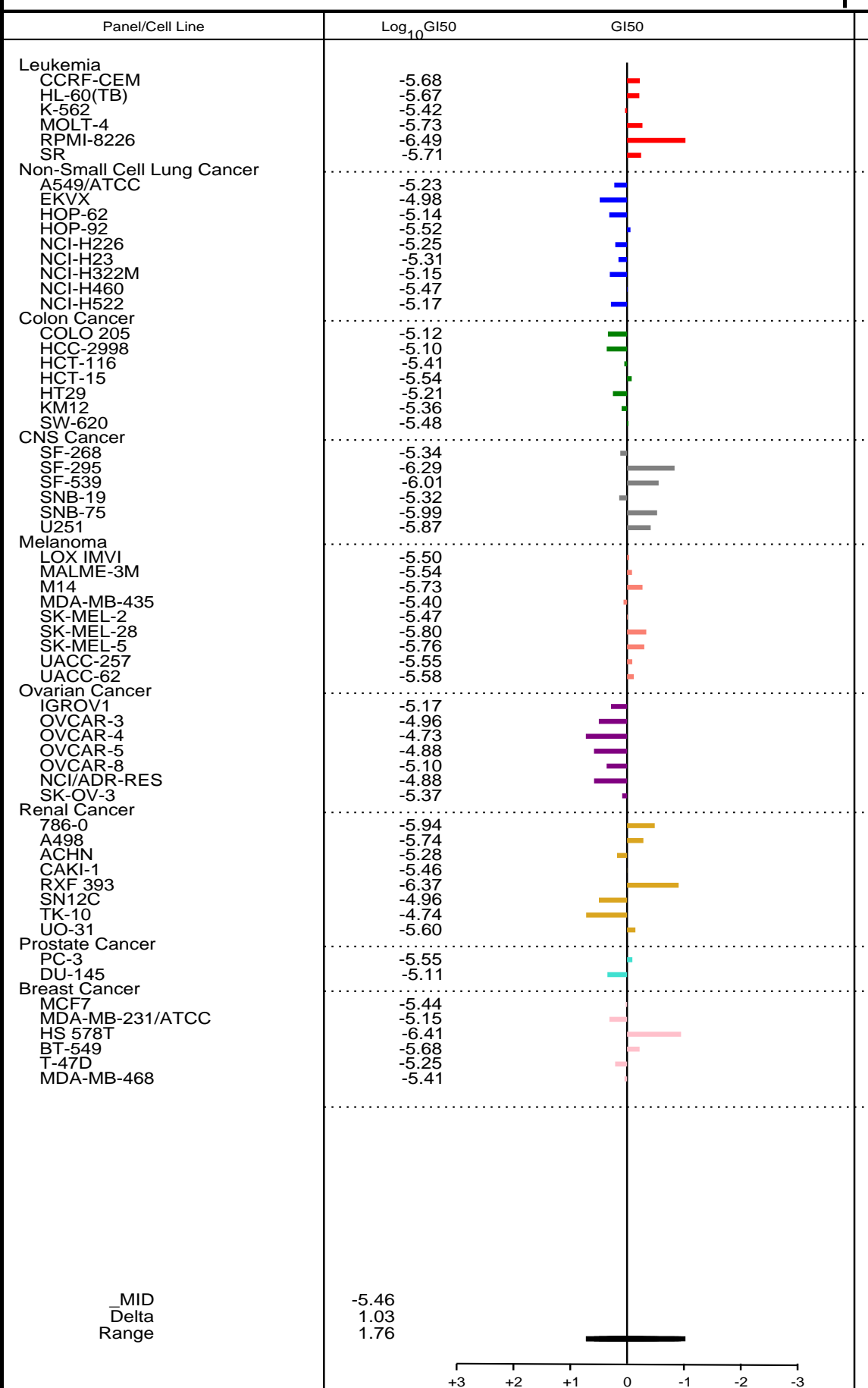

\begin{tabular}{|l|l|}
\hline NSC : D - 823234/1 & Units :Molar \\
\hline
\end{tabular}

Report Date :December 11, 2020

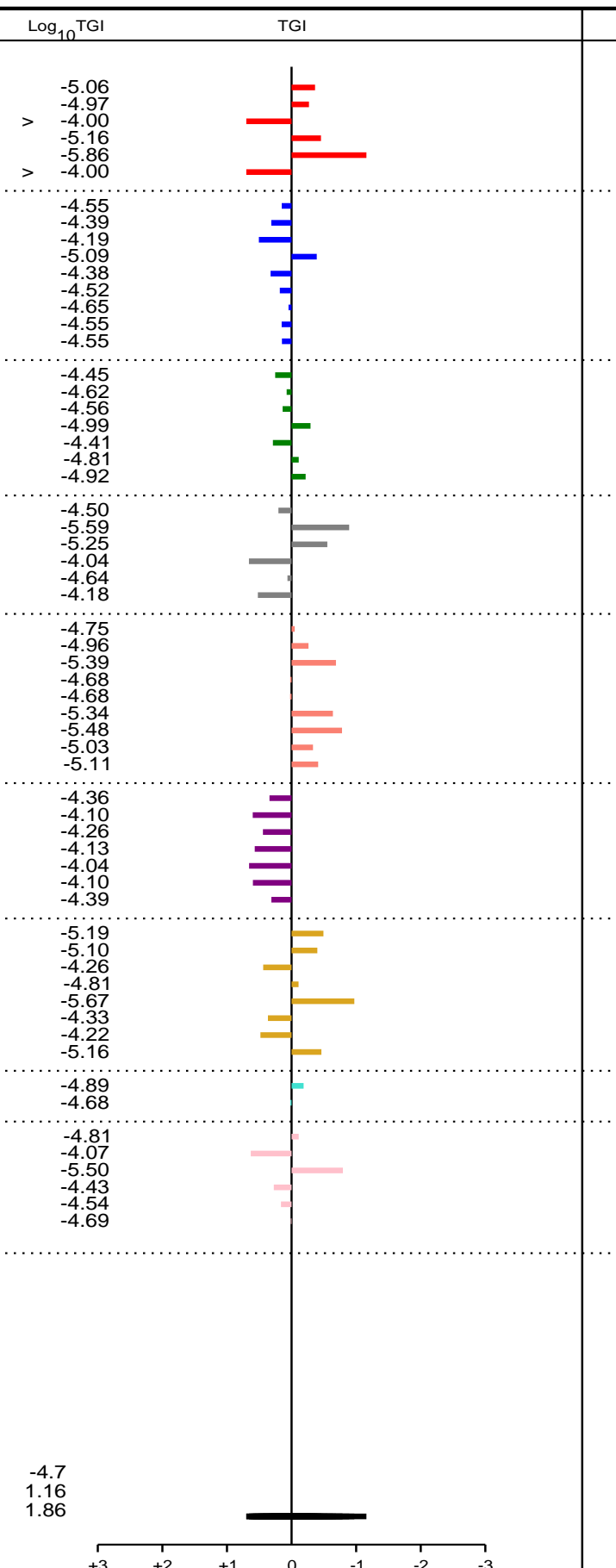

SSPL :0GZS

EXP. ID :2011RS62

Test Date :November 16, 2020

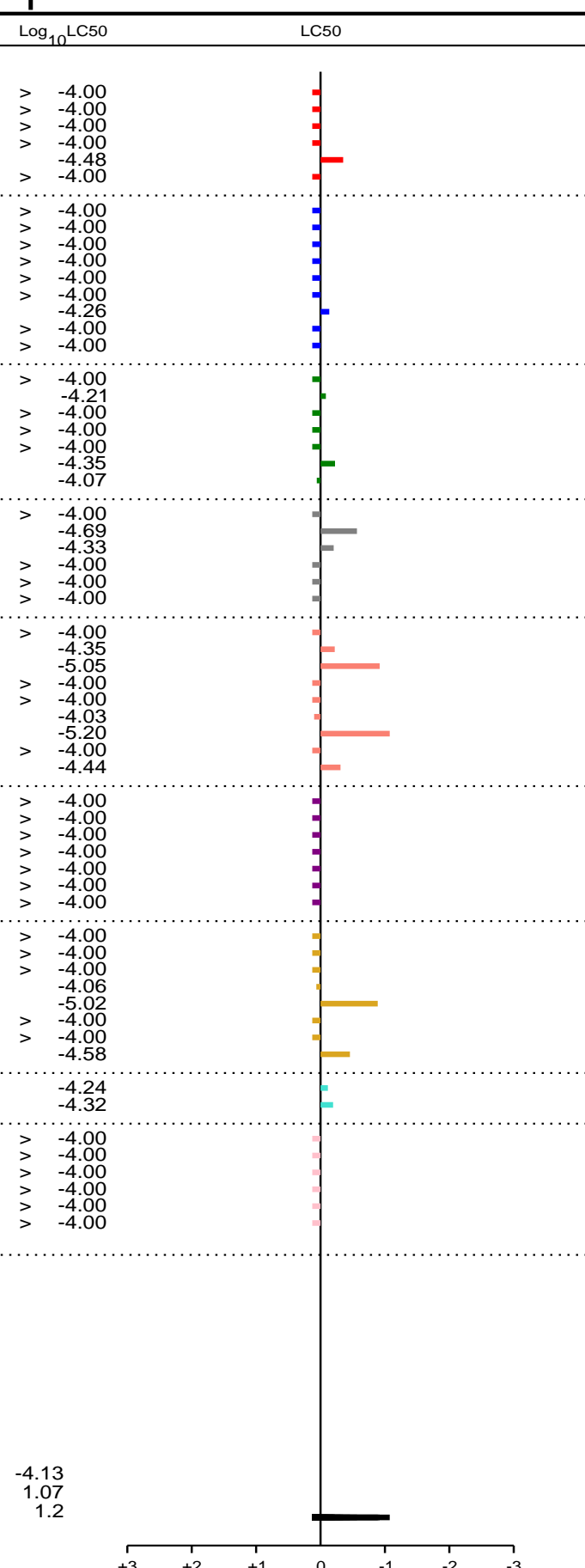


<smiles>CCOC(=O)CC(=O)CCC=C(C)C</smiles>

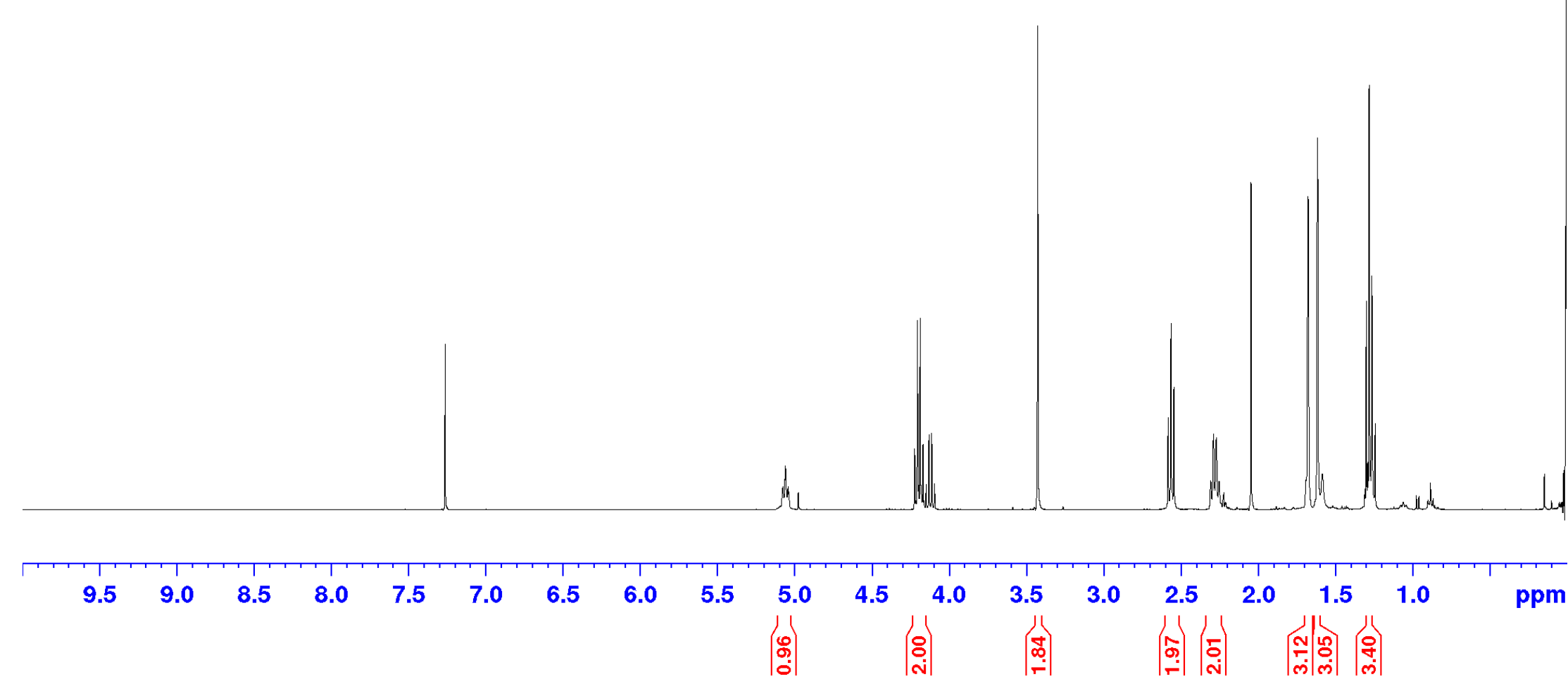

$400 \mathrm{MHz}{ }^{1} \mathrm{H}$ NMR spectrum of 42 in $\mathrm{CDCl}_{3}$ 

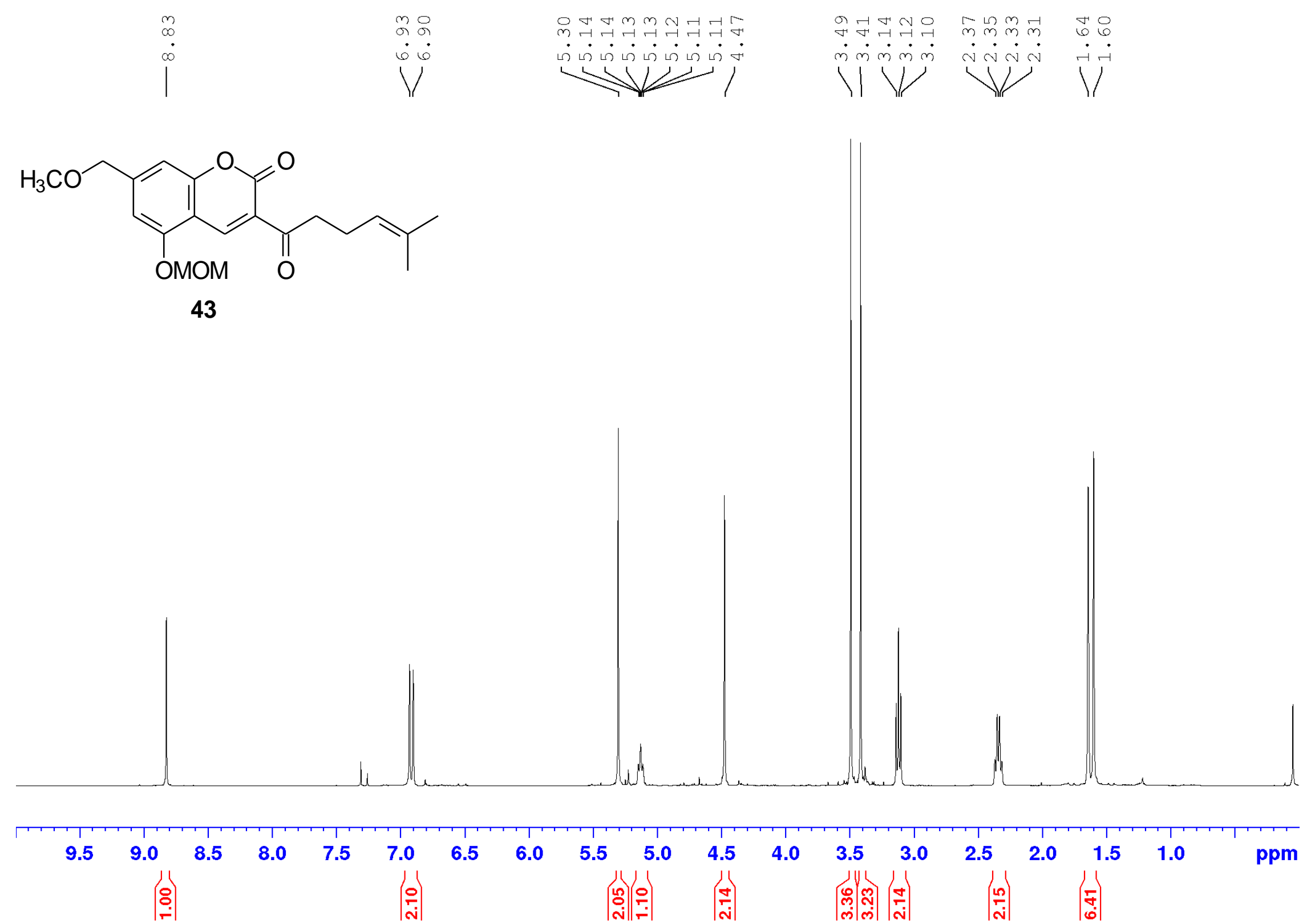

$400 \mathrm{MHz}{ }^{1} \mathrm{H}$ NMR spectrum of $\mathbf{4 3}$ in $\mathrm{CDCl}_{3}$ 

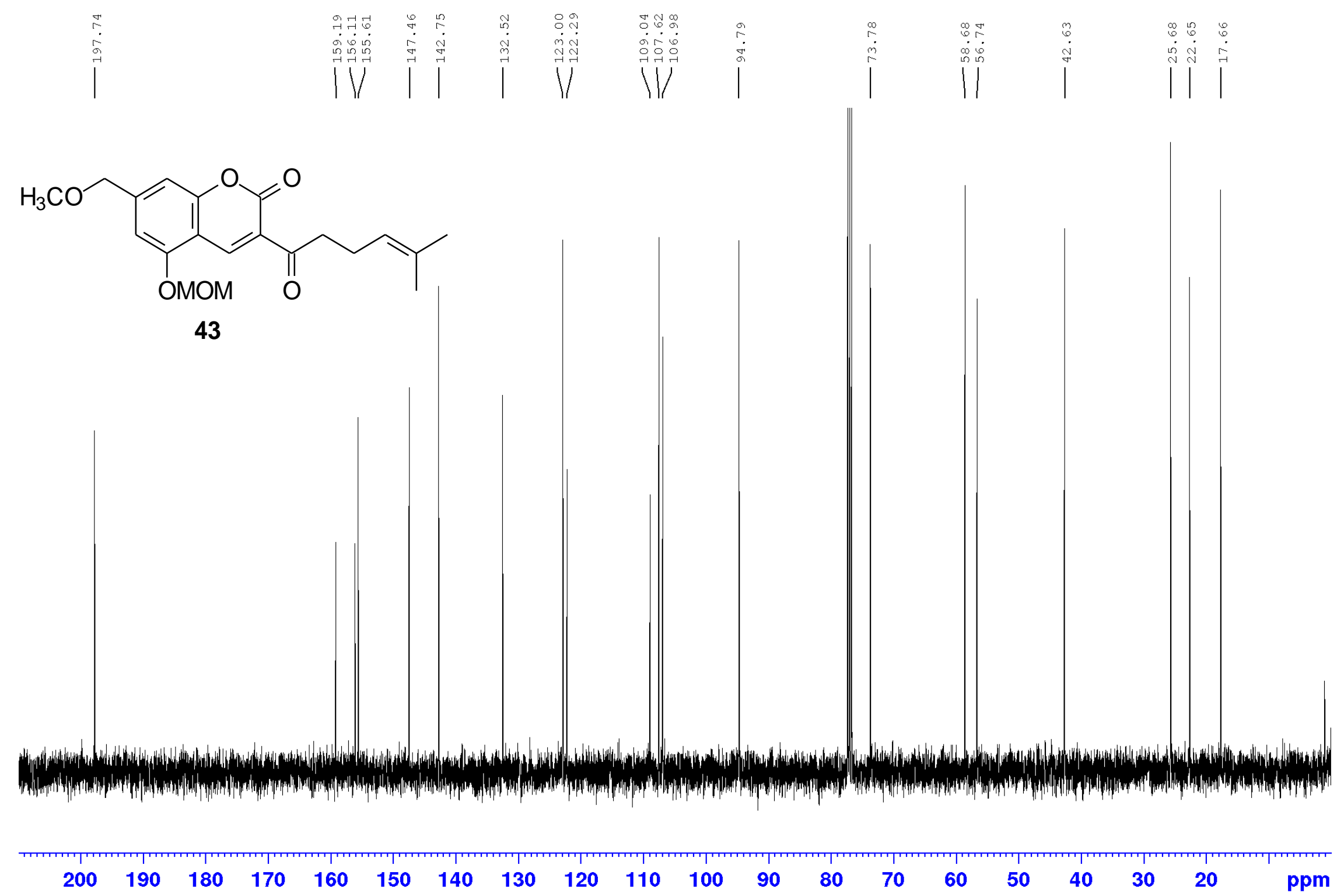

$100 \mathrm{MHz}{ }^{13} \mathrm{C}\left\{{ }^{1} \mathrm{H}\right\}$ NMR spectrum of 43 in $\mathrm{CDCl}_{3}$ 


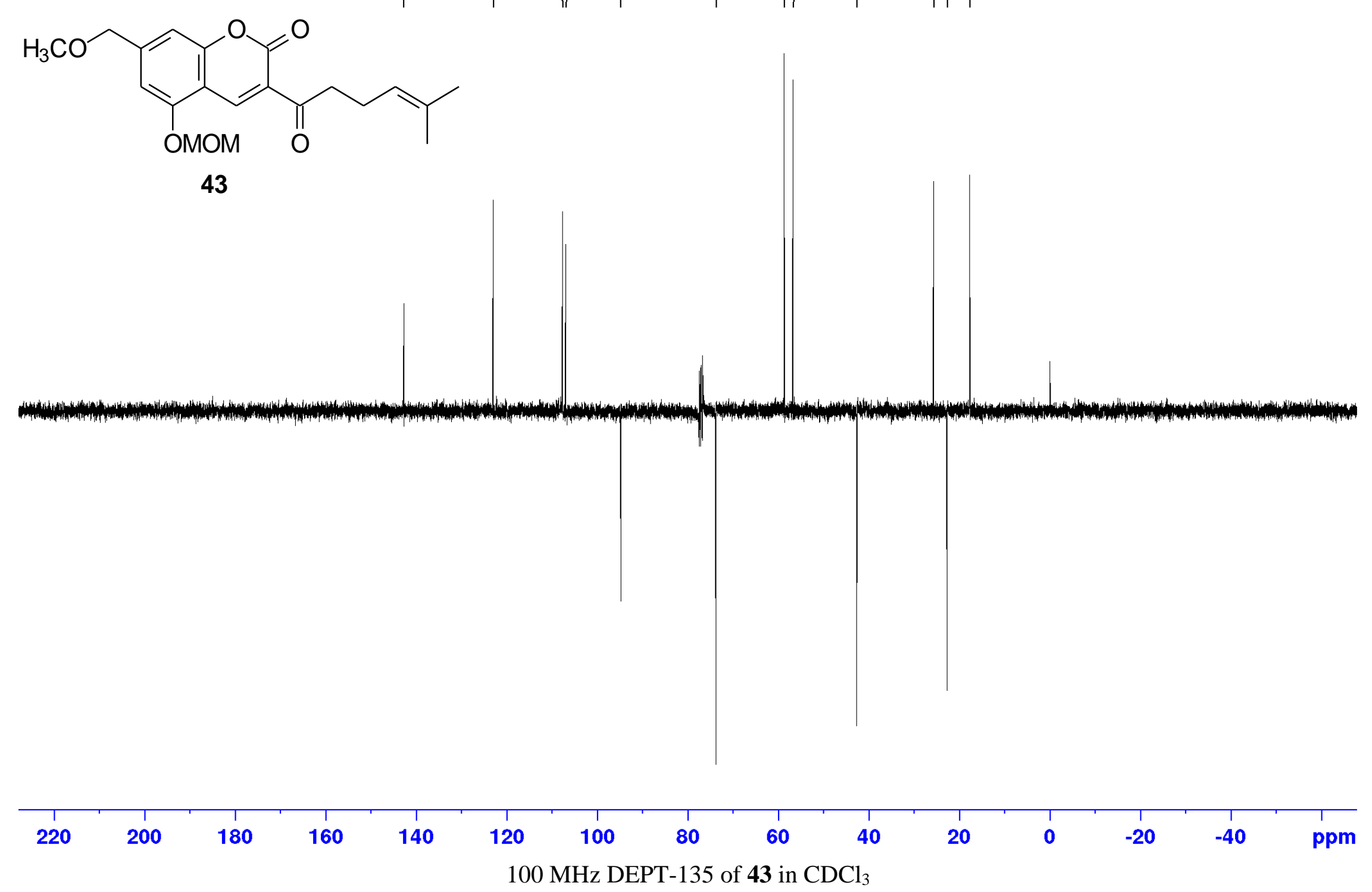



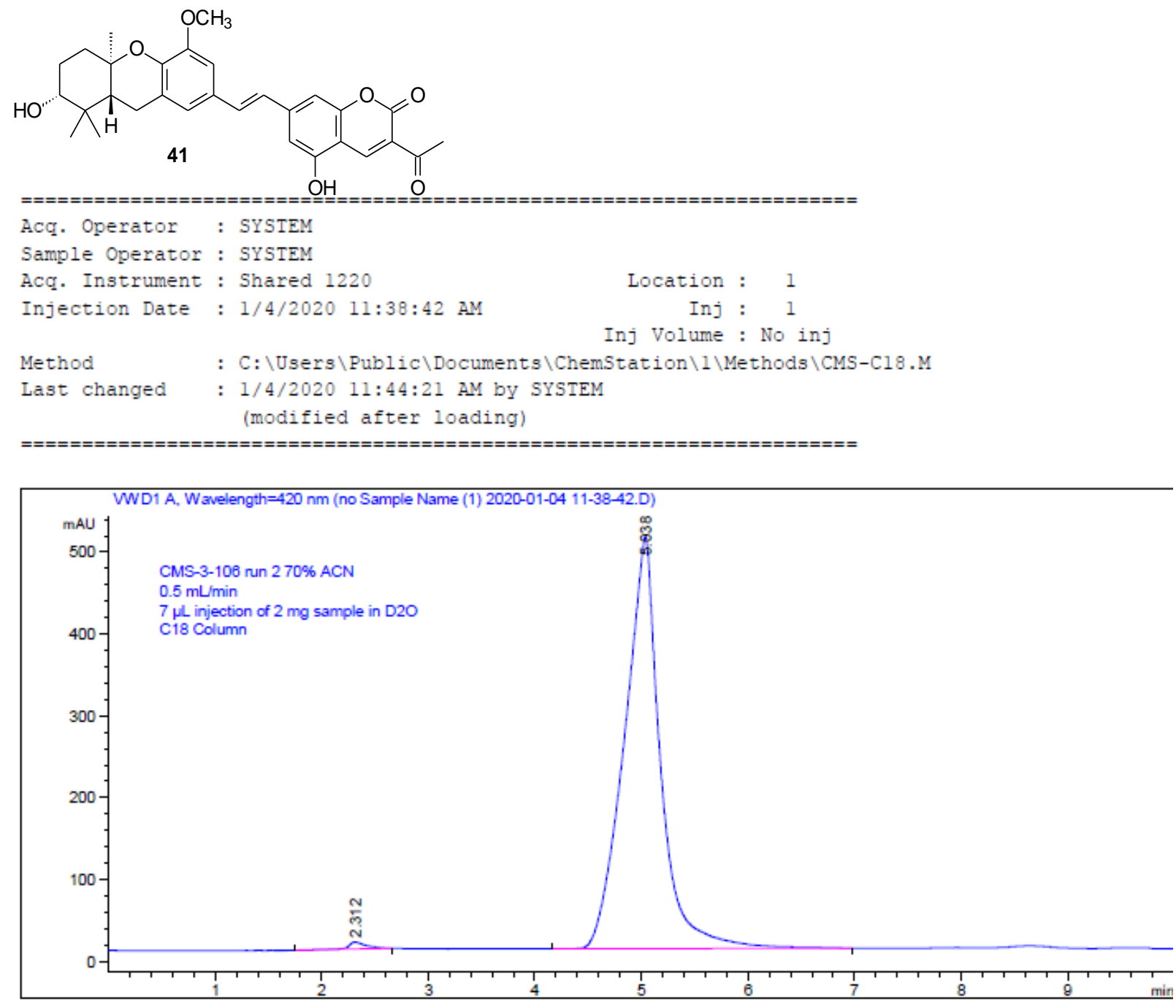

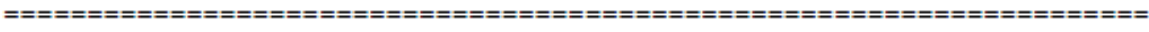

Area Percent Report

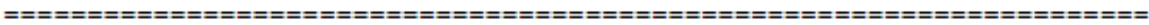

$\begin{array}{lll}\text { Sorted By } & : & \text { Signal } \\ \text { Multiplier } & : & 1.0000 \\ \text { Dilution } & : & 1.0000\end{array}$

Do not use Multiplier \& Dilution Factor with ISTDs

Signal 1: VWD1 A, Wavelength=420 nm

\begin{tabular}{|c|c|c|c|c|c|c|}
\hline $\begin{array}{c}\text { Peak } \\
\#\end{array}$ & $\begin{array}{c}\text { RetTime } \\
\text { [min] }\end{array}$ & Type & $\begin{array}{l}\text { Width } \\
\text { [min] }\end{array}$ & $\begin{array}{c}\text { Area } \\
{\left[\mathrm{mAU} \mathrm{U}^{*} \mathrm{~s}\right]}\end{array}$ & $\begin{array}{l}\text { Height } \\
{[\mathrm{mAU}]}\end{array}$ & $\begin{array}{c}\text { Area } \\
\frac{8}{8}\end{array}$ \\
\hline \multicolumn{7}{|c|}{ 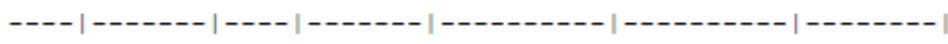 } \\
\hline 1 & 2.312 & $B B$ & 0.1650 & 105.00115 & 8.88003 & 0.8786 \\
\hline 2 & 5.038 & $B B$ & 0.3136 & $1.18456 \mathrm{e} 4$ & 503.35434 & 99.1214 \\
\hline otal & : & & & $1.19506 \mathrm{e} 4$ & 512.23437 & \\
\hline
\end{tabular}

HPLC trace of compound $\mathbf{4 1}$ 